\title{
Metabolism and functional effects of plant- derived omega-3 fatty acids in humans
}

\section{Article}

\section{Accepted Version}

Creative Commons: Attribution-Noncommercial-No Derivative Works 4.0

Baker, E. J., Miles, E. A., Burdge, G. C., Yaqoob, P. and Calder, P. C. (2016) Metabolism and functional effects of plantderived omega-3 fatty acids in humans. Progress in Lipid Research, 64. pp. 30-56. ISSN 1873-2194 doi:

https://doi.org/10.1016/j.plipres.2016.07.002 Available at https://centaur.reading.ac.uk/68680/

It is advisable to refer to the publisher's version if you intend to cite from the work. See Guidance on citing.

To link to this article DOI: http://dx.doi.org/10.1016/j.plipres.2016.07.002

Publisher: Elsevier

All outputs in CentAUR are protected by Intellectual Property Rights law, including copyright law. Copyright and IPR is retained by the creators or other copyright holders. Terms and conditions for use of this material are defined in the End User Agreement.

\section{www.reading.ac.uk/centaur}

\section{CentAUR}

Central Archive at the University of Reading 
Reading's research outputs online 


\section{Metabolism and Functional Effects of Plant-Derived Omega-3 Fatty Acids in Humans}

\section{Ella J. Baker ${ }^{1}$, Elizabeth A. Miles ${ }^{1}$, Graham C. Burdge ${ }^{1}$, Parveen Yaqoob ${ }^{2}$ and Philip C. Calder $^{1,3 *}$}

${ }^{1}$ Human Development and Health Academic Unit, Faculty of Medicine, University of Southampton, Southampton, United Kingdom

${ }^{2}$ Hugh Sinclair Unit of Human Nutrition, Department of Food and Nutritional Sciences and Institute for Cardiovascular and Metabolic Research, University of Reading, Reading, United Kingdom

${ }^{3} \mathrm{NIHR}$ Southampton Biomedical Research Centre, University Hospital Southampton NHS Foundation Trust and University of Southampton, Southampton, United Kingdom;

*Author for correspondence: Philip C. Calder, Human Development and Health Academic Unit, Faculty of Medicine, University of Southampton, IDS Building, MP887 Southampton General Hospital, Tremona Road, Southampton SO16 6YD, United Kingdom Phone: +44 2381205250

Email: pcc@soton.ac.uk

Key words: Alpha-linolenic acid, Stearidonic acid, Omega-3, Human health, Fatty acid composition

Abbreviations: AA, arachidonic acid; ALA, alpha-linolenic acid; CHD, coronary heart disease; $\mathrm{CHF}$, congestive heart failure; CRP, C-reactive protein; CVD, cardiovascular disease; D5D, delta-5-desaturase; D6D, delta-6 desaturase; DHA, docosahexaenoic acid; DPA, docosapentaenoic acid; EPA, eicosapentaenoic acid; GM, genetically modified; IL-6, interleukin-6; LA, linoleic acid; MUFA, monounsaturated fatty acid; NEFA, non-esterified fatty acid; PUFA, polyunsaturated fatty acid; RBC, red blood cell; RCT, randomised control trial; sICAM-1, soluble intercellular cell adhesion molecule-1; sVCAM-1, soluble vascular celladhesion molecule-1; SAA, serum amyloid A; SDA, stearidonic acid; SFA, saturated fatty acid; TAG, triacylglycerol; VLC, very long-chain; $\omega$-3, omega 3; WHO, World Health Organisation 


\section{Abstract}

Alpha-linolenic acid (ALA) is an essential fatty acid and the substrate for the synthesis of longer-chain, more unsaturated $\omega-3$ fatty acids, eicosapentaenoic acid (EPA), docosapentaenoic acid and docosahexaenoic acid (DHA). EPA and DHA are associated with human health benefits. The primary source of EPA and DHA is seafood. There is a need for sustainable sources of biologically active $\omega-3$ fatty acids. Certain plants contain high concentrations of ALA and stearidonic acid (SDA). Here we review the literature on the metabolism of ALA and SDA in humans, the impact of increased ALA and SDA consumption on concentrations of EPA and DHA in blood and cell lipid pools, and the extent to which ALA and SDA might have health benefits. Although it is generally considered that humans have limited capacity for conversion of ALA to EPA and DHA, sex differences in conversion to DHA have been identified. If conversion of ALA to EPA and DHA is limited, then ALA may have a smaller health benefit than EPA and DHA. SDA is more readily converted to EPA and appears to offer better potential for health improvement than ALA. However, conversion of both ALA and SDA to DHA is limited in most humans. 


\section{Introduction}

Epidemiological studies and several randomised control trials (RCTs) demonstrate a positive relationship between consumption of very-long chain (VLC) $\omega-3$ polyunsaturated fatty acids (PUFAs), specifically eicosapentaenoic acid (EPA; 20:5 $\omega-3$ ) and docosahexaenoic acid (DHA; 22:6w-3), and long term health benefits [1], including a reduction in cardiovascular disease (CVD) morbidity and mortality [2-8], better visual and neurological development [9] and improvements in inflammatory conditions including arthritis [10] and asthma [11]. However, it is important to note that not all RCTs report reduced mortality in patients with existing CVD when they receive supplemental EPA and DHA $[5,12,13]$. Reasons for these inconsistencies have been discussed elsewhere [14].

The beneficial effects of EPA and DHA that have been reported involve modification of the biophysical properties of cell membranes [15-18], changes in specific cell signalling pathways and altered gene expression $[19,20]$. The primary source of EPA and DHA is seafood especially oily fish, although they are found in lower amounts in many other foods of animal origin. The World Health Organisation (WHO), as well as many other authorities, recommends consumption of oily fish once or twice a week in order to assure dietary intake of VLC $\omega-3$ PUFAs with recognised health benefits [21]. However there are concerns about the sustainability of fish, and the current stocks of both farmed and wild fish are not likely to be sufficient to meet the needs of humans for VLC $\omega-3$ PUFAs $[22,23]$. This has increased the interest in the metabolism, functional effects and health benefits of $\omega$-3 PUFAs derived

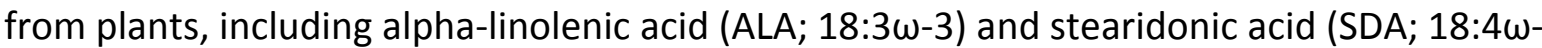
3).

Sources of ALA include green plant tissues, some nuts (e.g. walnuts), rapeseed oil (also known as canola oil), soybean oil (in which ALA contributes $10 \%$ of total fatty acids), and flaxseeds and flaxseed oil (in which ALA contributes $>50 \%$ of total fatty acids). ALA is the most abundant $\omega-3$ PUFA in the diets of people who do not regularly consume oily fish or take concentrated VLC $\omega-3$ PUFA supplements. Consumption of ALA in Europe, Australia and North America typically ranges from 0.6 to $2.3 \mathrm{~g} / \mathrm{d}$ in adult men and 0.5 to $1.5 \mathrm{~g} / \mathrm{d}$ in adult women [24-29]. Despite a higher dietary intake of ALA relative to EPA and DHA (approximately 25- and 15- fold greater [24]), concentrations of ALA within plasma and cell and tissue lipids are lower than those of EPA and DHA, apart from in adipose tissue stores. ALA is a metabolic precursor of EPA and DHA (Figure 1). The biosynthetic pathway includes a series of desaturation, elongation and beta-oxidation reactions, with the rate-limiting enzyme considered to be that catalysed by delta-6 desaturase (D6D) (Figure 1). However, it is also likely that there is regulation of other steps of the pathway, particularly the step involving translocation of 24:6w-3 into the peroxisome. The observation that ALA levels in blood, cells and most tissues are much lower than the levels of EPA and DHA indicates that the primary biological role of ALA may be as a substrate for EPA and DHA synthesis. However, evidence suggests that conversion of ALA to VLC $\omega-3$ PUFAs may be poor [30, 31], 
with conversion of ALA to EPA estimated at only 8 to $12 \%$ and to DHA much less at $1 \%$ [32]. This is discussed further in later sections.

ALA is one of the two essential fatty acids, the other being linoleic acid (LA; $18: 2 \omega-6)$. Essential fatty acid deficiency is very rare in humans and evidence to support ALA essentiality comes mainly from patients who received parental (intravenous) feeds lacking ALA. Visual dysfunction was reported in $50 \%$ of children and $30 \%$ of adults receiving longterm total parenteral nutrition lacking ALA [33]. DHA in neural membrane phospholipids modulates the activities of several signalling pathways in the brain [34, 35] and is critical for optimal retinal function [36, 37]. The lack of ALA provision decreases availability of DHA for incorporation into neural and retinal membranes and may explain the impact of ALA deficiency on vision [33].

SDA is an intermediate in the pathway of EPA and DHA biosynthesis (Figure 1), being the product of ALA desaturation by D6D. Since D6D is rate limiting for conversion of ALA to EPA, SDA is potentially a better substrate than ALA for the biosynthesis of VLC $\omega-3$ PUFAs. There are few natural sources of SDA; it is found in Echium oil, where it contributes about 9-16\% of fatty acids [38-40]. Levels of SDA have been substantially increased in soybean oil by genetic modification [41]. SDA levels in human blood, cells and tissues are normally very low.

This review discusses ALA and SDA as sources of $\omega-3$ PUFAs to promote increased levels of VLC $\omega$-3 PUFAs in human blood, cells and tissues and to provide the functional effects and health benefits of EPA and DHA. This review is based upon a previous article [42], but is broader in content and is updated.

\section{Alpha-linolenic acid and stearidonic acid consumption in different countries}

Typical intakes of ALA in adult Western populations are 0.5 to $2.3 \mathrm{~g} / \mathrm{d}$. Comparison between individual developed countries shows that average intake of ALA among adults has about a 3 -fold variation [29, 43, 44] (Table 1). For example, French adults consume an average of about $0.8 \mathrm{~g} / \mathrm{d}$ ALA, which is about one half to one third of the average intake of adults in Belgium, The Netherlands, Denmark, Finland and Germany (Table 1). The ratio of LA to ALA is important in determining relative rates of conversion of these precursor fatty acids to their long chain, more unsaturated derivatives (Figure 1) as discussed in detail later. There is substantial variation in the dietary LA: ALA ratio among different countries (Table 1). The average ratio is 2- to 4-times higher among Spanish, Portuguese, Italian and Greek adults than among adults in other countries listed in Table 1.

It is difficult to estimate the average dietary intake of SDA since there are few commonly consumed sources of this fatty acid and it is not usually included in nutrient databases. SDA is found in fish and other seafood, and some plants sources have been identified as being 
high in SDA. For example, seeds from members of the Boraginaceae family of plants, including the genera Borago (borage), Echium (e.g. Viper's bugloss) and Buglossoides (e.g. Corn gromwell) [45], contain SDA and the oils from those seeds contain approximately 15$22 \%$ of their fatty acids as SDA [45] (Table 2). A genetically modified (GM) soybean oil has been developed in which the SDA content has been enriched to $18-28 \%$ of total fatty acids $[46,47]$. Echium oil has a (naturally) lower content of SDA (approx. 12.5\%) than this transgenic oil (Table 2), but it is commercially available [48] and has been used in intervention studies where the effects of increasing intakes of SDA have been investigated. More recently, Corn gromwell which is naturally rich in SDA, has been explored as a higher yielding commercial crop [48].

\section{Bioavailability of alpha-linolenic acid and stearidonic acid from the diet}

ALA absorption across the gut and its release into the bloodstream appear to be efficient in healthy humans. After ingestion of a single meal containing ${ }^{2} \mathrm{H}$-labelled fatty acids, concentrations within the triacylglycerol (TAG) fraction of chylomicrons were measured. The

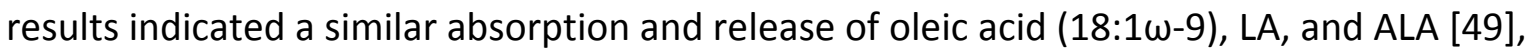
suggesting that bioavailability of ALA from a meal is comparable to that of other unsaturated fatty acids. In another study where patients with ileostomies were fed $100 \mathrm{~g}$ linseed oil, ALA was absorbed with $98 \%$ efficiency [50]. It is unlikely that SDA bioavailability would be limited in healthy people, although this has not yet been studied.

\section{Alpha-linolenic acid and stearidonic acid metabolism in humans}

\subsection{Metabolic fates of alpha-linolenic acid}

In common with other long chain fatty acids, ALA which has been absorbed from the gut passes into the circulation primarily esterified into TAG carried by chylomicron particles. Chylomicron TAG are hydrolysed by lipoprotein lipase expressed on the endothelium; adipose tissue lipoprotein lipase is upregulated in the post-prandial period which results in targeting of meal fatty acids for storage. As a result of this TAG hydrolysis, TAG-poor chylomicron remnants are formed. These are cleared from the circulation largely by hepatic receptor-mediated uptake. The fatty acids from the chylomicron remnants are processed in the liver and may re-appear in the bloodstream as components of TAG (in very low density lipoproteins) or phospholipids. Through these processes ALA from the diet can be made available to be incorporated into cell membranes and pools for storage (mainly in adipose tissue), energy production (many cell and tissue types) or conversion to longer-chain $\omega-3$ PUFAs (this is believed to mainly occur in the liver). The metabolic fates of ALA are summarised in Figure 2 and each fate is discussed in further detail below.

\subsubsection{Incorporation of alpha-linolenic acid into adipose tissue}

ALA is the most abundant $\omega-3$ PUFA in human adipose tissue, accounting for approximately $1 \%$ of total fatty acids, while there are only trace amounts of DHA and EPA [51, 52]. During the postprandial period there is metabolic drive to store fatty acids which is facilitated by a 
local increase in lipoprotein lipase activity and enhanced fatty acid uptake into adipose tissue and up-regulation of TAG synthesis. During the fasting state, hormone sensitive lipase hydrolyses adipose tissue TAG stores with the released fatty acids appearing in plasma as non-esterified fatty acids (NEFAs). When men consumed [U- $\left.{ }^{13} \mathrm{C}\right] A L A$ it was detected within the plasma NEFA pool after only $2 \mathrm{~h}$ and peaked at $6 \mathrm{~h}$ [30], indicating rapid release of nonesterified ALA possibly from chylomicron TAG. This could be due to lack of entrapment of the released ALA at the adipose tissue level, which could be a mechanism to facilitate supply of ALA to the liver. Heath et al. also demonstrated lack of entrapment of both EPA and DHA: they found that EPA in the NEFA pool was half of that in the meal given, and DHA was twice of that in the meal given, indicating less DHA is taken up into the adipose tissue compared to EPA [53].

Twenty one days after consuming the meal, the concentration of non-esterified $\left[{ }^{13} \mathrm{C}\right] \mathrm{ALA}$ in the fasting state was 2 -fold greater in young women (mean age 28 years) than in men (age range 27 to 40 years) [30, 31]. This suggests that there may be differences in ALA metabolism and storage between men and women, but this has not been explored across a range of ages so it is not clear if the sex differences seen in young adults are also apparent in children, adolescents and older adults.

Storage within adipose tissue is an important disposal route of dietary ALA [54]. The higher percentage of adipose tissue in women (average of $23 \%$ of body mass compared to $15 \%$ in men [42]) may suggest the storage of ALA in women is greater than in men. Table 3 provides an approximate calculation of total adipose tissue ALA content in normal weight men and women using an adipose tissue ALA proportion of $1 \%$ for both sexes. This results in an estimated ALA content of $97 \mathrm{~g}$ for men and $112 \mathrm{~g}$ for women (Table 3). This estimate would be affected by differences in dietary ALA intake, in body fatness, in the ALA content of different adipose depots, and in metabolism between individuals. However, our estimate indicates that there may be little difference in total adipose tissue stores of ALA between men and women, indicating that storage of dietary ALA in adipose tissue would not be a factor limiting hepatic conversion of ALA to EPA.

\subsubsection{B-oxidation of alpha-linolenic acid}

ALA has been shown to have the highest rate of $\beta$-oxidation among the unsaturated fatty acids tested [55]. Studies using tracers report that conversion of ALA to carbon dioxide via $\beta$-oxidation over the first hours following its consumption accounts for $15-35 \%$ of ALA consumed [30, 31, 54, 56, 57]. McCloy et al. followed ALA $\beta$-oxidation for 7 days following consumption of labelled ALA and showed a progressive increase in appearance of labelled $\mathrm{CO}_{2}$ which accounted for $\sim 70 \%$ of dietary ALA over a seven day period [54]. In comparison, LA oxidation at 9 hours after consumption accounted for $12 \%$ of the LA consumed and at 7 days after consumption $\sim 40 \%$ of LA consumed [54]. 


\subsubsection{Recycling of carbon from a-linolenic acid into saturated and monounsaturated fatty}

acids

During mitochondrial $\beta$-oxidation of ALA, carbon units generated in the form of acetyl-CoA can be recycled to synthesize saturated fatty acids (SFAs), monounsaturated fatty acids (MUFAs), cholesterol and ketone bodies [56]. Burdge and Wootton measured concentrations of labelled saturated and monounsaturated fatty acids in men and women over $21 \mathrm{~d}$ after consumption of $700 \mathrm{mg}\left[\mathrm{U}-{ }^{13} \mathrm{C}\right] \mathrm{ALA}$. Labelled palmitic, stearic, palmitoleic and oleic acids were detected in plasma phosphatidylcholine (PC) and TAG [58]. There was greater incorporation of label from ALA into plasma PC than into TAG in both men and women. This difference in incorporation of label from ALA into plasma PC and TAG was 6fold in men and 25-fold in women. These findings suggest favourable channelling of SFA and MUFA synthesised from ALA by the recycling pathway into phospholipids by the liver in both men and women. This is in contrast to the molecular partitioning of the bulk of the hepatic SFA and MUFA pools which is towards TAG [42]. This recycling of carbon from ALA may be an important route for metabolism of ALA that is not required for EPA and DHA synthesis, or oxidised or stored in adipose tissue.

\subsection{Metabolic fates of stearidonic acid}

There are no tracer-based studies of SDA metabolism.

\subsection{The pathway of conversion of alpha-linolenic acid and stearidonic acid to longer-chain polyunsaturated fatty acids}

\subsubsection{Overview of the pathway}

ALA and SDA are converted to EPA and DHA through a series of elongation and desaturation processes occurring predominantly within the endoplasmic reticulum, excluding the last $\beta$ oxidation reaction which forms DHA and occurs in peroxisomes (Figure 1). This pathway is believed to mainly occur within the liver [59], but there is some evidence that brain, retina and testis also have high expression of the genes encoding the relevant enzymes compared with other tissues $[60,61]$. Competition exists between the conversion of $\omega-6$ and $\omega-3$ fatty acids as both utilise this same metabolic pathway. The initial conversion of ALA to SDA is catalysed by D6D and is considered to be the rate limiting reaction in the pathway $[62,63]$. D6D is encoded by the gene fatty acid desaturase 2 (Fads2) and has a preference for ALA over LA: the $\mathrm{Km}$ of rat D6D for ALA is between 29 and $33 \mu \mathrm{M}$ while the $\mathrm{Km}$ for LA is between 43 and $92 \mu \mathrm{M}$ [64]. However, when there is much greater availability of LA than ALA the metabolism of the former exceeds that of the latter. The D6D reaction results in insertion of a double bond at the delta- 6 position of ALA to form SDA. SDA is converted to 20:4 $\omega-3$ by the addition of 2 carbons by the enzyme elongase- 5 , encoded by fatty acid elongase 5 (Elov/5). 20:4 $\omega-3$ is then converted to EPA by insertion of a double bond at the delta-5 position by delta-5-desaturase (D5D), which is encoded by the gene fatty acid desaturase 1 (Fads1). EPA can be elongated by elongase 2 (encoded by Elov/2) or elongase 5 to form 
docosapentaenoic acid (DPA; 22:5 $\omega-3$ ) and then DPA is elongated by elongase 2 to yield $24: 5 \omega-3$. The subsequent desaturation of $24: 5 \omega-3$ to $24: 6 \omega-3$ again uses a D6D activity, that seems to involve the same D6D as in the first step of the pathway [59]. This is evidenced by the observations that skin fibroblasts from a patient with D6D deficiency were unable to desaturate either LA or 24:5w-3 [65] and that rat D6D was able to desaturate both ALA and $24: 5 \omega-3$ [66]. 24:5 $\omega-3$ is then translocated to the peroxisome where it undergoes one round of $\beta$-oxidation to form DHA $[63,67,68]$. Recent mechanistic studies suggest conversion of EPA to DHA may be limited by the second product of Elov/2 (24:5w-3) [69]. This suggests that understanding the action and regulation of Elov/2 may be critical in understanding DHA synthesis.

SDA is an intermediate in this metabolic pathway, being synthesised from ALA via the action of D6D (Figure 1). EPA biosynthesis from SDA is considered to be more efficient than that from ALA due to it not requiring this first catalytic step, and SDA has been referred to as 'pro-EPA' because of this enhanced conversion [70].

\subsubsection{Genetic and epigenetic influences on the conversion pathway}

The activity of the PUFA biosynthesis pathway is differentially regulated by dietary fatty acids at the level of transcription of Fads1 and Fads2, the genes which encode D5D and D6D, respectively [71]. Such regulation appears to involve activation of peroxisome proliferator activated receptors and sterol response element binding protein-1c [72]. Active response elements have been identified in Fads2 for both of these transcription factors [72]. One implication of these findings is that capacity for conversion of ALA to longer chain metabolites may modified by genetic and/or epigenetic processes which influence the transcription of the Fads genes. In humans, Fads genes are located in head to head (Fads 1 and 2) and tail to tail (Fads 2 and 3) orientations on chromosome 11 [73]. This suggests the possibility of coordinated changes in gene expression by mutations or epigenetic changes in shared sequences.

\subsubsection{Genetic influences on the conversion pathway}

A number of single nucleotide polymorphisms (SNPs) have been identified in Fads1 and Fads2, some of which have been associated with differences in $\omega-3$ and/or $\omega-6$ PUFA status [71-93]. In general, minor alleles of both Fads1 and Fads2 have been shown to be associated positively with essential fatty acid status, but negatively with longer chain PUFA status (Table 4). This suggests that these polymorphisms impair the activity of the gene or the encoded enzyme, although there is limited direct evidence to support such effects. A SNP ( $r$ 968567) in Fads2, which has been associated with lower concentrations of longer chain PUFAs [74] has been shown to create response elements for STAT 1 and 3, and ELK-1, and to increase ELK-1 binding to this region [75]. In addition, incubation of lymphocytes with simvastatin was associated with 20 to $40 \%$ greater expression of Fads 2 and Fads 1 compared to cells containing the minor alleles of SNPs associated with a SREBP response 
element to the major alleles [76]. Insertion-deletion mutations proximal to the SREBP-1C response element also modified response to simvastatin [76]. These findings provide proofof-principle evidence that at least some SNPs in the 5'-regulatory region of Fads 2 can alter the level of transcription. SNPs in Elov/2, which encode elongases 2, have also been shown to alter longer chain PUFA status. Minor alleles of SNPs in Elov/2 have been associated with lower DHA [77] and EPA [78] status. In addition, a SNP in Elov/5 has been shown to be associated with lower capacity to convert EPA to DPA [91] . Overall, these findings show that minor alleles of SNPs in genes encoding fatty acid desaturase or elongase genes are associated with lower status of LC PUFAs. However, the absolute differences in proportions of individual fatty acids between individuals bearing different genotypes tend to be relatively small and there are no studies to date that have linked such differences to altered cell function. Such studies are important in order to know which polymorphisms, if any, need to be considered when making recommendations for consumption of ALA, EPA and DHA.

\subsubsection{Epigenetic influences on the conversion pathway}

There is emerging evidence that the expression of genes involved in PUFA biosynthesis can be modified by changes in the epigenetic regulation, although to date this evidence has been obtained largely from studies in animal models. Homocysteine concentration has been shown to be associated positively with the methylation of $\mathrm{CpG}$ loci in the Fads2 promoter of mice [79]. Increasing the proportion of ALA to LA in the diet of pregnant mice increased the average DNA methylation of the Fads2 promoter, but not intron 1, in the liver by $1 \%$ to $2 \%$ which was negatively associated with the level of the mRNA transcript [80]. Feeding female rats diets containing either $3.5 \%$ (low fat), $7 \%$ (adequate fat) or $21 \%$ (high fat) fat $(w / w)$ enriched in either saturated and monounsaturated fatty acids derived from butter or in EPA and DHA derived from fish oil reduced the proportion of AA in the liver of the adult offspring irrespective of the type of fat consumed [81]. There was no effect of maternal fat intake on Fads1 promoter methylation or its mRNA expression. However, there was a positive relationship between maternal dietary fat content and the methylation of specific CpG loci in the 5'regulatory region of Fads2 in the liver of the adult offspring irrespective of the type of fat consumed. This was associated negatively with Fads2 mRNA expression. Mutation of a $\mathrm{CpG}$ located -394 bp from the Fads 2 transcription start site within a putative estrogen response element induced lower transcriptional response to estrogen compared to the wild type promoter. This suggests that this $\mathrm{CpG}$ is involved in the regulation of Fads2 expression [82]. Feeding pregnant rats diets containing $7 \%$ or $21 \%(\mathrm{w} / \mathrm{w})$ safflower oil, hydrogenated soybean oil, fish oil or soybean oil also induced increased Fads2 methylation and decreased its expression in aorta from the adult offspring. However, the magnitude of change was related to the type of oil consumed by the dam [82]. Thus, induction of differential changes in methylation by different fatty acids may be tissuedependent. Feeding adult rats a fish oil-enriched diet for 9 weeks induced reduced Fads 2 mRNA expression and increased methylation of CpG loci in the 5 'regulatory region of Fads 2 
compared to those fed soybean oil [81]. However, these changes were reversed in rats that were switched from fish oil to soybean oil. These findings suggest that that persistence of changes in DNA methylation induced by dietary fat is contingent on the period of exposure during the life course.

There is some evidence that DNA methylation also modifies fatty acid desaturase activity in humans. Higher methylation of CpG loci in the intergenic region between the Fads1 and 2 genes was associated with lower expression of D5D and, to a lesser extent, D6D in human liver [83]. Furthermore, patients who had attempted suicide showed a trend toward lower CpG methylation within a region of Fads2 upstream of the transcription start site and higher methylation in a region upstream of the Elovl5 transcription start site compared to controls [94]. Such differences were not associated with statistically significant variation in plasma EPA and DHA concentrations after correction for age and sex. However, since astocytes and glial cells, but not neurones, are able to synthesise LC PUFAs [95], it is possible that these polymorphisms may have had a significant effect on PUFA concentrations locally within the brain. Methylation of one CpG locus in Fads2 in blood has been shown to be related negatively to delayed memory performance in young children [84]. Furthermore, moderate intake of EPA and DHA ethyl esters has been shown to induce altered methylation of CpG loci within the 5'-regulatory regions of Fads2 and Elov/5, but not Fads1 and lovl2, in peripheral blood mononuclear cells from patients with mild renal impairment compared to individuals who consumed the same amount of olive oil [85]. However, the magnitude, direction and loci affected differed between men and women. These findings were replicated for the omega-3 ethyl ester supplement in healthy volunteers. This suggests that induced changes in DNA methylation may be one mechanism by which omega-3 dietary supplements can alter immune function. This is supported by the observation that immune response is impaired in Fads2 null mice [96].

\subsection{Conversion of alpha-linolenic acid and stearidonic acid to longer-chain PUFAs in humans}

Knowledge of the extent to which humans can convert ALA and SDA to longer-chain PUFAs is based on short term studies with stable isotopes and longer term studies involving increased consumption of the fatty acids. As explained above, the biosynthesis of longerchain $\omega-3$ PUFAs from SDA is considered to be more efficient than from ALA due to it not requiring the rate limiting step catalysed by $D 6 D$ and studies which have directly compared consumption of SDA to that of ALA have shown a greater increase of EPA in blood lipids and cells than seen for ALA consuming subjects, although no significant changes in plasma or red blood cell (RBC) DHA levels were observed [97-100].

The conversion of ALA to both EPA and DHA appears to be more efficient in women than in men. In men, conversion of ALA to EPA has been reported to be between $0.3 \%$ and $8 \%$, and conversion to DHA $<1 \%$, whereas in women up to $21 \%$ conversion to EPA and up to $9 \%$ 
conversion to DHA have been reported [101]. It has been suggested that the higher rate of conversion in women may be because of their greater requirement to produce VLC $\omega-3$ PUFAs during pregnancy and lactation [102].

In studies where humans have increased their intake of SDA through supplementation, incorporation of SDA itself into blood lipids and cells has been very small but significant increases in EPA have been reported [97-99]. For example, Harris et al. demonstrated that SDA modifies the $\omega-3$ index (EPA+DHA in RBCs) with greater efficiency than ALA [103]. This effect is likely due to increased EPA rather than DHA, since other studies show no net appearance of DHA when SDA is consumed [97, 103-107]. Other studies comparing the effects of SDA, ALA or EPA supplementation on the increase in blood and blood cell VLC $\omega-3$ PUFAs report that EPA supplementation resulted in higher EPA levels than SDA supplementation, which in turn was higher than ALA supplementation. However, neither ALA, nor SDA, nor EPA resulted in higher DHA levels [97-100].

\subsubsection{Stable isotope studies}

Several studies using ALA labelled with either ${ }^{13} \mathrm{C}$ or ${ }^{2} \mathrm{H}$ provide estimates for conversion rates to longer chain more unsaturated derivatives in humans [30, 31, 57, 108-112] (Table 5). Although the limitations of such studies have been discussed by Emken et al. and by Burdge et al. who suggest there are unresolved issues regarding tracer studies including; standardisation, quantification, and which lipid pool should be used as a measurement of fatty acid metabolism [113, 114]. However, there are currently few feasible alternatives to stable-isotope tracer techniques in studying the metabolism of fatty acids in vivo. These tracer studies generally conclude that the conversion of ALA to the longer-chain metabolites EPA and DPA occurs, but is limited, and is greater than conversion to DHA (Table 5). For example, based upon appearance of label in total plasma lipids Emken et al. reported the highest estimated fractional conversion of ALA to DHA of 4\% [49], though most other studies have concluded much lower conversions than this (e.g. $0.05 \%$ or even less) $[57,58$, 108-112, 115, 116] (see Table 5 for details including the lipid pools examined). Burdge et al. detected no significant incorporation of stable-isotope into DHA above background ${ }^{13} \mathrm{C}$ enrichment in men aged 27 to 40 years [30]. Vermunt et al. also described that increasing intake of ALA by a mixed group of healthy men and women actually decreased the synthesis of EPA, DPA and DHA [57], though this observation is in contrast to other studies [56].

Efficiency of conversion of individual steps within the metabolic pathway has been estimated from kinetic analysis based on concentrations of ${ }^{2} \mathrm{H}$ labelled fatty acids in plasma [110]. Overall conclusions from the study were in agreement with others and showed $0.2 \%$ conversion of ALA to EPA, $0.13 \%$ to DPA and $0.05 \%$ to DHA.

Burdge et al. have also identified significant differences in conversion of ALA between women and men, with women having a significantly greater capacity than men to synthesise 
EPA and DHA from ALA. The estimated mean net conversion rate of ALA to EPA in women (mean age 28 years) was $21 \%$ compared to $8 \%$ in men (age range 27 to 40 years) and the estimated mean net conversion rate of ALA to DHA was $9 \%$ in the women and $0 \%$ in the men [30, 31]. Pawlosky et al. reported a decrease in the conversion of DPA to DHA in women, but not men, after consuming a fish based diet providing EPA+DHA [115]. Modification of the diet by increasing consumption of EPA in combination with DHA, or of DHA alone, may affect the extent of ALA conversion, as there is potential for feedback inhibition of the pathway. A small number of studies have examined the impact of modifying the diet on the extent of ALA conversion to EPA and DHA. Emken et al. investigated the effect of increased consumption of DHA. Subjects consumed either $<0.1$ $\mathrm{g} / \mathrm{d}$ DHA or supplemented their diet with $6.5 \mathrm{~g} / \mathrm{d}$ of purified DHA for 90 days [108]. The group receiving supplemental DHA showed 76\% lower EPA synthesis from ALA and $88 \%$ lower DHA synthesis. Burdge et al. compared conversion of ALA within individuals after consumption of $1.6 \mathrm{~g} / \mathrm{d}$ EPA plus DHA over an 8 week period and showed that synthesis of EPA and DPA was decreased, but synthesis of DHA was unaffected [56]. These studies indicate that an increase in intake of VLC $\omega$-3 PUFAs downregulates their synthesis from ALA [42]. Tang et al. suggest this is due to activation of the peroxisome proliferator-activated receptor-alpha leading to inhibition of D6D transcription [117]. Differences between findings of the two studies may be due to the much lower intake of DHA in the Burdge et al. study, which may have been insufficient to inhibit the DPA to DHA conversion. Another study reported that chronic consumption of $L A$ at $17 \mathrm{~g} / \mathrm{d}$ inhibited the conversion of ALA and that, conversely chronic consumption of ALA at $17 \mathrm{~g} / \mathrm{d}$ inhibited the conversion of the LA [111].

In a recent study, Lin et al. analysed measurements of fractional percentages of plasma ${ }^{2} \mathrm{H}_{5}$ ALA and ${ }^{13}$ C-EPA directed toward the synthesis of labelled DHA in 11 newborn infants by using compartmental modelling procedures [118]. Approximately $0.04 \%$ of labelled ALA was converted to plasma EPA, which was efficiently converted to DPA and on to DHA.

Comparison of findings using ${ }^{2} \mathrm{H}_{5}$-ALA and ${ }^{13} \mathrm{C}$-EPA suggested different metabolic handling of endogenous EPA compared to exogenous EPA. However, preformed EPA was still 3.6 times more effective in terms of DHA synthesis than ALA [118].

\subsubsection{Studies investigating longer term changes in intake of alpha-linolenic acid and stearidonic acid}

Concentrations of $\omega-3$ PUFAs within plasma or blood cell pools have been measured after long term (weeks to months) changes (usually increases) in intakes of ALA or SDA in humans. Although there are numerous studies reporting the results of increased ALA intake in humans [32, 97, 106, 119-164] (see Tables 6 and 7), fewer studies have investigated the effects of increased SDA intake [38, 97-100, 104-107, 165-167] (see Table 8).

\subsubsection{Increased intake of alpha-linolenic acid}


A number of studies have reported the effects of consuming increased amounts of ALA for a period of weeks to months on fatty acid composition within plasma or blood cell lipids (Tables 6 and 7). Such dietary modification has usually been achieved via use of encapsulated oils or of foods fortified with ALA-rich oils. Most often the oil used has been flaxseed. The durations of these studies varied between 2 and 160 weeks and doses of ALA ranged from $<1$ to about $20 \mathrm{~g} /$ day (Tables 6 and 7). These studies describe the effects of the dietary intervention on plasma or serum total fatty acids, individual plasma or serum lipid classes, primarily phospholipids, and on platelets, RBCs and leukocytes, primarily peripheral blood mononuclear cells (see Tables 6 and 7). Only one study investigated the effect of decreasing consumption of ALA [168].

Almost all (47 out of 54) studies which increased ALA consumption report increased content of EPA and, where measured, DPA, in blood lipids and blood cells, while most report either little or no change or even a decrease in DHA content (Tables 6 and 7). As an example of data obtained from one of these studies [97], Figure 3 shows the effect of ALA $(0.75 \mathrm{~g} /$ day for 3 weeks and then $1.5 \mathrm{~g}$ /day for 3 weeks) on EPA, DPA and DHA content of plasma phospholipid and RBCs. It is evident that EPA and DPA show small increases, with the increase in EPA being greater ( $23 \%$ and $15 \%$ increases from starting value for EPA in plasma phospholipid and RBCs, respectively and $\sim 5 \%$ and $4 \%$ increases from starting value for DPA in plasma phospholipid and RBCs, respectively), while DHA shows a decrease ( $7 \%$ decrease from starting value for DHA in both plasma phospholipid and RBCs).

Plasma phospholipids may be a mechanism to transport PUFAs to cells and tissues, and their fatty acid composition reflects that of the membranes of some cells [154]. The effect of increased ALA intake on fatty acids in plasma phospholipids has been reported in several studies. Therefore, we chose to evaluate the relationship between increased ALA intake $(\mathrm{g} / \mathrm{d})$ and change in the EPA, DPA and DHA content of this fraction (Figure 4). Combining data from all studies $(n=9)$ examining increased ALA intakes ranging from 2 to $15 \mathrm{~g} / \mathrm{d}$ revealed a positive linear relationship $(p=0.0002)$ between ALA consumption and change in plasma phospholipid EPA content (Figure 4A). The data suggest that each $1 \mathrm{~g}$ increase in ALA intake results in about a $10 \%$ relative increase in EPA content. Five studies investigating increased ALA intakes ranging from $\sim 2$ to $10 \mathrm{~g} / \mathrm{d}$ revealed a dose-dependent relationship ( $\mathrm{p}$ $=0.0011$ ) between ALA consumption and change in plasma phospholipid DPA content (Figure 4B). The data suggest that each $1 \mathrm{~g}$ increase in ALA intake results in about a 4\% relative increase in DPA content. However, combined data from nine studies indicates no change $(p=0.49)$ in plasma phospholipid DHA after increased consumption of ALA (Figure $4 C$ ). The relationship between increased ALA intake and cell phospholipid EPA is also likely to be linear but there are insufficient data for any single cell type on which to base any firm conclusions on this. 
Metabolic competition exists between LA and ALA, and therefore levels of LA within the diet could influence the conversion of ALA to VLC $\omega$-3 PUFAs. Chan et al. demonstrated this by changing dietary LA intakes in normolipidaemic men to either $21 \mathrm{~g}$ or $50 \mathrm{~g} / \mathrm{d}$ for 18 days, whilst providing a constant ALA intake of $7 \mathrm{~g} / \mathrm{d}$. It is important to note that in this study intakes of both LA and ALA were far above those normally consumed in the human diet. EPA content of plasma phosphatidylcholine and phosphatidylethanolamine, and of platelet phosphatidylcholine increased to a greater extent in subjects consuming the lower amount of LA compared to the higher amount [169]. This finding supports the idea that LA decreases ALA conversion to EPA in humans. This interaction between LA and ALA was further explored by Goyens et al. [32]. They described incorporation of EPA into plasma phospholipids being greater in a low LA group ( $3 \%$ of energy from $L A, 0.4 \%$ energy from $A L A$, 7:1 ratio of LA to ALA) than in a high ALA group (7\% of energy from LA, $1.1 \%$ energy from ALA, 7:1 ratio of LA to ALA). The authors argued that exchanging dietary LA for ALA may be the optimal dietary approach to increase VLC $\omega$-3 PUFA status [32]. Although these studies demonstrate that a high LA intake seems likely to inhibit conversion of ALA to EPA, there is little information on the extent to which variations in habitual LA intake affect conversion of ALA consumed at habitual intakes.

Although the focus of most studies has been on the effect of increased ALA intake, because of the interest in strategies to increase EPA and DHA status, Han et al. describe effects of decreasing ALA consumption via use of a low ALA-soybean oil [168]. In this study the low ALA diet provided $54 \%$ of the amount of ALA ( $0.68 \%$ energy) found in the reference soybean oil based diet (1.26\% energy). The findings showed that lower ALA intake resulted in lower plasma EPA (-25\%) and DHA (-5\%) concentrations. This finding supports a close relationship between ALA intake and EPA content of plasma phospholipid (and probably other lipid pools too), such that increasing ALA intake increases EPA, while decreasing ALA intake decreases EPA content. However, as indicated above, the amount of LA and the LA to ALA ratio will also play a role in determining the precise extent of conversion.

Taken together, these studies show that the amount of ALA consumed in the diet is directly related to the amounts of EPA and DPA in blood lipids and blood cells. One implication is that increased ALA intake is a potential strategy to increase EPA, and also DPA, status. Furthermore, the effectiveness of this strategy may be enhanced if LA intake is decreased at the same time as ALA intake is increased. In contrast, these studies also demonstrate that increased consumption of ALA does not increase the amount of in DHA in blood lipids and cells. This conclusion based on dietary intervention studies lasting weeks to months is consistent with findings, described above, from several short term stable isotope studies. Thus increased intake of ALA, even at high doses, does not appear to be a viable strategy to increase DHA status. 
The studies described in Tables 6 and 7 were conducted in adults. There are now a small number of similar studies conducted in infants and children examining the impact of increased intake of ALA [170-173]. Schwartz et al. demonstrated a small increase in concentrations of EPA, DPA and DHA in plasma after increased ALA consumption via meals containing rapeseed oil in 4-10 month old infants [170]. Gracious et al. reported higher EPA and DPA concentrations, but no change in DHA concentration, in plasma after 16 weeks of stepped dose increases in ALA intake up to $6.6 \mathrm{~g} / \mathrm{d}$ in children and adolescents aged 6-17 years [171]. This study is consistent with the observations in adults that an increase in ALA consumption increases EPA and DPA concentration, but not DHA concentration, in plasma and cell lipids. However, some older studies suggest that conversion of ALA to DHA may be more efficient in infants than seen in studies in adults. Sauerwald et al. fed 3 week old term infants a fixed LA diet, where formulas contained $16 \%$ of fat as LA and increasing amounts of ALA $(0.4 \%, 1 \%$ or $3.2 \%)$. The authors estimated that there was a 2.5 fold greater rate of incorporation of DHA into the plasma phospholipid fraction with the highest amount of ALA given [172]. The ability of infants to synthesise DHA from ALA was also reported in two other studies that used ALA addition to formula that did not contain LC-PUFAs. Clark et al. observed increases in plasma total DHA when ALA was increased in formula [173]. Jensen et al. also reported increases in levels of DHA in both plasma and RBCs after increased ALA: infants were fed from birth to age 120 days with formula providing $16 \%$ of fats as LA and either $0.4,0.95,1.7$ or $3.2 \%$ as ALA [174].

These studies may suggest that infants have a greater capacity to convert ALA to DHA than adults, perhaps due to it being a particularly critical development window ( $\omega-3$ LC PUFAs are required for rapid growth of neural tissues in the perinatal period). Brenna suggests a wide variability among human infants in the development of biosynthetic capability to convert ALA to DHA [175].

\subsubsection{Sex differences in alpha-linolenic acid metabolism}

There are few dietary intervention studies investigating effects of increased ALA consumption in men and women alone, with most reporting outcomes in mixed sex groups. However, studies where comparable consumption of ALA between sexes has been investigated indicate that ALA may have a sex-specific effect on EPA, DPA and DHA status in humans.

As mentioned earlier, Burdge et al. examined conversion of ALA to EPA and DHA in women (mean age 28 years) and men (age range 27 to 40 years) in comparable studies [30, 31]. They showed that conversion of ALA to EPA and DHA in women was markedly greater, by 2.5 fold and $>200$ fold, respectively, than that in men. This is supported by kinetic analysis data, which demonstrates that the rate constant coefficient for the conversion of DPA to DHA is approximately 4-fold greater in women than men [116]. Burdge et al. suggest there may be a sex-related difference in the desaturation-elongation pathway [31]. 
Better conversion of ALA in women would suggest that higher concentrations of EPA, DPA and DHA would be seen in blood, cells and tissues in women compared with men. Lohner et al. evaluated by meta-analysis publications from 1975 to 2011 that compared LC PUFA concentrations between men and women [176]. Their analysis showed significantly lower DHA in total plasma lipids (33 studies) and in plasma phospholipids (23 studies) in men than in women. Primary analysis of the phospholipid fraction showed a mean difference in DHA of $0.37 \%$. There was no sex difference in the concentrations of LA or ALA.

In an RCT where men and women where fed an ALA-rich diet (9.5 g/d ALA) for 6 months there were significant differences between sexes in the response to increased dietary ALA [177]. There was a greater increase in the EPA content of plasma phospholipids in women (absolute increase of $2 \%$ ) compared to men (absolute increase of $0.7 \%$ ). However, there was no sex specific enhancement of DPA or DHA content of plasma phospholipids after increased consumption of ALA. Childs et al. also report an inverse relationship between the age of the female participants and the change in EPA content after increased consumption of ALA, which may suggest a role for female sex hormones in regulating the endogenous synthesis of VLC $\omega-3$ PUFAs. Indeed several studies support the idea that sex hormones may regulate the desaturation-elongation pathway, and so affect the metabolism of ALA differently in men and women. For example, Burdge et al. demonstrated that DHA synthesis was 3-fold greater in young adult women using an oral contraceptive pill containing 17alpha-ethylnyloestradiol compared to those who did not [31]. They suggest that the action of oestrogen may therefore explain greater synthesis of EPA and DHA from ALA in young women due to increased activity of the pathway. Ottosson et al. reported that oestrogenbased hormone replacement therapy in postmenopausal women resulted in greater plasma di-homo- $\gamma$-linolenic and arachidonic acid (AA) concentrations than before treatment [178]. Giltay et al. describe greater DHA concentrations in the plasma cholesteryl ester fraction of women $(0.53 \%$ of total fatty acids) compared with men $(0.48 \%$ of total fatty acids) after consumption of increased ALA [179]. Furthermore, it has been shown that male to female transsexuals who were administered 17-alpha-ethylnyloestradiol had increased concentrations of DHA in plasma cholesteryl esters (42\%) [31], whereas testosterone decreased the DHA concentrations by $22 \%$ in female to male transsexuals [179].

\subsubsection{Increased intake of stearidonic acid}

Studies which directly compared the effects of SDA with ALA or EPA supplementation on the concentrations of in EPA, DPA and DHA in humans reported that SDA resulted in higher plasma and cell EPA than ALA [97-100] (Table 8). None of these studies reported an increase in DHA concentrations after an increase in SDA intake, which is consistent with findings following increased intakes of ALA. 
Although there are fewer studies describing effects of increased intake of SDA than of ALA, most conclude that chronically increased consumption of SDA increases plasma and cell concentrations of EPA and DPA, but decreases concentrations of DHA, with few exceptions (Table 8). It seems likely that the relationship between increased SDA intake and increased concentration of EPA and DPA in plasma lipids and blood cells will be linear, as is the case for ALA (Figure 3), but there are too few studies exploring this to be certain.

James et al. compared the metabolism of SDA and ALA: they describe the effect of increased intake of ALA or SDA or EPA for periods of 3 weeks at doses of $0.75 \mathrm{~g} / \mathrm{d}$ and then $1.5 \mathrm{~g} / \mathrm{d}$ [97]. The data obtained clearly demonstrate the superiority of SDA over ALA to increase EPA (and DPA) in plasma phospholipids and RBCs (Figure 5), but there was no increase in DHA with either ALA or SDA (Figure 5).

\subsection{Alpha-linolenic acid and stearidonic acid - human health-related outcomes}

Epidemiological studies in Europe, the USA and Japan indicate decreased risk of CVD [2, 4, 6, 180,181 ] and inflammation [182-185] with increasing consumption of VLC $\omega-3$ PUFAs. VLC $\omega$-3 PUFA supplementation studies have demonstrated beneficial changes in a number of cardiovascular risk factors including fasting TAG concentrations [186, 187], postprandial lipaemia [188], blood pressure [189], platelet aggregation [131, 190, 191], blood coagulation and fibrinolysis [192], heart rate variability [193, 194], cardiac arrhythmias [195], vascular reactivity [196-199] and inflammation [200-204]. However, some reports suggest that these fatty acids increase the susceptibility of LDL to oxidation ex vivo [124, 205, 206], which, if it occurred in vivo, could have a damaging pro-atherogenic effect. VLC $\omega-3$ PUFAs may also modulate immune function $[200,201,204]$. It is possible that ALA and SDA can exert beneficial effects on human health as they act as the precursors to EPA and, to a more limited extent, DHA. ALA also competes with LA for metabolism and so may reduce the ARA content of cells and tissues, which might be important for controlling thrombosis, inflammation, bone loss, immunosuppression and cancer.

\subsubsection{Alpha-linolenic acid and cardiovascular disease}

\subsubsection{Epidemiological associations}

Reported effects of ALA-enriched diets on prevention of CVD are inconsistent. A population based case-control study in Costa Rica reported that a high ALA intake from the diet and a high ALA content in adipose tissue were associated with a lower risk of myocardial infarction (MI) $[207,208]$. Risk of MI decreased by $57 \%$ with median ALA intake of $1.79 \mathrm{~g} / \mathrm{d}(0.65 \%$ energy) compared with $1.11 \mathrm{~g} / \mathrm{d}(0.42 \%$ energy), but it did not decrease further with ALA intakes $>1.79 \mathrm{~g} / \mathrm{d}$. Fish and EPA and DHA intakes, which were low, did not modify the observed association, suggesting that ALA confers cardiovascular protection in populations where intake of VLC $\omega$-3 PUFAs is low [208]. 
The Multiple Risk Factor Intervention Trial showed that dietary ALA intake was significantly inversely associated with mortality from coronary heart disease (CHD) [209]. An ALA intake of $1.36 \mathrm{~g} / \mathrm{d}$ (highest quintile of ALA intake) was associated with $45 \%$ fewer coronary deaths in women compared with an intake of $0.71 \mathrm{~g} / \mathrm{d}$ (lowest quintile of ALA intake) [210]. Asherio et al. also reported that dietary ALA intake was inversely associated with risk of $\mathrm{MI}$ among men [211]. In another study of 4406 men and women, $1.1 \mathrm{~g} / \mathrm{d}$ ALA was associated with $40 \%$ lower mortality from coronary artery disease compared with an intake of $0.5 \mathrm{~g} / \mathrm{d}$ [212]. One prospective cohort study also concluded that a diet rich in ALA is beneficial in CVD [210] . In a meta-analysis of five prospective cohort studies, Brouwer et al. reported that a high intake of ALA was associated with a $20 \%$ decrease in CHD risk compared with a low intake [213]. This conclusion is further supported by a recent meta-analysis which showed that higher ALA intake was associated with a lower risk of CVD: the authors suggest that each increment of $1 \mathrm{~g} / \mathrm{d}$ ALA intake is associated with 10\% lower risk of CHD [214]. However, there is contradictory evidence from another meta-analysis, which identified only a very small, if any, cardioprotective benefit from higher ALA intake [215]. In older epidemiological studies, Oomen et al. and Simon et al. found no association between ALA intake and CHD risk [216, 217]. More recently, Vedtofte et al. suggested that there is no association between ALA intake and risk of ischemic heart disease [218] and Lemtaire et al. concluded that ALA is not associated with incident congestive heart failure (CHF) in older adults [219], which is in agreement with findings from another prospective study by Gode et al. reporting no association between ALA intake and incident CHD [220].

Thus, data are inconsistent, and it is not clear whether ALA intake is associated with reduced incidence of CVD or not. It is possible that dietary intakes of ALA are easily miscalculated because of the self-report questionnaires used to assess fatty acid consumption, and this might contribute to inconsistencies in the literature. Harris et al. used fatty acid biomarkers instead of dietary recalls in a meta-analysis of studies and reported that ALA was inversely associated with non-fatal CHD events [221].

\subsubsection{Intervention studies}

The Lyon Heart Study reported a substantial reduction in coronary events and deaths among MI survivors following a Mediterranean diet which provided $1.5 \mathrm{~g} / \mathrm{d}$ of ALA via an ALA-rich margarine as part of the intervention [222]. At the 27 month follow-up, the risk of cardiac death and non-fatal $\mathrm{MI}$ was lower (by $>60 \%$ ) in the intervention group compared with the control group. After 46 months, subjects adhering to the Mediterranean diet had $50-70 \%$ lower risk of recurrent heart disease [223]. ALA was the only fatty acid significantly associated with a lower risk of the composite primary end point of MI plus cardiovascular death. Fleming et al. suggest that ALA is responsible for the observed effects since EPA and DHA were not associated with lower risk of CHD [224]. However, it is difficult to attribute the findings of this study specifically to increased intake of ALA since other dietary changes were involved. 
The Alpha Omega Trial was a double-blind, placebo-controlled trial in post MI patients [225]. Subjects consumed margarines with different amounts of ALA, EPA+DHA or the combination of ALA+EPA+DHA. Both groups consuming ALA had a daily intake of $2 \mathrm{~g}$, which is not much greater than the amount consumed in many habitual diets (Table 1). There was a nonsignificant $9 \%$ reduction in the primary end point (any major cardiovascular event) with ALA supplementation compared to supplementation with EPA+DHA. There were no differences in cardiovascular events between the groups which received ALA and the groups which did not. However, there was a $27 \%$ reduction in major cardiovascular events among women in the ALA group. This may relate to better conversion of ALA to cardioprotective EPA in women than in men.

\subsubsection{Alpha-linolenic and stearidonic acids and cardiovascular risk factors}

\subsubsection{Blood lipids}

Increased intake of LA has been shown to lower blood total and LDL-cholesterol concentrations, particularly when LA is increased at the expense of SFAs [226]. Studies which investigated the effect of increased ALA consumption on blood cholesterol, TAG, LDLcholesterol and HDL-cholesterol concentrations have shown inconsistent findings [32, 106, $107,119-121,123,128-130,134,136,137,139,140,143-146,158,160,163,164,227-244]$ (Table 9). Several studies have reported that ALA has an LDL-cholesterol lowering effect $[106,107,120,121,134,145,163,164,227,235-237,243-245]$ (Table 9). Although Mantzioris et al. and Pang et al. both suggest that ALA is not as effective as LA at lowering LDL-cholesterol [130, 232], several studies report that the effects of ALA are similar to those of $L A$. The reasons for these differing findings may relate to the nature of the fatty acid replaced by ALA: replacement of SFAs with ALA would lower LDL-cholesterol while replacement of LA with ALA may have no effect. Reports of the effect of ALA on HDLcholesterol are also inconsistent with some studies reporting increases $[119,130,244]$ and others decreases [107, 134, 137, 160, 231, 235, 237, 239, 240] (Table 9). Again, this may relate to the exact nature of the ALA intervention and what fatty acid ALA is replacing. When comparing ALA and LA intake, Bemelmans et al. reported that HDL-cholesterol concentrations were lower after increased ALA intake than after increased LA intake [119].

Some studies have investigated the independent effects of ALA and EPA+DHA on LDLcholesterol concentration, although interpreting the results of such comparisons is made difficult by the fact that ALA can be converted to EPA, and in some sub-groups to DHA, in vivo. Goyens et al. [245] and Finnegan et al. [124] observed more favourable effects of ALA than EPA+DHA on LDL-cholesterol concentration. Both of these studies reported an increase in LDL-cholesterol in subjects consuming an EPA+DHA rich diet compared to those consuming an ALA rich diet. Thus, the effects of ALA and EPA+DHA on LDL-cholesterol are not comparable, and those of ALA are more favourable. 
The reported effects of ALA on fasting TAG concentrations are also inconsistent; although a number of studies report a decrease $[107,134,140,144,146,160,233,243,244]$, the majority (31 out of 40 ) report no effect (Table 9). There is consistent evidence that EPA and DHA lower blood TAG concentrations [186, 246, 247]. Egert et al. evaluated the effects of increased dietary intake of ALA, EPA and DHA on serum TAG in normolipidemic non-obese subjects [140]. The subjects consumed margarines providing either $4.4 \mathrm{~g}$ of ALA, or $2.2 \mathrm{~g}$ of EPA or $2.3 \mathrm{~g}$ of DHA ethyl ester daily for 6 weeks. The study confirmed the TAG lowering effect of EPA ( $15 \%$ lower) and DHA (30\% lower) and reported a $15 \%$ reduction in fasting serum TAG in the ALA group [140]. Patenaude et al. compared the effect of increased consumption of ALA, from flaxseed oil ( $6 \mathrm{~g} / \mathrm{d}$ for 4 weeks), in two age groups and reported a $20 \%$ decrease in circulating TAG concentration in younger subjects (18-29 y) compared to a $3.5 \%$ increase in older subjects (45-69 y) [144]. Some studies which directly compare the effects of ALA and LA on fasting TAG concentrations suggest that the effects of ALA are not markedly different from those of LA [134, 229, 231, 232, 240], while others describe higher TAG concentrations after increased ALA intake but not after a high-LA diet [124, 227]. For example, Bemelmans et al. reported $12 \%$ higher plasma TAG concentrations after ALA than after LA [119]. Thus, whether ALA is seen to lower blood TAG concentrations may depend upon what ALA is replacing in the diet and the exact fatty acid comparisons being made.

Three studies investigated the effects of SDA-rich soybean oil on blood lipid concentrations in humans. Krul et al. report no effect of consuming different amounts of SDA $(0.43,1.3,2.6$ or $5.2 \mathrm{~g} / \mathrm{d}$ ) from this oil for 12 weeks on plasma cholesterol or TAG concentrations in healthy male and female subjects [100]. Harris et al. also found no change in serum cholesterol or TAG concentrations after consuming of $3.7 \mathrm{~g} / \mathrm{d}$ SDA from SDA-rich soybean oil for 16 weeks in overweight or obese adults [166]. Another study reported no change in serum cholesterol concentration after consuming $4.2 \mathrm{~g} / \mathrm{d}$ SDA for 12 weeks, although there was a nonsignificant trend ( $9 \%$ decrease) towards lower TAG concentration [98]. Furthermore, consuming $10 \mathrm{~g}$ Echium oil/d (providing $1.2 \mathrm{~g} \mathrm{SDA} / \mathrm{d}$ ) did not alter serum total cholesterol, LDL-cholesterol, HDL-cholesterol or TAG concentrations in overweight and obese subjects [105]. It is possible that some of these studies were too small to detect a significant effect of SDA on blood lipids.

\subsubsection{Postprandial lipaemia}

Lichenstien et al. reported no differences in the postprandial TAG response to a test meal in subjects who consumed diets rich in rapeseed, corn or olive oil and so differing in ALA content [248]. Finnegan et al. reported no effect of modified margarines providing 4.5 or 9 $\mathrm{g} / \mathrm{d}$ of ALA for 6 months on the postprandial TAG response to a test meal, compared to starting response or to use of an LA-rich margarine [124].

One study which investigated the effect of SDA (4.2 g/day) on postprandial TAG in hypertriglyceridemic subjects reported no effect after 12 weeks intervention [98]. 
Overall, it appears that neither ALA nor SDA affect the post-prandial TAG response compared with other plant-derived unsaturated fatty acids.

\subsubsection{Low-density lipoprotein oxidation}

Compared to a monounsaturated fat-rich diet, consuming $20 \mathrm{~g} / \mathrm{d}$ ALA for 4 weeks decreased the lag time for ex vivo Cu-induced oxidation of LDL by $14 \mathrm{~min}$ in overweight male and female subjects [231]. Additionally, the content of thiobarbituric acid reactive substances, which are the end product of PUFA oxidation, in the oxidised LDL was higher if the LDL came from the subjects on the ALA rich diet. These observations indicate increased susceptibility to oxidation of LDL which is related to increased cardiovascular risk and it may reflect a higher PUFA content of LDL. However, a more recent study reported no effect of consuming margarines providing 4.5 or $9 \mathrm{~g} / \mathrm{d}$ ALA on lag time of LDL oxidation, compared with consuming an LA-rich margarine [124]. In addition, Ezakji et al. found that a diet which provided $4.2 \mathrm{~g} / \mathrm{d}$ ALA did not alter plasma lipid peroxide or oxidised LDL concentrations in older Japanese adults [89]. Another trial saw no effect on serum oxidised LDL concentrations after 10 weeks intervention with $4 \mathrm{~g} / \mathrm{d}$ ALA from flaxseed [103]. The difference in findings of the latter three studies compared with the study of Sodergren et al. [237] may relate to the lower ALA intake used in the latter studies. Kaul et al. did not detect a change in lag time of LDL oxidation after consumption of fish oil (352 mg/d EPA and 242 $\mathrm{mg} / \mathrm{d}$ DHA), flaxseed oil (1 g/d ALA) or hempseed oil (400 mg/d ALA) for 12 weeks [143], perhaps reflecting the low intakes of PUFAs used. Overall, these studies suggest that ALA intakes up to 6 times greater than that found in the typical UK diet ( 1.5/d) do not significantly alter markers of blood lipid peroxidation when consumed for relatively short periods of time. However, substantially higher intakes (for example 13-fold greater than the typical UK intake) may increase LDL oxidation, although the health implications of this are limited as such high intakes are unlikely to be achieved in most populations.

\subsubsection{Blood pressure}

It was reported that a $1 \%$ increase in adipose tissue ALA content (a marker of dietary ALA intake) was associated with a $5 \mathrm{mmHg}$ decrease in systolic and diastolic blood pressures [249], and in a large prospective study an inverse association between dietary ALA intake and blood pressure was observed [250]. Caligiuri et al. reported that participants with peripheral arterial disease, $75 \%$ of whom were hypertensive, who consumed $30 \mathrm{~g}$ milled flaxseed/d (providing $7 \mathrm{~g} \mathrm{ALA} / \mathrm{d}$ ) for 6 months exhibited significant reductions in systolic (-10 $\mathrm{mm} \mathrm{Hg}$ ) and diastolic $(-7 \mathrm{mmHg})$ blood pressure [251]. However, other studies have not detected an effect of ALA intake or status on blood pressure. Increasing ALA consumption from habitual intake to $38 \mathrm{~g} / \mathrm{d}$ for 2 weeks did not significantly alter systolic or diastolic blood pressure in either normotensive or hypotensive subjects [233]. Similarly, consuming $9.2 \mathrm{~g} / \mathrm{d}$ ALA for 6 weeks did not significantly alter systolic or diastolic blood pressure in normotensive, hypercholesterolaemic subjects [229]. In addition, Finnegan et al. showed 
that increasing ALA intake from $1.5 \mathrm{~g} / \mathrm{d}$ to 4.5 or $9 \mathrm{~g} / \mathrm{d}$ for 6 months did not change blood pressure significantly in either group [124]. Similarly, Bemelmans et al. found that consuming $6.3 \mathrm{~g} / \mathrm{d}$ ALA for 2 years did not significantly alter systolic or diastolic blood pressure in subjects with multiple cardiovascular risk factors [119]. Together, these studies show that high or prolonged increase in ALA intake has little effect on blood pressure. This is in contrast to the frequently reported hypotensive effect of EPA+DHA, confirmed in several meta-analyses, although most studies report that high dose EPA and DHA is needed to lower blood pressure [252-254].

\subsubsection{Vascular reactivity}

Consuming $20 \mathrm{~g} / \mathrm{d}$ ALA for 4 weeks in exchange for oleic acid increased arterial compliance (aortic flow velocity and aortic root driving pressure) in obese subjects [231]. Further studies investigating whether ALA or SDA affect vascular reactivity are required.

\subsubsection{Platelet aggregation and haemostasis}

Increasing intake of ALA results in decreased levels of AA in platelets and increased levels of EPA [129, 131, 150, 155, 156, 158, 159] (Table 7). This may result in modulation of platelet aggregation, as this is partly regulated by AA and EPA-derived eicosanoids $[255,256]$. Consuming $18 \mathrm{~g} / \mathrm{d}$ ALA for 23 days decreased collagen-induced platelet aggregation in healthy men compared to those consuming an LA-rich diet [150]. Another study reported decreased ADP-induced platelet aggregation in hyperlipidaemic participants who consumed an ALA-rich (2.1\% energy as ALA) compared to a low-ALA diet (0.3\% energy from ALA) [126]. However, some studies in which ALA intake was increased did not find a significant effect on collagen-induced platelet aggregation [129, 228]. Kaul et al. also reported that flaxseed oil supplementation (providing $1 \mathrm{~g} / \mathrm{d}$ ALA) induced no significant change in collagen or thrombin stimulated platelet aggregation [143], although this is a much lower dose of ALA than used in other studies looking at these outcomes. Overall, it is not clear whether high ALA intakes reduce platelet aggregation or not, due to the inconsistencies in findings from different studies. These inconsistencies seem not to be related to dose of ALA used.

Table 10 summarises the findings of intervention studies where haemostatic factors have been investigated after increased consumption of ALA [119, 123, 128, 129, 139, 151, 228, $234,235,257$ ]. Most studies (9 out of 10 ) reported no significant effect of increasing ALA intake on haemostatic factors (e.g., fibrinogen concentration, prothrombin time, PAl-1 activity or factor VII activity), even when high intakes (up to $20 \mathrm{~g} /$ day) [128, 129, 139, 234, 235] and long durations (up to 48 weeks) $[123,139,234]$ were used (Table 10). Overall, these finding show that increasing ALA intake, even quite markedly, does not alter haemostasis significantly.

\subsubsection{Alpha-linolenic acid, stearidonic acid and inflammation}


Oxylipins produced from $\omega-6$ and $\omega-3$ PUFAs including octadecanoids, eicosanoids, and docosanoids are intimately involved in inflammatory processes [258] and therefore play an essential role in both the progress and intensity of a range of chronic diseases, although many derived from the VLC $\omega-3$ PUFAs EPA, DPA and DHA, including resolvins and protectins, have been shown to resolve inflammatory processes [258], and so are considered to be protective. Increased consumption of ALA or SDA has been shown to increase the proportion of EPA and DPA in membranes of inflammatory cells such as neutrophils, monocytes and lymphocytes [38, 99, 107, 128, 130, 133, 152-154, 163] (Tables 7 and 8 ), indicating the potential of plant derived $\omega-3$ PUFAs to reduce inflammation and to protect against chronic inflammatory diseases.

Several plasma inflammatory markers are associated with increased risk of atherosclerosis including C-reactive protein (CRP), soluble intercellular cell adhesion molecule-1 (sICAM-1), and soluble vascular cell-adhesion molecule-1 (sVCAM-1) [259]. In the Nurses' Health Study 1 cohort there was a significant negative association between dietary ALA intake and plasma CRP, interleukin-6 (IL-6) and soluble E-selectin concentrations, after adjustment for body mass index, physical activity, smoking status and intakes of LA and SFAs [260]. This observation supports the idea that ALA may decrease inflammation.

Intervention studies that have investigated the effect of increased ALA on inflammatory responses in humans have measured either concentrations of inflammatory markers in blood or inflammatory cell responses ex vivo [97, 132, 134, 139, 143, 146, 152-154, 161, $163,235,240,244,257,261-263$ ] (Table 11). Caughey et al. reported 30\% less TNF- $\alpha$ and IL$1 \beta$ production and $20 \%$ less $\mathrm{TXB}_{2}$ and $\mathrm{PGE}_{2}$ production by endotoxin-stimulated mononuclear cell cultures obtained from healthy subjects who consumed approximately 14 $\mathrm{g} / \mathrm{d}$ ALA for 4 weeks compared to baseline and a control group [152]. Ralladis et al. reported lower CRP (38\%), serum amyloid A (SAA) (23\%), and IL-6 (10\%) in dyslipidaemic patients after consuming $7 \mathrm{~g}$ ALA/d for 3 months, compared to subjects who consumed a LA rich diet [240]. Hypercholesterolaemic patients who consumed 6-8 g/d ALA for 2 years had a $12.5 \%$ decrease in blood CRP concentration, although there was no change in sICAM-1, IL-6 or IL-10 concentrations [261]. Egert et al. reported that consuming $0.9 \mathrm{~g} / \mathrm{d}$ or $3.4 \mathrm{~g} / \mathrm{d}$ ALA significantly decreased the serum concentrations of CRP, TNF- $\alpha$, IL-6, sICAM-1 and sEselectin in male and female subjects [257]. High ALA intake led to more a pronounced reduction in the serum concentration of YKL-40 compared to the lower intake of ALA [257]. Two recent studies which investigated the effect of increased ALA intake in patients receiving haemodialysis reported significant decreases in CRP concentrations after 8 weeks consuming $40 \mathrm{~g} / \mathrm{d}$ ground flaxseed [244] or after consuming $30 \mathrm{~g} / \mathrm{d}$ milled sesame, pumpkin and flaxseed mixture for 12 weeks [146]. TNF- $\alpha$ and IL- 6 concentrations were also reduced in the latter study. Thus, 9 out of 19 studies have reported a decrease in inflammatory markers following increased intake of ALA for 4 weeks or more (Table 11). Differences in 
findings among studies may relate to the amount of ALA used, the duration of the study or other aspects of the diet or the subject group being studied.

Caligiuri et al. demonstrated a significant decrease in plasma concentrations of proinflammatory 5-HETE (derived from the $\omega$-6 PUFA AA), 9,10,13-TriHOME and 9,12,13TriHOME (both derived from the $\omega-6$ PUFA LA) in older healthy subjects (aged 45-64 years) after 4 weeks of dietary intervention of one muffin/day containing $30 \mathrm{~g}$ of milled flaxseed ( 6 $\mathrm{g} / \mathrm{d}$ ALA) [264]. However, although there was an increase in plasma ALA in these subjects, they showed no changes in ALA-derived oxylipins, and the authors suggested that high concentrations of ALA may decrease metabolism of long-chain PUFAs to oxylipins [264].

In the first study to examine the effect of SDA on inflammatory markers, James et al. reported that there was no effect on TNF- $\alpha$ or IL-1 $\beta$ production by endotoxin-stimulated mononuclear cells after supplementation with SDA-ethyl ester at $0.75 \mathrm{~g} / \mathrm{d}$ for 3 weeks followed by a further 3 weeks at $1.5 \mathrm{~g} / \mathrm{d}$ [97].

\subsubsection{Alpha-linolenic and stearidonic acids and immune function}

Few studies have investigated the effects of increased intake of ALA on immune functions other than inflammation [132, 154, 262, 265-267] (Table 12). Increasing ALA intake to $20 \mathrm{~g} / \mathrm{d}$ for 8 weeks decreased some, but not all, immune parameters [265]. For example, T cell proliferation was decreased in response to one mitogenic stimulant, but not to others. The observed decreased delayed type hypersensitivity response, which is the summation of the in vivo response to intradermal challenge with seven antigens, was in accordance with the decreased T cell function. However, Kew et al. reported no change from study entry in $T$ cell proliferation or in a range of other neutrophil, monocyte and lymphocyte functions in healthy subjects who consumed either 4.5 or $9 \mathrm{~g} / \mathrm{d}$ ALA for 24 weeks [154]. Other studies involving ALA intakes from 2 to $9 \mathrm{~g} / \mathrm{d}$ also report no change in range of immune functions $[132,262,266,267]$ (Table 12). Thus, although very high intakes of ALA may suppress some aspects of immune function [265], the overall conclusion from studies using ALA intakes of 2 to $9 \mathrm{~g} /$ day for a duration of at least 12 weeks is that ALA at achievable intakes does not influence immune function. Therefore, it is not likely that variations or achievable increases in ALA intake will affect host defences against microorganisms.

Miles et al. examined the effect of consuming 1g/d SDA (from Echium oil) on immune function in overweight and healthy weight subjects [99]. There was no effect of increased SDA intake on any immune parameter measured. Walker et al. suggest the low dose of SDA used in this study may be the reason for the lack of effect on immune function, since the amount of SDA given was too low to significantly enrich the EPA content of the cells involved in the immune response [268].

\section{Summary and conclusions}


ALA is an essential fatty acid. It is the substrate for the synthesis of the bioactive VLC $\omega-3$ PUFAs EPA and DHA that are associated with health benefits in humans. SDA is the product of ALA metabolism and is also a substrate for synthesis of EPA and DHA. The primary source of EPA and DHA is seafood, especially fatty fish, which may not be sustainable. ALA and SDA are synthesised in plants and represent more sustainable sources of $\omega-3$ PUFAs. There are a large number of studies investigating the effect of increasing intake of ALA on fatty acid composition of blood lipids and blood cells and on cardiovascular risk factors. These studies have used a wide range of ALA intakes and been of varying duration. Relatively few studies have investigated the effect of increasing intake of SDA. Most of these studies of ALA and SDA have been conducted in healthy subjects. Studies using stable isotopes to trace ALA metabolism have revealed that $\beta$-oxidation is the main fate of ingested ALA and that a relatively small proportion is metabolised to EPA and an even smaller proportion to DHA. However, there is evidence that ALA conversion to EPA and DHA is greater in young women than in young men, but comparisons between sexes have not been made for other age groups. ALA is stored in adipose tissue and humans have substantial ALA stores (probably around $100 \mathrm{~g}$ in normal weight individuals). Studies where ALA intake has been increased for a period of weeks or months show increased content of EPA, and also DPA, in blood lipids and blood cells, with clear dose-dependent increases being seen where there are sufficient data to explore these. In contrast, there appears to be no increase in the DHA content of blood lipids and blood cells with increased ALA intake. These observations are consistent with those from the stable isotope studies. Increased conversion of ALA to EPA has been reported with lowering of LA intake, as well as with increased ALA intake. EPA and DPA are increased more with SDA than with ALA, when given at the same intake levels, consistent with the position of SDA in the pathway of conversion being closer to EPA. Thus, both ALA and SDA may be useful alternatives to EPA, but they seem unlikely to provide an alternative to $\mathrm{DHA}$, although this has not been fully explored in all subgroups of the population including pregnant and lactating women and infants.

Since EPA and DHA have a range of health benefits, there has been much interest in determining whether their plant-derived precursors share those benefits. ALA has been widely explored with regard to its effect on blood lipids and inflammation and there has been more limited examination of its effect on other risk factors for CVD. The effects reported are rather inconsistent, perhaps reflecting comparisons being made, the dose and duration of the study, and the health status of the subjects investigated. ALA may have a cholesterol and LDL-cholesterol lowering effect that is similar to that of the $\omega-6$ PUFA LA, but effects on HDL-cholesterol and TAG are not clear. There are no reported effects of ALA on haemostatic factors and few reported effects on LDL oxidation, blood pressure, platelet aggregation or immune function. Where effects of high dose ALA on inflammation have been reported, these may relate to its conversion to EPA; this may also be the case where effects of ALA on platelet aggregation are reported. Some epidemiological and case-control studies report a protective effect of ALA on CVD morbidity and mortality; this is supported 
by some long-term intervention studies. This effect may relate to the cholesterol-lowering effect of ALA and/or to effects on other risk factors which might be mediated by EPA rather than ALA itself. Thus, in the absence of significant intake of preformed EPA, there is a role for ALA in human health. Nevertheless, ALA seems unlikely to be an effective substitute for DHA. There are few studies of the effect of SDA on health-related outcomes in humans. However, because SDA is superior to ALA as a substrate for biosynthesis of EPA (and DPA), there is greater potential for health improvement with SDA than with ALA.

This review has identified several research gaps. First, the conversion of ALA to EPA, DPA and DHA should be explored across several sub-groups of the population including children, adolescents, pregnant and lactating women, and the elderly and the influence of sex on this conversion more clearly identified. Secondly, regulation of the pathway of conversion of ALA to VLC $\omega-3$ PUFAs needs to be better elucidated, including identification of the interactions among the enzymes acting at the different sites and of the genes encoding those enzymes and identification of endogenous and exogenous regulatory factors involved. Apart from age and sex, such factors will include the LA and micronutrient contents of the diet, sensitivity to insulin, and genotypic and epigenetic variation. Thirdly, the role of different tissues in synthesis of VLC $\omega-3$ PUFAs from ALA in humans needs to be better described. Fourthly, due to the apparent inconsistency between the capacity for conversion of ALA to VLC $\omega-3$ PUFAs (which is generally considered to be limited) and the reported associations between polymorphisms or epimutations in genes that encode the main enzymes in the PUFA biosynthesis pathway, there is a need for studies that integrate dietary analysis, assessment of ALA conversion, measurement of EPA, DPA and DHA status, and analysis of gene polymorphisms and epigenetic variations in carefully defined human cohorts. Finally, there should be further research on handling and metabolism of SDA in humans, on its biological effects and on its mechanisms of action.

\section{Acknowledgements}

EJB is supported by the Biotechnology and Biological Sciences Research Council under the Food Security Doctoral Training Programme and by a Scholarship from the University of Southampton Faculty of Medicine.

\section{References}

[1]. Calder PC. Very long chain omega-3 (n-3) fatty acids and human health. European Journal of Lipid Science and Technology 2014;116:1280-300.

[2]. Calder PC. n-3 Fatty acids and cardiovascular disease: evidence explained and mechanisms explored. Clin Sci (Lond) 2004;107:1-11.

[3]. Yokoyama M, Origasa H, Matsuzaki M, Matsuzawa Y, Saito Y, Ishikawa Y, et al. Effects of eicosapentaenoic acid on major coronary events in hypercholesterolaemic patients (JELIS): a randomised open-label, blinded endpoint analysis. Lancet 2007;369:1090-8.

[4]. Marik PE, Varon J. Omega-3 dietary supplements and the risk of cardiovascular events: a systematic review. Clin Cardiol 2009;32:365-72. 
[5]. Chowdhury R, Warnakula S, Kunutsor S, Crowe F, Ward HA, Johnson L, et al. Association of dietary, circulating, and supplement fatty acids with coronary risk: a systematic review and meta-analysis. Ann Intern Med 2014;160:398-406.

[6]. Bucher HC, Hengstler P, Schindler C, Meier G. N-3 polyunsaturated fatty acids in coronary heart disease: a meta-analysis of randomized controlled trials. Am J Med 2002;112:298-304.

[7]. Studer M, Briel M, Leimenstoll B, Glass TR, Bucher HC. Effect of different antilipidemic agents and diets on mortality: a systematic review. Arch Intern Med 2005;165:725-30.

[8]. Casula M, Soranna D, Catapano AL, Corrao G. Long-term effect of high dose omega-3 fatty acid supplementation for secondary prevention of cardiovascular outcomes: A meta-analysis of randomized, placebo controlled trials [corrected]. Atheroscler Suppl 2013;14:243-51.

[9]. SanGiovanni JP, Parra-Cabrera S, Colditz GA, Berkey CS, Dwyer JT. Meta-analysis of dietary essential fatty acids and long-chain polyunsaturated fatty acids as they relate to visual resolution acuity in healthy preterm infants. Pediatrics 2000;105:1292-8.

[10]. Calder PC. PUFA, inflammatory processes and rheumatoid arthritis. Proc Nutr Soc 2008;67:40918.

[11]. Barros R, Moreira A, Fonseca J, Delgado L, Castel-Branco MG, Haahtela T, et al. Dietary intake of alpha-linolenic acid and low ratio of n-6:n-3 PUFA are associated with decreased exhaled NO and improved asthma control. Br J Nutr 2011;106:441-50.

[12]. Rizos EC, Ntzani EE, Bika E, Kostapanos MS, Elisaf MS. Association between omega-3 fatty acid supplementation and risk of major cardiovascular disease events: a systematic review and meta-analysis. JAMA 2012;308:1024-33.

[13]. Kwak SM, Myung SK, Lee YJ, Seo HG, Korean Meta-analysis Study G. Efficacy of omega-3 fatty acid supplements (eicosapentaenoic acid and docosahexaenoic acid) in the secondary prevention of cardiovascular disease: a meta-analysis of randomized, double-blind, placebocontrolled trials. Arch Intern Med 2012;172:686-94.

[14]. Calder PC, Yaqoob P. Marine omega-3 fatty acids and coronary heart disease. Curr Opin Cardiol 2012;27:412-9.

[15]. Ma DW, Seo J, Switzer KC, Fan YY, McMurray DN, Lupton JR, et al. n-3 PUFA and membrane microdomains: a new frontier in bioactive lipid research. J Nutr Biochem 2004;15:700-6.

[16]. Nakamura MT, Cheon Y, Li Y, Nara TY. Mechanisms of regulation of gene expression by fatty acids. Lipids 2004;39:1077-83.

[17]. Shaikh SR, Edidin M. Polyunsaturated fatty acids, membrane organization, T cells, and antigen presentation. Am J Clin Nutr 2006;84:1277-89.

[18]. Turk HF, Chapkin RS. Membrane lipid raft organization is uniquely modified by n-3 polyunsaturated fatty acids. Prostaglandins Leukot Essent Fatty Acids 2013;88:43-7.

[19]. Weaver KL, Ivester P, Seeds M, Case LD, Arm JP, Chilton FH. Effect of dietary fatty acids on inflammatory gene expression in healthy humans. J Biol Chem 2009;284:15400-7.

[20]. Georgiadi A, Boekschoten MV, Muller M, Kersten S. Detailed transcriptomics analysis of the effect of dietary fatty acids on gene expression in the heart. Physiol Genomics 2012;44:35261.

[21]. World Health Organisation. Population nutrient intake goals for preventing diet-related chronic diseases. http://www.who.int/nutrition/topics/5 population nutrient/en/index13.html (accessed 06/11/2014).

[22]. Marine Conservation Society Feed Event. http://www.mcsuk.org/what we do/Fishing+for+our+future/Aquaculture++what+we+do/Feed+event (accessed 06/11/2014).

[23]. Roberts C. Feeding the world on fish. http://www.fhf.org.uk/meetings/meet 2010/2010-0316 roberts.pdf (accessed 06/11/2014).

[24]. Ministry of Agriculture Fisheries and Food. Dietary Intake of lodine and Fatty Acids. Food Information Surveillance Sheet. London: Ministry of Agriculture, Fisheries and Food 1997;127. 
[25]. Hulshof KF, van Erp-Baart MA, Anttolainen M, Becker W, Church SM, Couet C, et al. Intake of fatty acids in western Europe with emphasis on trans fatty acids: the TRANSFAIR Study. Eur J Clin Nutr 1999;53:143-57.

[26]. Ollis TE, Meyer BJ, Howe PR. Australian food sources and intakes of omega- 6 and omega-3 polyunsaturated fatty acids. Ann Nutr Metab 1999;43:346-55.

[27]. Kris-Etherton PM, Taylor DS, Yu-Poth S, Huth P, Moriarty K, Fishell V, et al. Polyunsaturated fatty acids in the food chain in the United States. Am J Clin Nutr 2000;71:179S-88S.

[28]. Innis SM, Elias SL. Intakes of essential n- 6 and n-3 polyunsaturated fatty acids among pregnant Canadian women. Am J Clin Nutr 2003;77:473-8.

[29]. EFSA Panel on Dietetic Products, Nutrition and Allergies (NDA). Scientific Opinion on Dietary Reference Values for fats, including saturated fatty acids, polyunsaturated fatty acids, monounsaturated fatty acids, trans fatty acids, and cholesterol. EFSA J;8:1461.

[30]. Burdge GC, Jones AE, Wootton SA. Eicosapentaenoic and docosapentaenoic acids are the principal products of alpha-linolenic acid metabolism in young men. Br J Nutr 2002;88:35563.

[31]. Burdge GC, Wootton SA. Conversion of alpha-linolenic acid to eicosapentaenoic, docosapentaenoic and docosahexaenoic acids in young women. Br J Nutr 2002;88:411-20.

[32]. Goyens PL, Spilker ME, Zock PL, Katan MB, Mensink RP. Conversion of alpha-linolenic acid in humans is influenced by the absolute amounts of alpha-linolenic acid and linoleic acid in the diet and not by their ratio. Am J Clin Nutr 2006;84:44-53.

[33]. Vinton NE, Heckenlively JR, Laidlaw SA, Martin DA, Foxman SR, Ament ME, et al. Visual function in patients undergoing long-term total parenteral nutrition. Am J Clin Nutr 1990;52:895-902.

[34]. Sinclair AJ, Attar-Bashi NM, Li D. What is the role of alpha-linolenic acid for mammals? Lipids 2002;37:1113-23.

[35]. Astorg P, Arnault N, Czernichow S, Noisette N, Galan P, Hercberg S. Dietary intakes and food sources of n-6 and n-3 PUFA in French adult men and women. Lipids 2004;39:527-35.

[36]. Jeffrey BG, Weisinger HS, Neuringer M, Mitchell DC. The role of docosahexaenoic acid in retinal function. Lipids 2001;36:859-71.

[37]. Mitchell DC, Niu SL, Litman BJ. Enhancement of G protein-coupled signaling by DHA phospholipids. Lipids 2003;38:437-43.

[38]. Surette ME, Edens M, Chilton FH, Tramposch KM. Dietary echium oil increases plasma and neutrophil long-chain ( $n-3)$ fatty acids and lowers serum triacylglycerols in hypertriglyceridemic humans. J Nutr 2004;134:1406-11.

[39]. Berti M, Johnson BL, Dash S, Fisher S, Wilckens R, Hevia F. Echium: A source of stearidonic acid adapted to the Northern Great Plains in the US. Issues in new crops and new uses 2007.

[40]. Bioriginal. Echium oil. http://www.bioriginal.com/learning-center/omega-ingredients/plantsourced/echium-oil-eu/ (accessed 17/11/2014).

[41]. Ursin VM. Modification of plant lipids for human health: development of functional land-based omega-3 fatty acids. J Nutr 2003;133:4271-4.

[42]. Burdge GC, Calder PC. Dietary alpha-linolenic acid and health-related outcomes: a metabolic perspective. Nutr Res Rev 2006;19:26-52.

[43]. British Nutrition Foundation. N-3 Fatty Acids and Health - Briefing Paper. British Nutrition Foundation, London; 1999.

[44]. Papanikolaou Y, Brooks J, Reider C, Fulgoni VL, 3rd. U.S. adults are not meeting recommended levels for fish and omega-3 fatty acid intake: results of an analysis using observational data from NHANES 2003-2008. Nutr J 2014;13:31.

[45]. Guil-Guerrero JL. Stearidonic acid (18:4n-3): Metabolism, nutritional importance, medical uses and natural sources. Eur J Lipid Sci Technol 2007;109:1226-36.

[46]. Deckelbaum RJ, Torrejon C. The omega-3 fatty acid nutritional landscape: health benefits and sources. J Nutr 2012;142:587S-91S. 
[47]. Harris WS. Stearidonic acid-enhanced soybean oil: a plant-based source of ( $n-3)$ fatty acids for foods. J Nutr 2012;142:600S-04S.

[48]. Bentley S. Corn gromwell: a new oil crop for UK farmers, containing stearidonic acid (SDA), an omage-3 fatty acid from plants with the health benefit of fish oils. http://www.niab.com/pages/id/319/Corn Gromwell. (accessed 04/12/2014).

[49]. Emken EA, Adlof RO, Gulley RM. Dietary linoleic acid influences desaturation and acylation of deuterium-labeled linoleic and linolenic acids in young adult males. Biochim Biophys Acta 1994;1213:277-88.

[50]. Saunders DR, Sillery JK. Absorption of triglyceride by human small intestine: dose-response relationships. Am J Clin Nutr 1988;48:988-91.

[51]. Andersen LF, Solvoll K, Johansson LR, Salminen I, Aro A, Drevon CA. Evaluation of a food frequency questionnaire with weighed records, fatty acids, and alpha-tocopherol in adipose tissue and serum. Am J Epidemiol 1999;150(:75-87.

[52]. Geerling BJ, v Houwelingen AC, Badart-Smook A, Stockbrugger RW, Brummer RJ. Fat intake and fatty acid profile in plasma phospholipids and adipose tissue in patients with Crohn's disease, compared with controls. Am J Gastroenterol 1999;94:410-7.

[53]. Heath RB, Karpe F, Milne RW, Burdge GC, Wootton SA, Frayn KN. Selective partitioning of dietary fatty acids into the VLDL TG pool in the early postprandial period. $J$ Lipid Res 2003;44:2065-72.

[54]. McCloy U, Ryan MA, Pencharz PB, Ross RJ, Cunnane SC. A comparison of the metabolism of eighteen-carbon 13C-unsaturated fatty acids in healthy women. J Lipid Res 2004;45:474-85.

[55]. Nettleton JA. Omega-3 fatty acids: comparison of plant and seafood sources in human nutrition. J Am Diet Assoc 1991;91:331-7.

[56]. Burdge GC, Finnegan YE, Minihane AM, Williams CM, Wootton SA. Effect of altered dietary n-3 fatty acid intake upon plasma lipid fatty acid composition, conversion of [13C]alpha-linolenic acid to longer-chain fatty acids and partitioning towards beta-oxidation in older men. $\mathrm{Br} \mathrm{J}$ Nutr 2003;90:311-21.

[57]. Vermunt SH, Mensink RP, Simonis MM, Hornstra G. Effects of dietary alpha-linolenic acid on the conversion and oxidation of 13C-alpha-linolenic acid. Lipids 2000;35:137-42.

[58]. Burdge GC, Wootton SA. Conversion of $\alpha$-linolenic acid to palmitic, palmitoleic, stearic and oleic acids in men and women. Prostaglandins Leukotr Essent Fatty Acids 2003;69:283-90.

[59]. Nakamura MT, Nara TY. Structure, function, and dietary regulation of delta6, delta5, and delta9 desaturases. Annu Rev Nutr 2004;24:345-76.

[60]. Agbaga MP, Mandal MN, Anderson RE. Retinal very long-chain PUFAs: new insights from studies on ELOVL4 protein. J Lipid Res 2010;51:1624-42.

[61]. Sassa T, Kihara A. Metabolism of very long-chain fatty acids: genes and pathophysiology. Biomol Ther (Seoul) 2014;22:83-92.

[62]. Bernert JT, Jr., Sprecher H. Studies to determine the role rates of chain elongation and desaturation play in regulating the unsaturated fatty acid composition of rat liver lipids. Biochim Biophys Acta 1975;398:354-63.

[63]. Sprecher H, Chen Q, Yin FQ. Regulation of the biosynthesis of 22:5n-6 and 22:6n-3: a complex intracellular process. Lipids 1999;34:S153-6.

[64]. Hrelia S, Celadon M, Rossi CA, Biagi PL, Bordoni A. Delta-6-desaturation of linoleic and alphalinolenic acids in aged rats: a kinetic analysis. Biochem Int 1990;22:659-67.

[65]. Williard DE, Nwankwo JO, Kaduce TL, Harmon SD, Irons M, Moser HW, et al. Identification of a fatty acid delta6-desaturase deficiency in human skin fibroblasts. J Lipid Res 2001;42:501-8.

[66]. D'Andrea S, Guillou H, Jan S, Catheline D, Thibault JN, Bouriel M, et al. The same rat Delta6desaturase not only acts on 18- but also on 24-carbon fatty acids in very-long-chain polyunsaturated fatty acid biosynthesis. Biochem J 2002;364:49-55.

[67]. Sprecher H. Metabolism of highly unsaturated n-3 and n-6 fatty acids. Biochim Biophys Acta 2000;1486:219-31. 
[68]. Voss A, Reinhart M, Sankarappa S, Sprecher H. The metabolism of 7,10,13,16,19docosapentaenoic acid to 4,7,10,13,16,19-docosahexaenoic acid in rat liver is independent of a 4-desaturase. J Biol Chem 1991;266:19995-20000.

[69]. Gregory MK, Gibson RA, Cook-Johnson RJ, Cleland LG, James MJ. Elongase reactions as control points in long-chain polyunsaturated fatty acid synthesis. PLoS One 2011;6:e29662.

[70]. Whelan J, Gouffon J, Zhao Y. Effects of dietary stearidonic acid on biomarkers of lipid metabolism. J Nutr 2012;142:630S-34S.

[71]. Cho HP, Nakamura M, Clarke SD. Cloning, expression, and fatty acid regulation of the human delta-5 desaturase. J Biol Chem 1999;274:37335-9.

[72]. Matsuzaka T, Shimano H, Yahagi N, Amemiya-Kudo M, Yoshikawa T, Hasty AH, et al. Dual regulation of mouse Delta(5)- and Delta(6)-desaturase gene expression by SREBP-1 and PPARalpha. J Lipid Res 2002;43:107-14.

[73]. Lattka E, Illig T, Heinrich J, Koletzko B. Do FADS genotypes enhance our knowledge about fatty acid related phenotypes? Clin Nutr 2010;29:277-87.

[74]. Schaeffer L, Gohlke H, Muller M, Heid IM, Palmer LJ, Kompauer I, et al. Common genetic variants of the FADS1 FADS2 gene cluster and their reconstructed haplotypes are associated with the fatty acid composition in phospholipids. Hum Mol Genet 2006;15:1745-56.

[75]. Lattka E, Eggers S, Moeller G, Heim K, Weber M, Mehta D, et al. A common FADS2 promoter polymorphism increases promoter activity and facilitates binding of transcription factor ELK1. J Lipid Res 2010;51:182-91.

[76]. Reardon HT, Zhang J, Kothapalli KS, Kim AJ, Park WJ, Brenna JT. Insertion-deletions in a FADS2 intron 1 conserved regulatory locus control expression of fatty acid desaturases 1 and 2 and modulate response to simvastatin. Prostaglandins Leukot Essent Fatty Acids 2012;87:25-33.

[77]. Alsaleh A, Maniou Z, Lewis FJ, Hall WL, Sanders TA, O'Dell SD. ELOVL2 gene polymorphisms are associated with increases in plasma eicosapentaenoic and docosahexaenoic acid proportions after fish oil supplement. Genes Nutr 2014;9:362.

[78]. Tanaka T, Shen J, Abecasis GR, Kisialiou A, Ordovas JM, Guralnik JM, et al. Genome-wide association study of plasma polyunsaturated fatty acids in the InCHIANTI Study. PLoS Genet 2009;5:e1000338.

[79]. Devlin AM, Singh R, Wade RE, Innis SM, Bottiglieri T, Lentz SR. Hypermethylation of Fads2 and altered hepatic fatty acid and phospholipid metabolism in mice with hyperhomocysteinemia. J Biol Chem 2007;282:37082-90.

[80]. Niculescu MD, Lupu DS, Craciunescu CN. Maternal alpha-linolenic acid availability during gestation and lactation alters the postnatal hippocampal development in the mouse offspring. Int J Dev Neurosci 2011;29:795-802.

[81]. Hoile SP, Irvine NA, Kelsall CJ, Sibbons C, Feunteun A, Collister A, et al. Maternal fat intake in rats alters $20: 4 n-6$ and 22:6n-3 status and the epigenetic regulation of Fads 2 in offspring liver. J Nutr Biochem 2013;24:1213-20.

[82]. Kelsall CJ, Hoile SP, Irvine NA, Masoodi M, Torrens C, Lillycrop KA, et al. Vascular dysfunction induced in offspring by maternal dietary fat involves altered arterial polyunsaturated fatty acid biosynthesis. PLoS One 2012;7:e34492.

[83]. Howard TD, Mathias RA, Seeds MC, Herrington DM, Hixson JE, Shimmin LC, et al. DNA methylation in an enhancer region of the FADS cluster is associated with FADS activity in human liver. PLoS One 2014;9:e97510.

[84]. Cheatham CL, Lupu DS, Niculescu MD. Genetic and epigenetic transgenerational implications related to omega-3 fatty acids. Part II: maternal FADS2 rs174575 genotype and DNA methylation predict toddler cognitive performance. Nutr Res 2015;35:948-55.

[85]. Hoile SP, Clarke-Harris R, Huang RC, Calder PC, Mori TA, Beilin L, et al. Supplementation with $\mathrm{N}-3$ long-chain polyunsaturated fatty acids or olive oil in men and women with renal disease induces differential changes in the DNA methylation of FADS2 and ELOVL5 in peripheral blood mononuclear cells. PLoS One 2014;9:e109896. 
[86]. Malerba G, Schaeffer L, Xumerle L, Klopp N, Trabetti E, Biscuola M, et al. SNPs of the FADS gene cluster are associated with polyunsaturated fatty acids in a cohort of patients with cardiovascular disease. Lipids 2008;43:289-99.

[87]. Xie L, Innis SM. Genetic variants of the FADS1 FADS2 gene cluster are associated with altered $(n-6)$ and $(n-3)$ essential fatty acids in plasma and erythrocyte phospholipids in women during pregnancy and in breast milk during lactation. J Nutr 2008;138:2222-8.

[88]. Rzehak P, Thijs C, Standl M, Mommers M, Glaser C, Jansen E, et al. Variants of the FADS1 FADS2 gene cluster, blood levels of polyunsaturated fatty acids and eczema in children within the first 2 years of life. PLoS One 2010;5:e13261.

[89]. Molto-Puigmarti C, Plat J, Mensink RP, Muller A, Jansen E, Zeegers MP, et al. FADS1 FADS2 gene variants modify the association between fish intake and the docosahexaenoic acid proportions in human milk. Am J Clin Nutr 2010;91:1368-76.

[90]. Lattka E, Rzehak P, Szabo E, Jakobik V, Weck M, Weyermann M, et al. Genetic variants in the FADS gene cluster are associated with arachidonic acid concentrations of human breast milk at 1.5 and 6 mo postpartum and influence the course of milk dodecanoic, tetracosenoic, and trans-9-octadecenoic acid concentrations over the duration of lactation. Am J Clin Nutr 2011;93:382-91.

[91]. Morales E, Bustamante M, Gonzalez JR, Guxens M, Torrent M, Mendez M, et al. Genetic variants of the FADS gene cluster and ELOVL gene family, colostrums LC-PUFA levels, breastfeeding, and child cognition. PLoS One 2011;6:e17181.

[92]. Al-Hilal M, Alsaleh A, Maniou Z, Lewis FJ, Hall WL, Sanders TA, et al. Genetic variation at the FADS1-FADS2 gene locus influences delta- 5 desaturase activity and LC-PUFA proportions after fish oil supplement. J Lipid Res 2013;54:542-51.

[93]. Abdelmagid SA, Clarke SE, Roke K, Nielsen DE, Badawi A, El-Sohemy A, et al. Ethnicity, sex, FADS genetic variation, and hormonal contraceptive use influence delta-5- and delta-6-desaturase indices and plasma docosahexaenoic acid concentration in young Canadian adults: a crosssectional study. Nutr Metab (Lond) 2015;12:14.

[94]. Haghighi F, Galfalvy H, Chen S, Huang YY, Cooper TB, Burke AK, et al. DNA methylation perturbations in genes involved in polyunsaturated Fatty Acid biosynthesis associated with depression and suicide risk. Front Neurol 2015;6:92.

[95]. Moore SA. Polyunsaturated fatty acid synthesis and release by brain-derived cells in vitro. $J \mathrm{Mol}$ Neurosci 2001;16:195-200.

[96]. Monk JM, Liddle DM, Cohen DJ, Tsang DH, Hillyer LM, Abdelmagid SA, et al. The delta 6 desaturase knock out mouse reveals that immunomodulatory effects of essential n- 6 and n3 polyunsaturated fatty acids are both independent of and dependent upon conversion. $J$ Nutr Biochem 2016;32:29-38.

[97]. James MJ, Ursin VM, Cleland LG. Metabolism of stearidonic acid in human subjects: comparison with the metabolism of other n-3 fatty acids. Am J Clin Nutr 2003;77:1140-5.

[98]. Lemke SL, Vicini JL, Su H, Goldstein DA, Nemeth MA, Krul ES, et al. Dietary intake of stearidonic acid-enriched soybean oil increases the omega-3 index: randomized, double-blind clinical study of efficacy and safety. Am J Clin Nutr 2010;92:766-75.

[99]. Miles EA, Banerjee T, Dooper MM, M'Rabet L, Graus YM, Calder PC. The influence of different combinations of gamma-linolenic acid, stearidonic acid and EPA on immune function in healthy young male subjects. Br J Nutr 2004;91:893-903.

[100]. Krul ES, Lemke SL, Mukherjea R, Taylor ML, Goldstein DA, Su H, et al. Effects of duration of treatment and dosage of eicosapentaenoic acid and stearidonic acid on red blood cell eicosapentaenoic acid content. Prostaglandins Leukot Essent Fatty Acids 2012;86:51-9.

[101]. Arterburn LM, Hall EB, Oken H. Distribution, interconversion, and dose response of $n-3$ fatty acids in humans. Am J Clin Nutr 2006;83:1467S-76S.

[102]. Morris D. Metabolism of Alpha-linolenic acid. New Flax Facts. 
[103]. Harris WS. The omega-3 index as a risk factor for coronary heart disease. Am J Clin Nutr 2008;87:1997S-2002S.

[104]. Lemke SL, Maki KC, Hughes G, Taylor ML, Krul ES, Goldstein DA, et al. Consumption of stearidonic acid-rich oil in foods increases red blood cell eicosapentaenoic acid. J Acad Nutr Diet 2013;113:1044-56.

[105]. Pieters DJ, Mensink RP. Effects of stearidonic acid on serum triacylglycerol concentrations in overweight and obese subjects: a randomized controlled trial. Eur J Clin Nutr 2014;69:121-6.

[106]. Dittrich M, Jahreis G, Bothor K, Drechsel C, Kiehntopf M, Bluher M, et al. Benefits of foods supplemented with vegetable oils rich in alpha-linolenic, stearidonic or docosahexaenoic acid in hypertriglyceridemic subjects: a double-blind, randomized, controlled trail. Eur J Nutr 2014;54:881-93.

[107]. Kuhnt K, Fuhrmann C, Kohler M, Kiehntopf M, Jahreis G. Dietary echium oil increases longchain n-3 PUFAs, including docosapentaenoic acid, in blood fractions and alters biochemical markers for cardiovascular disease independently of age, sex, and metabolic syndrome. J Nutr 2014;144:447-60.

[108]. Emken EA, Adlof RO, Duval SM, Nelson GJ. Effect of dietary docosahexaenoic acid on desaturation and uptake in vivo of isotope-labeled oleic, linoleic, and linolenic acids by male subjects. Lipids 1999;34:785-91.

[109]. Salem N, Jr., Pawlosky R, Wegher B, Hibbeln J. In vivo conversion of linoleic acid to arachidonic acid in human adults. Prostaglandins Leukot Essent Fatty Acids 1999;60:407-10.

[110]. Pawlosky RJ, Hibbeln JR, Novotny JA, Salem N, Jr. Physiological compartmental analysis of alpha-linolenic acid metabolism in adult humans. J Lipid Res 2001;42:1257-65.

[111]. Hussein N, Ah-Sing E, Wilkinson P, Leach C, Griffin BA, Millward DJ. Long-chain conversion of [13C]linoleic acid and alpha-linolenic acid in response to marked changes in their dietary intake in men. J Lipid Res 2005;46:269-80.

[112]. Goyens PL, Spilker ME, Zock PL, Katan MB, Mensink RP. Compartmental modeling to quantify alpha-linolenic acid conversion after longer term intake of multiple tracer boluses. J Lipid Res 2005;46:1474-83.

[113]. Burdge GC. Metabolism of alpha-linolenic acid in humans. Prostaglandins Leukot Essent Fatty Acids 2006;75:161-8.

[114]. Emken EA. Stable isotope approaches, applications, and issues related to polyunsaturated fatty acid metabolism studies. Lipids 2001;36:965-73.

[115]. Pawlosky RJ, Hibbeln JR, Lin Y, Goodson S, Riggs P, Sebring N, et al. Effects of beef- and fishbased diets on the kinetics of $\mathrm{n}-3$ fatty acid metabolism in human subjects. Am J Clin Nutr 2003;77:565-72.

[116]. Pawlosky R, Hibbeln J, Lin Y, Salem N, Jr. n-3 fatty acid metabolism in women. Br J Nutr 2003;90:993-4.

[117]. Tang C, Cho HP, Nakamura MT, Clarke SD. Regulation of human delta- 6 desaturase gene transcription: identification of a functional direct repeat-1 element. J Lipid Res 2003;44:68695.

[118]. Lin YH, Llanos A, Mena P, Uauy R, Salem N, Jr., Pawlosky RJ. Compartmental analyses of 2H5alpha-linolenic acid and $\mathrm{C}-\mathrm{U}$-eicosapentaenoic acid toward synthesis of plasma labeled 22:6n-3 in newborn term infants. Am J Clin Nutr 2010;92:284-93.

[119]. Bemelmans WJ, Broer J, Feskens EJ, Smit AJ, Muskiet FA, Lefrandt JD, et al. Effect of an increased intake of alpha-linolenic acid and group nutritional education on cardiovascular risk factors: the Mediterranean Alpha-linolenic Enriched Groningen Dietary Intervention (MARGARIN) study. Am J Clin Nutr 2002;75:221-7.

[120]. Chan JK, Bruce VM, McDonald BE. Dietary alpha-linolenic acid is as effective as oleic acid and linoleic acid in lowering blood cholesterol in normolipidemic men. Am J Clin Nutr 1991;53:1230-4. 
[121]. Cunnane SC, Hamadeh MJ, Liede AC, Thompson LU, Wolever TM, Jenkins DJ. Nutritional attributes of traditional flaxseed in healthy young adults. Am J Clin Nutr 1995;61:62-8.

[122]. de Groot RH, Hornstra G, van Houwelingen AC, Roumen F. Effect of alpha-linolenic acid supplementation during pregnancy on maternal and neonatal polyunsaturated fatty acid status and pregnancy outcome. Am J Clin Nutr 2004;79:251-60.

[123]. Ezaki O, Takahashi M, Shigematsu T, Shimamura K, Kimura J, Ezaki H, et al. Long-term effects of dietary alpha-linolenic acid from perilla oil on serum fatty acids composition and on the risk factors of coronary heart disease in Japanese elderly subjects. J Nutr Sci Vitaminol (Tokyo) 1999;45:759-72.

[124]. Finnegan YE, Minihane AM, Leigh-Firbank EC, Kew S, Meijer GW, Muggli R, et al. Plant- and marine-derived $n-3$ polyunsaturated fatty acids have differential effects on fasting and postprandial blood lipid concentrations and on the susceptibility of LDL to oxidative modification in moderately hyperlipidemic subjects. Am J Clin Nutr 2003;77:783-95.

[125]. Francois CA, Connor SL, Bolewicz LC, Connor WE. Supplementing lactating women with flaxseed oil does not increase docosahexaenoic acid in their milk. Am J Clin Nutr 2003;77:226-33.

[126]. Freese R, Mutanen M, Valsta LM, Salminen I. Comparison of the effects of two diets rich in monounsaturated fatty acids differing in their linoleic/alpha-linolenic acid ratio on platelet aggregation. Thromb Haemost 1994;71:73-7.

[127]. Harper CR, Edwards MJ, DeFilippis AP, Jacobson TA. Flaxseed oil increases the plasma concentrations of cardioprotective (n-3) fatty acids in humans. J Nutr 2006;136:83-7.

[128]. Kelley DS, Nelson GJ, Love JE, Branch LB, Taylor PC, Schmidt PC, et al. Dietary alpha-linolenic acid alters tissue fatty acid composition, but not blood lipids, lipoproteins or coagulation status in humans. Lipids 1993;28:533-7.

[129]. Li D, Sinclair A, Wilson A, Nakkote S, Kelly F, Abedin L, et al. Effect of dietary alpha-linolenic acid on thrombotic risk factors in vegetarian men. Am J Clin Nutr 1999;69:872-82.

[130]. Mantzioris E, James MJ, Gibson RA, Cleland LG. Dietary substitution with an alpha-linolenic acid-rich vegetable oil increases eicosapentaenoic acid concentrations in tissues. Am J Clin Nutr 1994;59:1304-9.

[131]. Sanders TA, Younger KM. The effect of dietary supplements of omega 3 polyunsaturated fatty acids on the fatty acid composition of platelets and plasma choline phosphoglycerides. $\mathrm{Br} \mathrm{J}$ Nutr 1981;45:613-6.

[132]. Wallace FA, Miles EA, Calder PC. Comparison of the effects of linseed oil and different doses of fish oil on mononuclear cell function in healthy human subjects. Br J Nutr 2003;89:679-89.

[133]. Zhao G, Etherton TD, Martin KR, Gillies PJ, West SG, Kris-Etherton PM. Dietary alpha-linolenic acid inhibits proinflammatory cytokine production by peripheral blood mononuclear cells in hypercholesterolemic subjects. Am J Clin Nutr 2007;85:385-91.

[134]. Zhao G, Etherton TD, Martin KR, West SG, Gillies PJ, Kris-Etherton PM. Dietary alpha-linolenic acid reduces inflammatory and lipid cardiovascular risk factors in hypercholesterolemic men and women. J Nutr 2004;134:2991-7.

[135]. Austria JA, Richard MN, Chahine MN, Edel AL, Malcolmson L, Dupasquier CM, et al. Bioavailability of alpha-linolenic acid in subjects after ingestion of three different forms of flaxseed. J Am Coll Nutr 2008;27:214-21.

[136]. Barden AE, Croft KD, Durand T, Guy A, Mueller MJ, Mori TA. Flaxseed oil supplementation increases plasma F1-phytoprostanes in healthy men. J Nutr 2009;139:1890-5.

[137]. Bloedon LT, Balikai S, Chittams J, Cunnane SC, Berlin JA, Rader DJ, et al. Flaxseed and cardiovascular risk factors: results from a double blind, randomized, controlled clinical trial. J Am Coll Nutr 2008;27:65-74.

[138]. Chiang YL, Haddad E, Rajaram S, Shavlik D, Sabate J. The effect of dietary walnuts compared to fatty fish on eicosanoids, cytokines, soluble endothelial adhesion molecules and lymphocyte 
subsets: a randomized, controlled crossover trial. Prostaglandins Leukot Essent Fatty Acids 2012;87:111-7.

[139]. Dodin S, Cunnane SC, Masse B, Lemay A, Jacques H, Asselin G, et al. Flaxseed on cardiovascular disease markers in healthy menopausal women: a randomized, double-blind, placebo-controlled trial. Nutrition 2008;24:23-30.

[140]. Egert S, Kannenberg F, Somoza V, Erbersdobler HF, Wahrburg U. Dietary alpha-linolenic acid, EPA, and DHA have differential effects on LDL fatty acid composition but similar effects on serum lipid profiles in normolipidemic humans. J Nutr 2009;139:861-8.

[141]. Geleijnse JM, Giltay EJ, Kromhout D. Effects of n-3 fatty acids on cognitive decline: a randomized, double-blind, placebo-controlled trial in stable myocardial infarction patients. Alzheimers Dement 2012;8:278-87.

[142]. Hutchins AM, Brown BD, Cunnane SC, Domitrovich SG, Adams ER, Bobowiec CE. Daily flaxseed consumption improves glycemic control in obese men and women with pre-diabetes: a randomized study. Nutr Res 2013;33:367-75.

[143]. Kaul N, Kreml R, Austria JA, Richard MN, Edel AL, Dibrov E, et al. A comparison of fish oil, flaxseed oil and hempseed oil supplementation on selected parameters of cardiovascular health in healthy volunteers. J Am Coll Nutr 2008;27:51-8.

[144]. Patenaude A, Rodriguez-Leyva D, Edel AL, Dibrov E, Dupasquier CM, Austria JA, et al. Bioavailability of alpha-linolenic acid from flaxseed diets as a function of the age of the subject. Eur J Clin Nutr 2009;63:1123-9.

[145]. Pintus S, Murru E, Carta G, Cordeddu L, Batetta B, Accossu S, et al. Sheep cheese naturally enriched in alpha-linolenic, conjugated linoleic and vaccenic acids improves the lipid profile and reduces anandamide in the plasma of hypercholesterolaemic subjects. Br J Nutr 2013;109:1453-62.

[146]. Ristic-Medic D, Perunicic-Pekovic G, Rasic-Milutinovic Z, Takic M, Popovic T, Arsic A, et al. Effects of dietary milled seed mixture on fatty acid status and inflammatory markers in patients on hemodialysis. Scientific World J 2014;2014:563576.

[147]. Rodriguez-Leyva D, Weighell W, Edel AL, LaVallee R, Dibrov E, Pinneker R, et al. Potent antihypertensive action of dietary flaxseed in hypertensive patients. Hypertension 2013;62:1081-9.

[148]. Taylor CG, Noto AD, Stringer DM, Froese S, Malcolmson L. Dietary milled flaxseed and flaxseed oil improve N-3 fatty acid status and do not affect glycemic control in individuals with wellcontrolled type 2 diabetes. J Am Coll Nutr 2010;29:72-80.

[149]. West SG, Krick AL, Klein LC, Zhao G, Wojtowicz TF, McGuiness M, et al. Effects of diets high in walnuts and flax oil on hemodynamic responses to stress and vascular endothelial function. $J$ Am Coll Nutr 2010;29:595-603.

[150]. Allman MA, Pena MM, Pang D. Supplementation with flaxseed oil versus sunflowerseed oil in healthy young men consuming a low fat diet: effects on platelet composition and function. Eur J Clin Nutr 1995;49:169-78.

[151]. Allman-Farinelli MA, Hall D, Kingham K, Pang D, Petocz P, Favaloro EJ. Comparison of the effects of two low fat diets with different alpha-linolenic:linoleic acid ratios on coagulation and fibrinolysis. Atherosclerosis 1999;142:159-68.

[152]. Caughey GE, Mantzioris E, Gibson RA, Cleland LG, James MJ. The effect on human tumor necrosis factor alpha and interleukin 1 beta production of diets enriched in $n-3$ fatty acids from vegetable oil or fish oil. Am J Clin Nutr 1996;63:116-22.

[153]. Healy DA, Wallace FA, Miles EA, Calder PC, Newsholm P. Effect of low-to-moderate amounts of dietary fish oil on neutrophil lipid composition and function. Lipids 2000;35:763-8.

[154]. Kew S, Banerjee T, Minihane AM, Finnegan YE, Muggli R, Albers R, et al. Lack of effect of foods enriched with plant- or marine-derived n-3 fatty acids on human immune function. Am J Clin Nutr 2003;77:1287-95. 
[155]. Kwon JS, Snook JT, Wardlaw GM, Hwang DH. Effects of diets high in saturated fatty acids, canola oil, or safflower oil on platelet function, thromboxane B2 formation, and fatty acid composition of platelet phospholipids. Am J Clin Nutr 1991;54:351-8.

[156]. Mutanen M, Freese R, Valsta LM, Ahola I, Ahlstrom A. Rapeseed oil and sunflower oil diets enhance platelet in vitro aggregation and thromboxane production in healthy men when compared with milk fat or habitual diets. Thromb Haemost 1992;67:352-6.

[157]. Nelson TL, Stevens JR, Hickey MS. Inflammatory markers are not altered by an eight week dietary alpha-linolenic acid intervention in healthy abdominally obese adult males and females. Cytokine 2007;38:101-6.

[158]. Sanders TA, Roshanai F. The influence of different types of omega 3 polyunsaturated fatty acids on blood lipids and platelet function in healthy volunteers. Clin Sci (Lond) 1983;64:91-9.

[159]. Weaver BJ, Corner EJ, Bruce VM, McDonald BE, Holub BJ. Dietary canola oil: effect on the accumulation of eicosapentaenoic acid in the alkenylacyl fraction of human platelet ethanolamine phosphoglyceride. Am J Clin Nutr 1990;51:594-8.

[160]. Wilkinson P, Leach C, Ah-Sing EE, Hussain N, Miller GJ, Millward DJ, et al. Influence of alphalinolenic acid and fish-oil on markers of cardiovascular risk in subjects with an atherogenic lipoprotein phenotype. Atherosclerosis 2005;181:115-24.

[161]. Dewell A, Marvasti FF, Harris WS, Tsao P, Gardner CD. Low- and high-dose plant and marine $(n-3)$ fatty acids do not affect plasma inflammatory markers in adults with metabolic syndrome. J Nutr 2011;141:2166-71.

[162]. Egert S, Lindenmeier M, Harnack K, Krome K, Erbersdobler HF, Wahrburg U, et al. Margarines fortified with alpha-linolenic acid, eicosapentaenoic acid, or docosahexaenoic acid alter the fatty acid composition of erythrocytes but do not affect the antioxidant status of healthy adults. J Nutr 2012;142:1638-44.

[163]. Kontogianni MD, Vlassopoulos A, Gatzieva A, Farmaki AE, Katsiougiannis S, Panagiotakos DB, et al. Flaxseed oil does not affect inflammatory markers and lipid profile compared to olive oil, in young, healthy, normal weight adults. Metabolism 2013;62:686-93.

[164]. Rajaram S, Haddad EH, Mejia A, Sabate J. Walnuts and fatty fish influence different serum lipid fractions in normal to mildly hyperlipidemic individuals: a randomized controlled study. Am J Clin Nutr 2009;89:1657S-63S.

[165]. Arm JP, Boyce JA, Wang L, Chhay H, Zahid M, Patil V, et al. Impact of botanical oils on polyunsaturated fatty acid metabolism and leukotriene generation in mild asthmatics. Lipids Health Dis 2013;12:141.

[166]. Harris WS, Lemke SL, Hansen SN, Goldstein DA, DiRienzo MA, Su H, et al. Stearidonic acidenriched soybean oil increased the omega-3 index, an emerging cardiovascular risk marker. Lipids 2008;43:805-11.

[167]. Miles EA, Banerjee T, Calder PC. The influence of different combinations of gamma-linolenic, stearidonic and eicosapentaenoic acids on the fatty acid composition of blood lipids and mononuclear cells in human volunteers. Prostaglandins Leukot Essent Fatty Acids 2004;70:529-38.

[168]. Han SN, Lichtenstein AH, Ausman LM, Meydani SN. Novel soybean oils differing in fatty acid composition alter immune functions of moderately hypercholesterolemic older adults. J Nutr 2012;142:2182-7.

[169]. Chan JK, McDonald BE, Gerrard JM, Bruce VM, Weaver BJ, Holub BJ. Effect of dietary alphalinolenic acid and its ratio to linoleic acid on platelet and plasma fatty acids and thrombogenesis. Lipids 1993;28:811-7.

[170]. Schwartz J, Dube K, Sichert-Hellert W, Kannenberg F, Kunz C, Kalhoff H, et al. Modification of dietary polyunsaturated fatty acids via complementary food enhances $n-3$ long-chain polyunsaturated fatty acid synthesis in healthy infants: a double blinded randomised controlled trial. Arch Dis Child 2009;94:876-82. 
[171]. Gracious BL, Chirieac MC, Costescu S, Finucane TL, Youngstrom EA, Hibbeln JR. Randomized, placebo-controlled trial of flax oil in pediatric bipolar disorder. Bipolar Disord 2010;12:14254.

[172]. Sauerwald TU, Hachey DL, Jensen CL, Chen H, Anderson RE, Heird WC. Effect of dietary alphalinolenic acid intake on incorporation of docosahexaenoic and arachidonic acids into plasma phospholipids of term infants. Lipids 1996;31:S131-5.

[173]. Clark KJ, Makrides M, Neumann MA, Gibson RA. Determination of the optimal ratio of linoleic acid to alpha-linolenic acid in infant formulas. J Pediatr 1992;120:S151-8.

[174]. Jensen CL, Chen H, Fraley JK, Anderson RE, Heird WC. Biochemical effects of dietary linoleic/alpha-linolenic acid ratio in term infants. Lipids 1996;31:107-13.

[175]. Brenna JT. Efficiency of conversion of alpha-linolenic acid to long chain $n-3$ fatty acids in man. Curr Opin Clin Nutr Metab Care 2002;5:127-32.

[176]. Lohner S, Fekete K, Marosvolgyi T, Decsi T. Gender differences in the long-chain polyunsaturated fatty acid status: systematic review of 51 publications. Ann Nutr Metab 2013;62:98-112.

[177]. Childs CE, Kew S, Finnegan YE, Minihane AM, Leigh-Firbank EC, Williams CM, et al. Increased dietary alpha-linolenic acid has sex-specific effects upon eicosapentaenoic acid status in humans: re-examination of data from a randomised, placebo-controlled, parallel study. Nutr J 2014;13:113.

[178]. Ottosson UB, Lagrelius A, Rosing U, von Schoultz B. Relative fatty acid composition of lecithin during postmenopausal replacement therapy--a comparison between ethinyl estradiol and estradiol valerate. Gynecol Obstet Invest 1984;18:296-302.

[179]. Giltay EJ, Gooren LJ, Toorians AW, Katan MB, Zock PL. Docosahexaenoic acid concentrations are higher in women than in men because of estrogenic effects. Am J Clin Nutr 2004;80:1167-74.

[180]. Kris-Etherton PM, Harris WS, Appel U, American Heart Association. Nutrition C. Fish consumption, fish oil, omega-3 fatty acids, and cardiovascular disease. Circulation 2002;106:2747-57.

[181]. He K, Rimm EB, Merchant A, Rosner BA, Stampfer MJ, Willett WC, et al. Fish consumption and risk of stroke in men. JAMA 2002;288:3130-6.

[182]. Shoda R, Matsueda K, Yamato S, Umeda N. Epidemiologic analysis of Crohn disease in Japan: increased dietary intake of $n-6$ polyunsaturated fatty acids and animal protein relates to the increased incidence of Crohn disease in Japan. Am J Clin Nutr 1996;63:741-5.

[183]. Pischon T, Hankinson SE, Hotamisligil GS, Rifai N, Willett WC, Rimm EB. Habitual dietary intake of $n-3$ and $n-6$ fatty acids in relation to inflammatory markers among US men and women. Circulation 2003;108:155-60.

[184]. Lopez-Garcia E, Schulze MB, Fung TT, Meigs JB, Rifai N, Manson JE, et al. Major dietary patterns are related to plasma concentrations of markers of inflammation and endothelial dysfunction. Am J Clin Nutr 2004;80:1029-35.

[185]. Rangel-Huerta OD, Aguilera CM, Mesa MD, Gil A. Omega-3 long-chain polyunsaturated fatty acids supplementation on inflammatory biomakers: a systematic review of randomised clinical trials. Br J Nutr 2012;107:S159-70.

[186]. Harris WS. n-3 fatty acids and lipoproteins: comparison of results from human and animal studies. Lipids 1996;31:243-52.

[187]. Roche HM, Gibney MJ. Long-chain n-3 polyunsaturated fatty acids and triacylglycerol metabolism in the postprandial state. Lipids 1999;34:S259-65.

[188]. Williams CM. Postprandial lipid metabolism: effects of dietary fatty acids. Proc Nutr Soc 1997;56:679-92.

[189]. Geleijnse JM, Giltay EJ, Grobbee DE, Donders AR, Kok FJ. Blood pressure response to fish oil supplementation: metaregression analysis of randomized trials. J Hypertens 2002;20:1493-9. 
[190]. Harris WS, Connor WE, Goodnight SH, Jr. Dietary fish oils, plasma lipids and platelets in man. Prog Lipid Res 1981;20:75-9.

[191]. von Schacky C, Fischer S, Weber PC. Long-term effects of dietary marine omega-3 fatty acids upon plasma and cellular lipids, platelet function, and eicosanoid formation in humans. $J$ Clin Invest 1985;76:1626-31.

[192]. Miller GJ. Dietary fatty acids and blood coagulation. Prostaglandins Leukot Essent Fatty Acids 1997;57:389-94.

[193]. Christensen JH, Gustenhoff P, Korup E, Aaroe J, Toft E, Moller J, et al. Effect of fish oil on heart rate variability in survivors of myocardial infarction: a double blind randomised controlled trial. BMJ 1996;312:677-8.

[194]. Christensen JH, Skou HA, Fog L, Hansen V, Vesterlund T, Dyerberg J, et al. Marine n-3 fatty acids, wine intake, and heart rate variability in patients referred for coronary angiography. Circulation 2001;103:651-7.

[195]. Schrepf R, Limmert T, Claus Weber P, Theisen K, Sellmayer A. Immediate effects of n-3 fatty acid infusion on the induction of sustained ventricular tachycardia. Lancet 2004;363:1441-2.

[196]. Chin JP, Dart AM. How do fish oils affect vascular function? Clin Exp Pharmacol Physiol 1995;22:71-81.

[197]. McVeigh GE, Brennan GM, Cohn JN, Finkelstein SM, Hayes RJ, Johnston GD. Fish oil improves arterial compliance in non-insulin-dependent diabetes mellitus. Arterioscler Thromb 1994;14:1425-9.

[198]. Goode GK, Garcia S, Heagerty AM. Dietary supplementation with marine fish oil improves in vitro small artery endothelial function in hypercholesterolemic patients: a double-blind placebo-controlled study. Circulation 1997;96:2802-7.

[199]. Tagawa H, Shimokawa H, Tagawa T, Kuroiwa-Matsumoto M, Hirooka Y, Takeshita A. Longterm treatment with eicosapentaenoic acid augments both nitric oxide-mediated and nonnitric oxide-mediated endothelium-dependent forearm vasodilatation in patients with coronary artery disease. J Cardiovasc Pharmacol 1999;33:633-40.

[200]. Calder PC. Polyunsaturated fatty acids, inflammation, and immunity. Lipids 2001;36:1007-24.

[201]. Calder PC. Dietary modification of inflammation with lipids. Proc Nutr Soc 2002;61:345-58.

[202]. Calder PC. N-3 polyunsaturated fatty acids and inflammation: from molecular biology to the clinic. Lipids 2003;38:343-52.

[203]. Calder PC. Polyunsaturated fatty acids and inflammation. Biochem Soc Trans 2005;33:423-7.

[204]. Calder PC. n-3 fatty acids, inflammation and immunity: new mechanisms to explain old actions. Proc Nutr Soc 2013;72:326-36.

[205]. Suzukawa M, Abbey M, Howe PR, Nestel PJ. Effects of fish oil fatty acids on low density lipoprotein size, oxidizability, and uptake by macrophages. J Lipid Res 1995;36:473-84.

[206]. Sorensen NS, Marckmann P, Hoy CE, van Duyvenvoorde W, Princen HM. Effect of fish-oilenriched margarine on plasma lipids, low-density-lipoprotein particle composition, size, and susceptibility to oxidation. Am J Clin Nutr 1998;68:235-41.

[207]. Baylin A, Kabagambe EK, Ascherio A, Spiegelman D, Campos H. Adipose tissue alpha-linolenic acid and nonfatal acute myocardial infarction in Costa Rica. Circulation 2003;107:1586-91.

[208]. Campos H, Baylin A, Willett WC. Alpha-linolenic acid and risk of nonfatal acute myocardial infarction. Circulation 2008;118:339-45.

[209]. Dolecek TA. Epidemiological evidence of relationships between dietary polyunsaturated fatty acids and mortality in the multiple risk factor intervention trial. Proc Soc Exp Biol Med 1992;200:177-82.

[210]. Hu FB, Stampfer MJ, Manson JE, Rimm EB, Wolk A, Colditz GA, et al. Dietary intake of alphalinolenic acid and risk of fatal ischemic heart disease among women. Am J Clin Nutr 1999;69:890-7. 
[211]. Ascherio A, Rimm EB, Giovannucci EL, Spiegelman D, Stampfer M, Willett WC. Dietary fat and risk of coronary heart disease in men: cohort follow up study in the United States. BMJ 1996;313:84-90.

[212]. Djousse L, Pankow JS, Eckfeldt JH, Folsom AR, Hopkins PN, Province MA, et al. Relation between dietary linolenic acid and coronary artery disease in the National Heart, Lung, and Blood Institute Family Heart Study. Am J Clin Nutr 2001;74:612-9.

[213]. Brouwer IA, Katan MB, Zock PL. Dietary alpha-linolenic acid is associated with reduced risk of fatal coronary heart disease, but increased prostate cancer risk: a meta-analysis. J Nutr 2004;134:919-22.

[214]. Pan A, Chen M, Chowdhury R, Wu JH, Sun Q, Campos H, et al. alpha-Linolenic acid and risk of cardiovascular disease: a systematic review and meta-analysis. Am J Clin Nutr 2012;96:126273.

[215]. Wendland E, Farmer A, Glasziou P, Neil A. Effect of alpha linolenic acid on cardiovascular risk markers: a systematic review. Heart 2006;92:166-9.

[216]. Oomen CM, Ocke MC, Feskens EJ, Kok FJ, Kromhout D. alpha-Linolenic acid intake is not beneficially associated with 10-y risk of coronary artery disease incidence: the Zutphen Elderly Study. Am J Clin Nutr 2001;74:457-63.

[217]. Simon JA, Fong J, Bernert JT, Jr., Browner WS. Serum fatty acids and the risk of stroke. Stroke 1995;26:778-82.

[218]. Vedtofte MS, Jakobsen MU, Lauritzen L, Heitmann BL. Dietary alpha-linolenic acid, linoleic acid, and n-3 long-chain PUFA and risk of ischemic heart disease. Am J Clin Nutr 2011;94:1097-103.

[219]. Lemaitre RN, Sitlani C, Song X, King IB, McKnight B, Spiegelman D, et al. Circulating and dietary alpha-linolenic acid and incidence of congestive heart failure in older adults: the Cardiovascular Health Study. Am J Clin Nutr 2012;96:269-74.

[220]. de Goede J, Verschuren WM, Boer JM, Verberne LD, Kromhout D, Geleijnse JM. N-6 and N-3 fatty acid cholesteryl esters in relation to fatal $\mathrm{CHD}$ in a Dutch adult population: a nested case-control study and meta-analysis. PLoS One 2013;8:e59408.

[221]. Harris WS, Poston WC, Haddock CK. Tissue n-3 and n-6 fatty acids and risk for coronary heart disease events. Atherosclerosis 2007;193:1-10.

[222]. de Lorgeril M, Renaud S, Mamelle N, Salen P, Martin JL, Monjaud I, et al. Mediterranean alpha-linolenic acid-rich diet in secondary prevention of coronary heart disease. Lancet 1994;343:1454-9.

[223]. de Lorgeril M, Salen P, Martin JL, Monjaud I, Delaye J, Mamelle N. Mediterranean diet, traditional risk factors, and the rate of cardiovascular complications after myocardial infarction: final report of the Lyon Diet Heart Study. Circulation 1999;99:779-85.

[224]. Fleming JA, Kris-Etherton PM. The evidence for alpha-linolenic acid and cardiovascular disease benefits: comparisons with eicosapentaenoic acid and docosahexaenoic acid. Adv Nutr 2014;5:863S-76S.

[225]. Kromhout D, Giltay EJ, Geleijnse JM, Alpha Omega Trial G. n-3 fatty acids and cardiovascular events after myocardial infarction. N Engl J Med 2010;363:2015-26.

[226]. Katan MB, Zock PL, Mensink RP. Dietary oils, serum lipoproteins, and coronary heart disease. Am J Clin Nutr 1995;61:1368S-73S.

[227]. Arjmandi BH, Khan DA, Juma S, Drum ML, Venkatesh S, Sohn E, et al. Whole flaxseed consumption lowers serum LDL-cholesterol and lipoprotein(a) concentrations in postmenopausal women. Nutr Res 1998;18:1203-14.

[228]. Freese R, Mutanen M. Alpha-linolenic acid and marine long-chain $n-3$ fatty acids differ only slightly in their effects on hemostatic factors in healthy subjects. Am J Clin Nutr 1997;66:5918.

[229]. Kestin M, Clifton P, Belling GB, Nestel PJ. n-3 fatty acids of marine origin lower systolic blood pressure and triglycerides but raise LDL cholesterol compared with $n-3$ and $n-6$ fatty acids from plants. Am J Clin Nutr 1990;51:1028-34. 
[230]. Layne KS, Goh YK, Jumpsen JA, Ryan EA, Chow P, Clandinin MT. Normal subjects consuming physiological levels of 18:3(n-3) and 20:5(n-3) from flaxseed or fish oils have characteristic differences in plasma lipid and lipoprotein fatty acid levels. J Nutr 1996;126:2130-40.

[231]. Nestel PJ, Pomeroy SE, Sasahara T, Yamashita T, Liang YL, Dart AM, et al. Arterial compliance in obese subjects is improved with dietary plant n-3 fatty acid from flaxseed oil despite increased LDL oxidizability. Arterioscler Thromb Vasc Biol 1997;17:1163-70.

[232]. Pang D, Allman-Farinelli MA, Wong T, Barnes R, Kingham KM. Replacement of linoleic acid with alpha-linolenic acid does not alter blood lipids in normolipidaemic men. Br J Nutr 1998;80:163-7.

[233]. Singer P, Berger I, Wirth M, Godicke W, Jaeger W, Voigt S. Slow desaturation and elongation of linoleic and alpha-linolenic acids as a rationale of eicosapentaenoic acid-rich diet to lower blood pressure and serum lipids in normal, hypertensive and hyperlipemic subjects. Prostaglandins Leukot Med 1986;24:173-93.

[234]. Finnegan YE, Howarth D, Minihane AM, Kew S, Miller GJ, Calder PC, et al. Plant and marine derived $(n-3)$ polyunsaturated fatty acids do not affect blood coagulation and fibrinolytic factors in moderately hyperlipidemic humans. J Nutr 2003;133:2210-3.

[235]. Junker R, Kratz M, Neufeld M, Erren M, Nofer JR, Schulte $H$, et al. Effects of diets containing olive oil, sunflower oil, or rapeseed oil on the hemostatic system. Thromb Haemost 2001;85:280-6.

[236]. Karvonen HM, Aro A, Tapola NS, Salminen I, Uusitupa MI, Sarkkinen ES. Effect of alphalinolenic acid-rich Camelina sativa oil on serum fatty acid composition and serum lipids in hypercholesterolemic subjects. Metabolism 2002;51:1253-60.

[237]. Sodergren E, Gustafsson IB, Basu S, Nourooz-Zadeh J, Nalsen C, Turpeinen A, et al. A diet containing rapeseed oil-based fats does not increase lipid peroxidation in humans when compared to a diet rich in saturated fatty acids. Eur J Clin Nutr 2001;55:922-31.

[238]. Faintuch J, Horie LM, Barbeiro HV, Barbeiro DF, Soriano FG, Ishida RK, et al. Systemic inflammation in morbidly obese subjects: response to oral supplementation with alphalinolenic acid. Obes Surg 2007;17:341-7.

[239]. Paschos GK, Zampelas A, Panagiotakos DB, Katsiougiannis S, Griffin BA, Votteas V, et al. Effects of flaxseed oil supplementation on plasma adiponectin levels in dyslipidemic men. Eur J Nutr 2007;46:315-20.

[240]. Rallidis LS, Paschos G, Liakos GK, Velissaridou AH, Anastasiadis G, Zampelas A. Dietary alphalinolenic acid decreases $C$-reactive protein, serum amyloid $A$ and interleukin- 6 in dyslipidaemic patients. Atherosclerosis 2003;167:237-42.

[241]. Din JN, Aftab SM, Jubb AW, Carnegy FH, Lyall K, Sarma J, et al. Effect of moderate walnut consumption on lipid profile, arterial stiffness and platelet activation in humans. Eur J Clin Nutr 2011;65:234-9.

[242]. Gladine C, Meunier N, Blot A, Bruchet L, Pages X, Gaud M, et al. Preservation of micronutrients during rapeseed oil refining: a tool to optimize the health value of edible vegetable oils? Rationale and design of the Optim'Oils randomized clinical trial. Contemp Clin Trials 2011;32:233-9.

[243]. Baxheinrich A, Stratmann B, Lee-Barkey YH, Tschoepe D, Wahrburg U. Effects of a rapeseed oil-enriched hypoenergetic diet with a high content of alpha-linolenic acid on body weight and cardiovascular risk profile in patients with the metabolic syndrome. Br J Nutr 2012;108:682-91.

[244]. Khalatbari Soltani S, Jamaluddin R, Tabibi H, Mohd Yusof BN, Atabak S, Loh SP, et al. Effects of flaxseed consumption on systemic inflammation and serum lipid profile in hemodialysis patients with lipid abnormalities. Hemodial Int 2013;17:275-81.

[245]. Goyens PL, Mensink RP. Effects of alpha-linolenic acid versus those of EPA/DHA on cardiovascular risk markers in healthy elderly subjects. Eur J Clin Nutr 2006;60:978-84. 
[246]. Shearer GC, Savinova OV, Harris WS. Fish oil -- how does it reduce plasma triglycerides? Biochim Biophys Acta 2012;1821:843-51.

[247]. Harris WS. n-3 fatty acids and serum lipoproteins: human studies. Am J Clin Nutr 1997;65:1645S-54S.

[248]. Lichtenstein AH, Ausman LM, Carrasco W, Jenner JL, Gualtieri L, Goldin BR, et al. Effects of canola, corn, and olive oils on fasting and postprandial plasma lipoproteins in humans as part of a National Cholesterol Education Program Step 2 diet. Arterioscler Thromb 1993;13:1533-42.

[249]. Berry EM, Hirsch J. Does dietary linolenic acid influence blood pressure? Am J Clin Nutr 1986;44:336-40.

[250]. Salonen JT, Salonen R, Ihanainen M, Parviainen M, Seppanen R, Kantola M, et al. Blood pressure, dietary fats, and antioxidants. Am J Clin Nutr 1988;48:1226-32.

[251]. Caligiuri SP, Aukema HM, Ravandi A, Guzman R, Dibrov E, Pierce GN. Flaxseed consumption reduces blood pressure in patients with hypertension by altering circulating oxylipins via an alpha-linolenic acid-induced inhibition of soluble epoxide hydrolase. Hypertension 2014;64:53-9.

[252]. Appel L, Miller ER, 3rd, Seidler AJ, Whelton PK. Does supplementation of diet with 'fish oil' reduce blood pressure? A meta-analysis of controlled clinical trials. Arch Intern Med 1993;153:1429-38.

[253]. Morris MC, Sacks F, Rosner B. Does fish oil lower blood pressure? A meta-analysis of controlled trials. Circulation 1993;88:523-33.

[254]. Miller PE, Van Elswyk M, Alexander DD. Long-chain omega-3 fatty acids eicosapentaenoic acid and docosahexaenoic acid and blood pressure: a meta-analysis of randomized controlled trials. Am J Hypertens 2014;27:885-96.

[255]. Needleman P, Wyche A, Raz A. Platelet and blood vessel arachidonate metabolism and interactions. J Clin Invest 1979;63:345-9.

[256]. Knapp HR, Reilly IA, Alessandrini P, FitzGerald GA. In vivo indexes of platelet and vascular function during fish-oil administration in patients with atherosclerosis. $N$ Eng/ J Med 1986;314:937-42.

[257]. Egert S, Baxheinrich A, Lee-Barkey YH, Tschoepe D, Wahrburg U, Stratmann B. Effects of an energy-restricted diet rich in plant-derived alpha-linolenic acid on systemic inflammation and endothelial function in overweight-to-obese patients with metabolic syndrome traits. $\mathrm{Br}$ J Nutr 2014;112:1315-22.

[258]. Calder PC. Marine omega-3 fatty acids and inflammatory processes: Effects, mechanisms and clinical relevance. Biochim Biophys Acta 2015;1851:469-84.

[259]. Pearson TA, Mensah GA, Alexander RW, Anderson JL, Cannon RO, 3rd, Criqui M, et al. Markers of inflammation and cardiovascular disease: application to clinical and public health practice: A statement for healthcare professionals from the Centers for Disease Control and Prevention and the American Heart Association. Circulation 2003;107:499-511.

[260]. Hu FB, Cho E, Rexrode KM, Albert CM, Manson JE. Fish and long-chain omega-3 fatty acid intake and risk of coronary heart disease and total mortality in diabetic women. Circulation 2003;107:1852-7.

[261]. Bemelmans WJ, Lefrandt JD, Feskens EJ, van Haelst PL, Broer J, Meyboom-de Jong B, et al. Increased alpha-linolenic acid intake lowers $\mathrm{C}$-reactive protein, but has no effect on markers of atherosclerosis. Eur J Clin Nutr 2004;58:1083-9.

[262]. Thies F, Miles EA, Nebe-von-Caron G, Powell JR, Hurst TL, Newsholme EA, et al. Influence of dietary supplementation with long-chain $n-3$ or $n-6$ polyunsaturated fatty acids on blood inflammatory cell populations and functions and on plasma soluble adhesion molecules in healthy adults. Lipids 2001;36:1183-93. 
[263]. Paschos GK, Rallidis LS, Liakos GK, Panagiotakos D, Anastasiadis G, Votteas V, et al. Background diet influences the anti-inflammatory effect of alpha-linolenic acid in dyslipidaemic subjects. Br J Nutr 2004;92:649-55.

[264]. Caligiuri SP, Aukema HM, Ravandi A, Pierce GN. Elevated levels of pro-inflammatory oxylipins in older subjects are normalized by flaxseed consumption. Exp Gerontol 2014;59:51-7.

[265]. Kelley DS, Branch LB, Love JE, Taylor PC, Rivera YM, lacono JM. Dietary alpha-linolenic acid and immunocompetence in humans. Am J Clin Nutr 1991;53:40-6.

[266]. Thies F, Nebe-von-Caron G, Powell JR, Yaqoob P, Newsholme EA, Calder PC. Dietary supplementation with gamma-linolenic acid or fish oil decreases T lymphocyte proliferation in healthy older humans. J Nutr 2001;131:1918-27.

[267]. Thies F, Nebe-von-Caron G, Powell JR, Yaqoob P, Newsholme EA, Calder PC. Dietary supplementation with eicosapentaenoic acid, but not with other long-chain $n-3$ or $n-6$ polyunsaturated fatty acids, decreases natural killer cell activity in healthy subjects aged $>55$ y. Am J Clin Nutr 2001;73:539-48.

[268]. Walker CG, Jebb SA, Calder PC. Stearidonic acid as a supplemental source of omega-3 polyunsaturated fatty acids to enhance status for improved human health. Nutrition 2013;29:363-9.

[269]. De Spirt S, Stahl W, Tronnier H, Sies H, Bejot M, Maurette JM, et al. Intervention with flaxseed and borage oil supplements modulates skin condition in women. Br J Nutr 2009;101:440-5. 


\section{Figure legends}

Figure 1. The pathway of metabolic conversion of alpha-linolenic acid to longer-chain $\omega-3$ polyunsaturated fatty acids. Genes encoding the various enzymes are shown in parentheses.

Figure 2. Overview of the main metabolic fates of alpha-linolenic acid in humans. DHA docosahexaenoic acid; DPA, docosapentaenoic acid; EPA eicosapentaenoic acid.

Figure 3. EPA, DPA and DHA in plasma phospholipid (A) and RBC phospholipid (B) before and after 6 weeks of ALA treatment. Data are mean + SD and are taken from James et al. [97]

Figure 4. Change in plasma phospholipid EPA (A), DPA (B) and DHA (C) as a result of increased ALA intake. Individual data are taken from references [32, 97, 121, 124, 130-132, $146,169]$. Linear regressions were forced to go through zero. Equations describing the linear regression are: a) $y=9.24 x ; b) y=3.74 x ; c) y=0.26 x$.

Figure 5. Change in plasma phospholipid EPA (A) and RBC phospholipid EPA (B) concentration after 6 weeks intervention with either ALA or SDA or EPA. Data are calculated from James et al. [97] 
Table 1. Reported mean daily intakes of alpha-linolenic acid (ALA) and linoleic acid (LA) in different countries for men and women [29, 43, 44].

\begin{tabular}{|c|c|c|c|c|c|c|}
\hline \multirow[t]{2}{*}{ Country } & \multicolumn{2}{|c|}{$\begin{array}{l}\text { Alpha-linolenic acid } \\
\text { (ALA) g/d }\end{array}$} & \multicolumn{2}{|c|}{$\begin{array}{l}\text { Linoleic acid (LA) } \\
\mathrm{g} / \mathrm{d}\end{array}$} & \multicolumn{2}{|c|}{ LA:ALA ratio } \\
\hline & Men & Women & Men & Women & Men & Women \\
\hline $\begin{array}{l}\text { Australia/Ne } \\
\text { w Zealand }\end{array}$ & 1.4 & 0.9 & 12.8 & 9.1 & 9.1 & 10.1 \\
\hline Austria & 1.5 & 1.3 & 13.6 & 12.4 & 9.1 & 9.5 \\
\hline Belgium & 1.7 & 1.4 & 16.6 & 12.8 & 9.8 & 9.1 \\
\hline Denmark & 2.2 & 2.1 & 14.3 & 10.9 & 6.5 & 5.2 \\
\hline Finland & 1.8 & 1.3 & 8.1 & 5.8 & 4.5 & 4.5 \\
\hline France & 0.9 & 0.7 & 8.3 & 6.3 & 9.2 & 9 \\
\hline Germany & 1.59 & 1.32 & 9.3 & 8.0 & 5.8 & 6.1 \\
\hline Greece & 0.6 & 0.7 & 9.3 & 9.9 & 15.5 & 14.1 \\
\hline Iceland & 2.5 & 1.4 & NA & NA & NA & NA \\
\hline Italy & \multicolumn{2}{|l|}{$0.8^{*}$} & \multicolumn{2}{|c|}{$14.5^{*}$} & \multicolumn{2}{|c|}{$18.1^{*}$} \\
\hline Netherlands & 1.95 & 1.26 & 17.8 & 12.0 & 9.1 & 9.5 \\
\hline Norway & 1.6 & 1.0 & 12.2 & 7.8 & 7.6 & 7.8 \\
\hline Portugal & \multicolumn{2}{|l|}{$0.7^{*}$} & \multicolumn{2}{|c|}{$12.1^{*}$} & \multicolumn{2}{|c|}{$17.3^{*}$} \\
\hline Spain & \multicolumn{2}{|l|}{$0.8^{*}$} & \multicolumn{2}{|c|}{$21.6^{*}$} & \multicolumn{2}{|l|}{$27 *$} \\
\hline Sweden & 1.6 & 1.2 & 9.7 & 7.8 & 6.1 & 6.5 \\
\hline UK & \multicolumn{2}{|l|}{$1.4^{*}$} & \multicolumn{2}{|c|}{$11.4^{*}$} & \multicolumn{2}{|l|}{$8.1^{*}$} \\
\hline USA & 1.7 & 1.3 & 16.8 & 14 & 9.9 & 10.8 \\
\hline
\end{tabular}

LA:ALA ratios are based on reported mean intakes. ${ }^{*}$ Data for men and women combined. 
Table 2. Typical fatty acid compositions of common vegetable derived food oils.

\begin{tabular}{|l|l|l|l|l|l|l|l|l|l|l|l|l|l|}
\hline $\begin{array}{l}\text { Fatty } \\
\text { acid }\end{array}$ & $\begin{array}{l}\text { Olive } \\
\text { oil }\end{array}$ & $\begin{array}{l}\text { Corn } \\
\text { Oil }\end{array}$ & $\begin{array}{l}\text { Sunflower } \\
\text { oil }\end{array}$ & $\begin{array}{l}\text { Safflower } \\
\text { oil }\end{array}$ & $\begin{array}{l}\text { Soybean } \\
\text { oil }\end{array}$ & $\begin{array}{l}\text { GM- } \\
\text { soybean } \\
\text { oil }\end{array}$ & $\begin{array}{l}\text { Borage } \\
\text { oil }\end{array}$ & $\begin{array}{l}\text { Echium } \\
\text { oil }\end{array}$ & $\begin{array}{l}\text { Corn } \\
\text { Gromwell } \\
\text { oil }\end{array}$ & $\begin{array}{l}\text { Flaxseed } \\
\text { oil }\end{array}$ & $\begin{array}{l}\text { Rapeseed } \\
\text { oil }\end{array}$ \\
\hline $\begin{array}{l}16: 0 \\
\text { (palmitic) }\end{array}$ & 13 & 11 & 7 & 7 & $7-12$ & $9-13$ & 11.5 & $<1$ & 11.4 & 9 & 4 \\
\hline $\begin{array}{l}18: 0 \\
\text { (stearic) }\end{array}$ & 3 & 2 & 5 & 2 & $2-5.5$ & $2-5.5$ & 4.9 & 3.7 & 8.3 & 9 & 2 \\
\hline $\begin{array}{l}18.1 \omega-9 \\
\text { (oleic) }\end{array}$ & 71 & 28 & 19 & 13 & $19-30$ & $10-20$ & 19.5 & 15.9 & 27.1 & 18 & 62 \\
\hline $\begin{array}{l}18: 2 \omega-6 \\
\text { (LA) }\end{array}$ & 10 & 58 & 68 & 78 & $48-65$ & $15-30$ & 40.3 & 18.8 & 46.0 & 16 & 22 \\
\hline $\begin{array}{l}18: 3 \omega-3 \\
\text { (ALA) }\end{array}$ & 1 & 1 & $<1$ & $<1$ & $5-10$ & $9-12$ & $<1$ & 28.4 & 7.3 & 57 & 10 \\
\hline $\begin{array}{l}18: 3 \omega-6 \\
\text { (GLA) }\end{array}$ & NA & NA & NA & NA & NA & $5-8$ & 22.1 & 11.0 & NA & NA & NA \\
\hline $\begin{array}{l}18: 4 \omega-3 \\
\text { (SDA) }\end{array}$ & NA & NA & NA & NA & NA & $15-30$ & $<1$ & 12.5 & NA & NA & NA \\
\hline
\end{tabular}

NA, not available, but likely to be very low if present at all. Data taken from [45-48] 
Table 3. Estimated alpha-linolenic acid content of adipose tissue in men and women.

\begin{tabular}{|l|l|l|}
\hline & Men & Women \\
\hline Average body weight (kg) & 80 & 60 \\
\hline Average body fat $(\%$ of body weight) & 15 & 23 \\
\hline Total body fat $(\mathrm{kg})$ & 12 & 13.8 \\
\hline Adipose tissue TAG* $(\mathrm{kg})$ & 10.2 & 11.7 \\
\hline Adipose tissue stored fatty acid** $(\mathrm{kg})$ & 9.7 & 11.2 \\
\hline Adipose tissue ALA*** $(\mathrm{g})$ & 97 & 112 \\
\hline
\end{tabular}

*Based upon $85 \%$ of adipose tissue being TAG; **based upon $95 \%$ of TAG being fatty acid; ***based upon ALA contributing $1 \%$ of adipose tissue TAG fatty acids 
Table 4. Association studies of polymorphisms in Fads and Elovl genes and fatty acid outcomes

\begin{tabular}{|c|c|c|c|c|}
\hline Cohort & SNP & Main findings & Outcome & Reference \\
\hline European adults & $\begin{array}{l}\text { Fads1 } \\
\text { rs174544, rs174544, rs174546, } \\
\text { rs174546, rs174556, rs174561. } \\
\text { Intergenic FADS } 1 \text { - } 2 \text { rs174568, } \\
\text { rs3834458, rs968567 } \\
\text { Fads2 } \\
\text { rs99780, rs174570, rs } 2072114, \\
\text { rs174583, rs174589, rs174602, } \\
\text { rs174620, rs482548 }\end{array}$ & $\begin{array}{l}\text { Haplotype explained up to } 28 \% \text { of the variation } \\
\text { in the proportion of } 20: 4 n-6 \text {, up to } 7 \% \text { of the } \\
\text { variation in } 20: 5 n-3 \text { and up to } 3 \% \text { of the } \\
\text { variation in } 22: 6 n-3\end{array}$ & $\begin{array}{l}\text { Proportions of } \\
\text { fatty acids in } \\
\text { blood serum }\end{array}$ & $\begin{array}{l}\text { Schaeffer et } \\
\text { al. (2006)[74] }\end{array}$ \\
\hline $\begin{array}{l}\text { Patients with } \\
\text { cardiovascular } \\
\text { disease }\end{array}$ & $\begin{array}{l}\text { Fads1 } \\
\text { rs174545, rs174556, rs174561 } \\
\text { Intergenic FADS } 1-2 \\
\text { rs3834458 } \\
\text { Fads2 } \\
\text { rs174570, rs2524299, rs174583, } \\
\text { rs174589, rs498793, rs174611 } \\
\text { Intergenic FADS 2-3 } \\
\text { rs17831757, rs174627 } \\
\text { Fads3 } \\
\text { rs1000778 }\end{array}$ & $\begin{array}{l}\text { All minor alleles except for rs } 498793 \text { and } \\
\text { rs } 17831757 \text { were associated with higher } \\
\text { proportions of essential fatty acids in } \\
\text { erythrocytes compared to the major allele. The } \\
\text { minor allele of rs } 498793 \text { was associated with } \\
\text { higher proportions of } 20: 4 n-6 \text { and } 20: 5 n-3 \text {. All } \\
\text { other minor alleles were associated with lower } \\
\text { proportions of these fatty acids compared to } \\
\text { the major allele. There were variable } \\
\text { associations between the minor allele and the } \\
\text { proportion of } 22: 6 n-3 \text {. }\end{array}$ & $\begin{array}{l}\text { Proportions of } \\
\text { fatty acids in } \\
\text { erythrocytes }\end{array}$ & $\begin{array}{l}\text { Malerba et } \\
\text { al. (2008)[86] }\end{array}$ \\
\hline $\begin{array}{l}\text { Pregnant and } \\
\text { lactating } \\
\text { women }\end{array}$ & $\begin{array}{l}\text { Fads1 and } 2 \text { cluster } \\
\text { rs174553, rs174561, rs174583, } \\
\text { rs99780, rs498793, rs174575 }\end{array}$ & $\begin{array}{l}\text { Women homozygous for the minor alleles of } \\
\text { rs } 174553 \text {, rs } 99780 \text { and rs } 174583 \text { had lower } \\
20: 4 n-6 \text { and higher } 18: 2 n-6 \text { in plasma and } \\
\text { erythrocyte phospholipids }\end{array}$ & $\begin{array}{l}\text { Proportions of } \\
\text { fatty acids in } \\
\text { plasma } \\
\text { phospholipids, }\end{array}$ & $\begin{array}{l}\text { Xie et al. } \\
(2008)[87]\end{array}$ \\
\hline
\end{tabular}




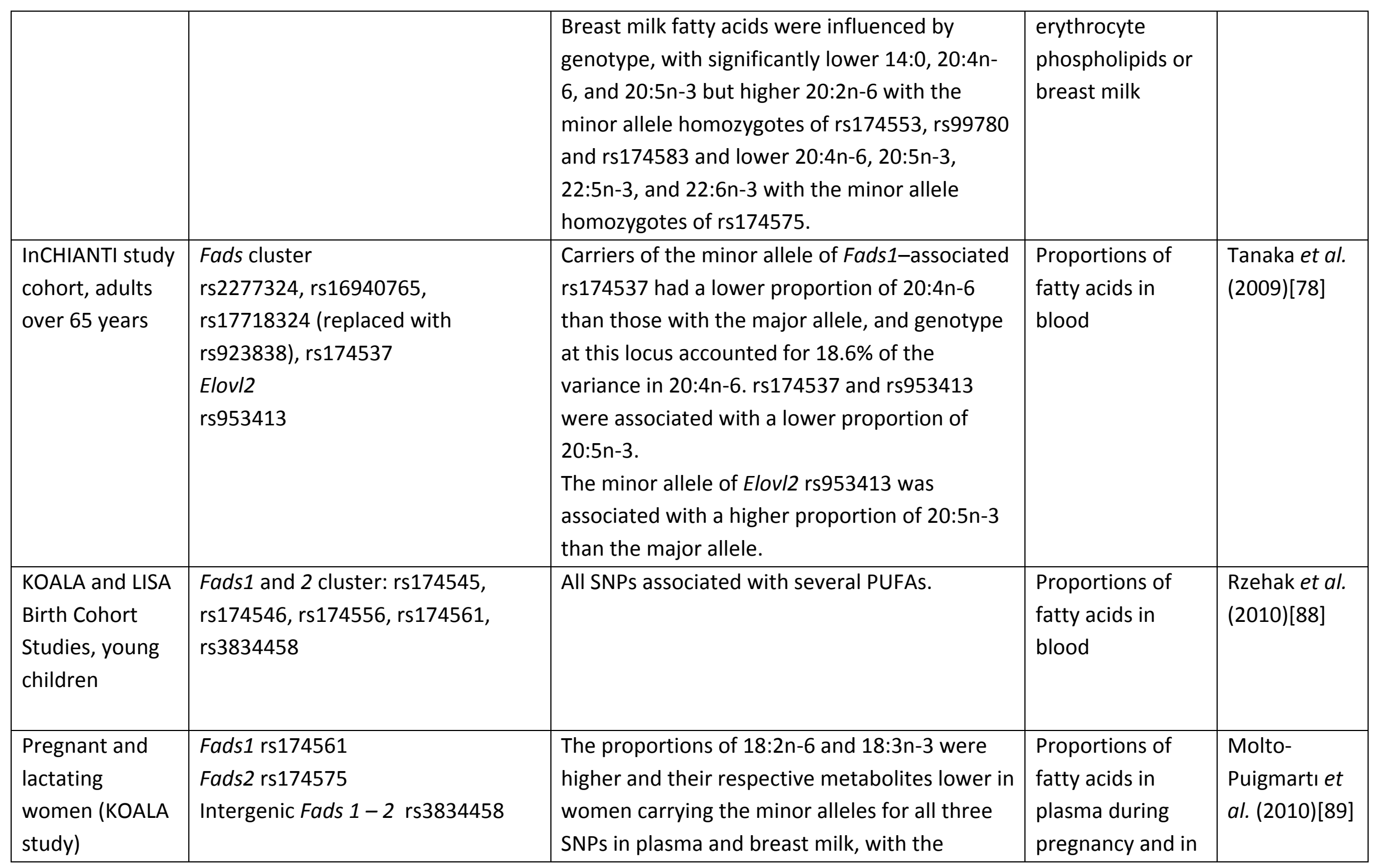




\begin{tabular}{|c|c|c|c|c|}
\hline & & $\begin{array}{l}\text { exception of } 18: 3 n-6 \text { and } 20: 4 n-6 \text { in breast milk } \\
\text { which did not vary with genotype. }\end{array}$ & breast milk & \\
\hline $\begin{array}{l}\text { Lactating } \\
\text { women in the } \\
\text { Ulm Birth } \\
\text { Cohort study }\end{array}$ & $\begin{array}{l}\text { Fads1 } \\
\text { rs174547, rs174556, } \\
\text { Fads2 } \\
\text { rs174602, rs498793, rs526126 } \\
\text { Intergenic Fads2 - } 3 \\
\text { rs174626 } \\
\text { Fads3 rs1000778, } \\
\text { rs174455 }\end{array}$ & $\begin{array}{l}\text { Significant associations of genotype with } 20: 4 n- \\
6 \text { at } 1.5 \text { and } 6 \text { months breast feeding, but not } \\
\text { with change over time. }\end{array}$ & $\begin{array}{l}\text { Fatty acid } \\
\text { concentrations in } \\
\text { breast milk }\end{array}$ & $\begin{array}{l}\text { Lattka et al. } \\
\text { (2011)[90] }\end{array}$ \\
\hline $\begin{array}{l}\text { Lactating } \\
\text { women }\end{array}$ & $\begin{array}{l}\text { Fads Cluster } \\
\text { rs174537, rs412334, rs968567, } \\
\text { rs174570, rs174575, rs2072114, } \\
\text { rs2851682, rs174602, rs526126, } \\
\text { rs174626, rs174627, rs472031 } \\
\text { rs422249, rs7482316, rs174455, } \\
\text { rs174464, rs528285, rs174468, } \\
\text { rs13966 } \\
\text { Elovl2 } \\
\text { rs3734397, rs953413, rs10498676, } \\
\text { rs6936315, rs3798719, rs7744440, } \\
\text { rs13204015 } \\
\text { Elov15 } \\
\text { rs17544159, rs2281274, rs2294859, } \\
\text { rs761179, rs9395855, rs209494, } \\
\text { rs11968589, rs209505, rs2397142, }\end{array}$ & $\begin{array}{l}\text { Minor alleles of rs174537, rs174570, } \\
\text { rs2072114, rs174602, rs526126, rs174626, } \\
\text { rs174464, rs174468 in the Fads cluster were } \\
\text { associated with lower proportion of 20:4n-6 } \\
\text { and rs174602, and } 174464 \text { were associated } \\
\text { with lower 22:6n-3. The minor alleles of } \\
\text { rs953413 and rs3798719 in Elov/2 were } \\
\text { associated with higher 20:5n-3. None of the } \\
\text { SNPs in Elov/5 were associated with the } \\
\text { proportions of any n- } 6 \text { or n-3 PUFA. }\end{array}$ & $\begin{array}{l}\text { Proportions of } \\
\text { fatty acids in } \\
\text { colostrum }\end{array}$ & $\begin{array}{l}\text { Morales et al. } \\
(2011)[91]\end{array}$ \\
\hline
\end{tabular}




\begin{tabular}{|c|c|c|c|c|}
\hline & rs12207094 & & & \\
\hline Japanese adults & 41 SNPs in the Fads cluster & $\begin{array}{l}\text { rs2845573, rs2727270, rs2727271, rs2524299, } \\
\text { rs2072114, rs2851682 in Fads2 intron } \\
\text { associated with higher Fads1 expression. } \\
\text { A 10-SNP haplotype in Fads2 was associated } \\
\text { with lower Fads1 expression. Treatment with } \\
\text { SRBP-1C or LXR agonists induced greater } \\
\text { expression of Fads1 and Fads2 in lymphocytes } \\
\text { carrying the minor alleles than those with the } \\
\text { major alleles. Polymorphic insertion-deletion } \\
\text { mutations were identified downstream of a } \\
\text { putative SRBP response element. }\end{array}$ & $\begin{array}{l}\text { Fads } 1 \text { and } 2 \\
\text { expression }\end{array}$ & $\begin{array}{l}\text { Reardon et } \\
\text { al. }(2012)[76]\end{array}$ \\
\hline $\begin{array}{l}\text { Healthy men } \\
\text { and women }\end{array}$ & $\begin{array}{l}\text { Fads1 } \\
\text { rs174537, rs174561 } \\
\text { Fads2 } \\
\text { rs3834458 }\end{array}$ & $\begin{array}{l}\text { Minor allele haplotype was associated with } \\
\text { higher proportions of } 18: 2 n-6(2-3 \%) \text { and } 18: 3 n- \\
3(5-9 \%) \text {, but lower proportions of } 20: 4 n-6 \\
(18 \%) .20: 5 n-3(13-16 \%) \text { and } 22: 6 n-3(6-10 \%) \text {. }\end{array}$ & $\begin{array}{l}\text { Proportions of } \\
\text { fatty acids in } \\
\text { plasma and } \\
\text { erythrocyte } \\
\text { phospholipids }\end{array}$ & $\begin{array}{l}\text { Al-Hilal et al. } \\
(2013)[92]\end{array}$ \\
\hline $\begin{array}{l}\text { Caucasian and } \\
\text { East Asian } \\
\text { adults }\end{array}$ & $\begin{array}{l}\text { Fads1 } \\
\text { rs174547, rs412334, rs695867, } \\
\text { rs740006 } \\
\text { Fads2 } \\
\text { rs174570, rs174576, rs174579, } \\
\text { rs174593, rs174602, rs174611, } \\
\text { rs174626, rs174627, rs17831757, } \\
\text { rs2072114, rs2845573, rs2851682, } \\
\text { rs482548, rs498793, rs526126, }\end{array}$ & $\begin{array}{l}\text { Caucasians: Men, negative associations } \\
\text { between n-6 ADI and minor alleles of } \\
\text { Fads1 rs174547 and Fads2 rs174576, and } \\
\text { rs174611. Women, negative associations } \\
\text { between the minor alleles of Fads1 rs174547 } \\
\text { and Fads2 rs174570, rs174576, rs174679, } \\
\text { rs174611, rs174593, rs174626 rs2072114, } \\
\text { rs } 2845573 \text { and rs } 2851682 \text { and n-6 ADI. } \\
\text { In East Asian women, the minor alleles of }\end{array}$ & $\begin{array}{l}\text { Aggregate } \\
\text { desaturase index } \\
\text { (ADI: 20:4n- } \\
6 / 18: 2 n-6 ; 20: 5 n- \\
3 / 18: 3 n-3 \text { ) in } \\
\text { plasma. }\end{array}$ & $\begin{array}{l}\text { Abdelmagid } \\
\text { et al. } \\
(2015)[93]\end{array}$ \\
\hline
\end{tabular}




\begin{tabular}{|l|l|l|l|}
\hline rs968567 & $\begin{array}{l}\text { Fads2 rs174602, rs174626, rs2072114, } \\
\text { rs2845573, and rs2851682 were negatively } \\
\text { associated with n-6 ADI. }\end{array}$ & \\
\hline
\end{tabular}


Table 5. Estimated conversion of alpha-linolenic acid to $\omega-3$ long-chain polyunsaturated fatty acids

\begin{tabular}{|c|c|c|c|c|c|c|c|}
\hline \multirow[t]{2}{*}{ Subjects } & \multirow[t]{2}{*}{$\begin{array}{l}\text { Form in } \\
\text { which } \alpha- \\
\text { linolenic } \\
\text { acid } \\
\text { provided }\end{array}$} & \multirow[t]{2}{*}{ Dose } & \multicolumn{4}{|l|}{ Outcomes } & \multirow[t]{2}{*}{ Reference } \\
\hline & & & & EPA & DPA & DHA & \\
\hline Adult M & $\begin{array}{l}{ }^{2} \mathrm{H} \text {-labelled } \\
\text { mixed TAG }\end{array}$ & $3.5 \mathrm{~g}$ & $\begin{array}{l}\text { Absolute and relative } \\
\text { AUC concentrations in } \\
\text { total plasma lipids }\end{array}$ & $\begin{array}{l}50 \mu \mathrm{g} / \mathrm{ml} \\
(8 \%)\end{array}$ & $\begin{array}{l}26 \mu \mathrm{g} / \mathrm{ml} \\
(4 \%)\end{array}$ & $\begin{array}{l}25 \mu \mathrm{g} / \mathrm{ml} \\
(4 \%)\end{array}$ & Emken et al. (1999)[108] \\
\hline Adults* & $\begin{array}{l}{ }^{2} \mathrm{H} \text {-labelled } \\
\text { mixed ethyl } \\
\text { ester }\end{array}$ & $1 \mathrm{~g}$ & $\begin{array}{l}\text { Concentrations in total } \\
\text { plasma lipids }\end{array}$ & $57 \mathrm{ng} / \mathrm{ml}$ & ND & $<2 \mathrm{ng} / \mathrm{ml}$ & Salem et al. (1999)[109] \\
\hline Adult $\mathrm{M}+\mathrm{F}$ & $\begin{array}{l}{\left[\mathrm{U}^{13} \mathrm{C}\right] \text { methy }} \\
\text { l ester }\end{array}$ & $45 \mathrm{mg}$ & $\begin{array}{l}\text { Peak amount in total } \\
\text { plasma lipids adjusted } \\
\text { for estimated total } \\
\text { blood volume }\end{array}$ & $120 \mu \mathrm{g}$ & $50 \mu \mathrm{g}$ & $\sim 10 \mu \mathrm{g}$ & Vermunt et al. (2000)[57] \\
\hline Adult $\mathrm{M}+\mathrm{F}$ & $\begin{array}{l}{ }^{2} \mathrm{H} \text {-labelled } \\
\text { mixed ethyl } \\
\text { ester }\end{array}$ & $1 \mathrm{~g}$ & $\begin{array}{l}\text { Mathematical modelling } \\
\text { of kinetic parameters } \\
\text { following consumption } \\
\text { of beef based diet: data } \\
\text { expressed as conversion } \\
\text { efficiency from ALA } \\
\text { using total plasma lipids }\end{array}$ & $0.2 \%$ & $0.13 \%$ & $0.05 \%$ & Pawlosky et al. (2001)[110] \\
\hline Adult M & $\begin{array}{l}{\left[\mathrm{U}-{ }^{13} \mathrm{C}\right] \text { free }} \\
\text { FA }\end{array}$ & $0.7 \mathrm{~g}$ & $\begin{array}{l}\text { Concentrations in } \\
\text { plasma TAG, NEFA, CE }\end{array}$ & $8 \%$ & $8 \%$ & ND & Burdge et al. (2002)[30] \\
\hline
\end{tabular}




\begin{tabular}{|c|c|c|c|c|c|c|c|}
\hline & & & $\begin{array}{l}\text { and PC over } 21 \mathrm{~d} \text {. } \\
\text { Fractional conversion } \\
\text { estimated from time } \mathrm{x} \\
\text { concentration AUC }\end{array}$ & & & & \\
\hline Adult $F$ & $\begin{array}{l}{\left[\mathrm{U}-{ }^{13} \mathrm{C}\right] \text { free }} \\
\text { FA }\end{array}$ & $0.7 \mathrm{~g}$ & $\begin{array}{l}\text { Concentrations in } \\
\text { plasma TAG, NEFA, CE } \\
\text { and PC over } 21 \mathrm{~d} \text {. } \\
\text { Fractional conversion } \\
\text { estimated from time } x \\
\text { concentration AUC }\end{array}$ & $21 \%$ & $6 \%$ & $9 \%$ & Burdge \& Wootton (2002)[31] \\
\hline Adult M & $\begin{array}{l}{\left[\mathrm{U}^{13} \mathrm{C}\right] \text { free }} \\
\text { FA }\end{array}$ & & $\begin{array}{l}\text { Consumption of } 17 \mathrm{~g} \\
\text { ALA/d and/or LA/d for } \\
12 \text { weeks followed by } \\
\text { tracer study and } \\
\text { measurement in total } \\
\text { plasma lipids } \\
\text {-High ALA diet } \\
\text {-High LA diet } \\
\text { - High ALA and High LA } \\
\text { diet }\end{array}$ & $\begin{array}{l}0.29 \% \\
0.19 \% \\
0.26 \%\end{array}$ & $\begin{array}{l}0.05 \% \\
0.02 \% \\
0.04 \%\end{array}$ & $\begin{array}{l}<0.01 \% \\
<0.01 \% \\
<0.01 \%\end{array}$ & Hussein et al. (2005)[111] \\
\hline Adults* & $\begin{array}{l}{\left[\mathrm{U}^{13} \mathrm{C}\right] \text { free }} \\
\text { FA }\end{array}$ & $\begin{array}{l}30 \mathrm{mg} \\
\text { bolus }+8 \\
\text { x } 20 \mathrm{mg} \\
\text { daily } \\
\text { doses }\end{array}$ & $\begin{array}{l}\text { Kinetic model, } 7 \% \text { of } \\
\text { ingested ALA was } \\
\text { incorporated into } \\
\text { plasma PL } 99.8 \% \text { of this } \\
\text { was converted to EPA } \\
\text { and } 1 \% \text { each to DPA and }\end{array}$ & $6.98 \%$ & $0.07 \%$ & $0.07 \%$ & Goyens et al. (2005)[112] \\
\hline
\end{tabular}




\begin{tabular}{|l|l|l|l|l|l|}
\hline & & DHA & & \\
\hline
\end{tabular}
CE cholesteryl ester; PL, phospholipid. *Sex not disclosed 
Table 6. Studies investigating the effect of increased alpha-linolenic acid consumption on the fatty acid composition of blood lipids in adult human subjects.

\begin{tabular}{|c|c|c|c|c|c|c|c|c|}
\hline \multirow[t]{2}{*}{ Subjects } & \multirow[t]{2}{*}{$\begin{array}{l}\text { ALA intake } \\
\text { (g/d) }\end{array}$} & \multirow[t]{2}{*}{ ALA form } & \multirow[t]{2}{*}{$\begin{array}{l}\text { Duration } \\
\text { (Weeks) }\end{array}$} & \multirow[t]{2}{*}{$\begin{array}{l}\text { Blood lipid } \\
\text { fraction }\end{array}$} & \multicolumn{3}{|c|}{$\begin{array}{l}\text { Change in proportion of total fatty } \\
\text { acids from baseline (\%) }\end{array}$} & \multirow[t]{2}{*}{ Reference } \\
\hline & & & & & EPA & DPA & DHA & \\
\hline$M+F$ & 7.8 & Flaxseed oil capsules & 2 & Plasma PC & 108 & NA & -14 & $\begin{array}{l}\text { Sanders and } \\
\text { Younger } \\
(1981)[131]\end{array}$ \\
\hline M & 14 & Flaxseed oil capsules & 6 & Plasma PL & 100 & NA & NA & $\begin{array}{l}\text { Chan et al. } \\
\text { (1993)[169] }\end{array}$ \\
\hline$M$ & $20^{*}$ & Flaxseed oil & 8 & $\begin{array}{l}\text { Total } \\
\text { serum }\end{array}$ & 0 & 20 & 38 & $\begin{array}{l}\text { Kelley et al. } \\
(1993)[128]\end{array}$ \\
\hline$M$ & 13.7 & Flaxseed oil + spread & 4 & $\begin{array}{l}\text { Plasma PL } \\
\text { Plasma CE } \\
\text { Plasma } \\
\text { TAG }\end{array}$ & $\begin{array}{l}140 \\
150 \\
200\end{array}$ & $\begin{array}{l}\text { NA } \\
\text { NA } \\
\text { NA }\end{array}$ & $\begin{array}{l}14 \\
17 \\
20\end{array}$ & $\begin{array}{l}\text { Mantzioris et } \\
\text { al. (1994)[130] }\end{array}$ \\
\hline$M$ & 5.6 & Flaxseed oil & 6 & Plasma CE & -27 & NA & NA & $\begin{array}{l}\text { Freese et al. } \\
(1994)[126]\end{array}$ \\
\hline$M+F$ & 9 & $\begin{array}{l}\text { Muffins incorporating } \\
\text { flaxseeds }\end{array}$ & 4 & $\begin{array}{l}\text { Plasma PL } \\
\text { Plasma } \\
\text { TAG }\end{array}$ & $\begin{array}{l}33 \\
300\end{array}$ & $\begin{array}{l}36 \\
250\end{array}$ & $\begin{array}{l}0 \\
-33\end{array}$ & $\begin{array}{l}\text { Cunnane et al. } \\
(1995)[121]\end{array}$ \\
\hline$M$ & 3.7 & $\begin{array}{l}\text { Flaxseed oil + spread } \\
\text { Flaxseed oil + spread }\end{array}$ & 4 & $\begin{array}{l}\text { Plasma PL } \\
\text { Plasma } \\
\text { TAG } \\
\text { Plasma PL } \\
\text { Plasma }\end{array}$ & $\begin{array}{l}80 \\
50 \\
367 \\
300\end{array}$ & $\begin{array}{l}30 \\
25 \\
50 \\
50\end{array}$ & $\begin{array}{l}11 \\
0 \\
-5 \\
0\end{array}$ & $\begin{array}{l}\text { Li et al. } \\
(1999)[129]\end{array}$ \\
\hline
\end{tabular}




\begin{tabular}{|c|c|c|c|c|c|c|c|c|}
\hline & & & & TAG & & & & \\
\hline$M+F$ & 3 & Perilla oil & 42 & $\begin{array}{l}\text { Total } \\
\text { serum }\end{array}$ & 45 & NA & 21 & $\begin{array}{l}\text { Ezaki et al. } \\
(1999)[123]\end{array}$ \\
\hline $\mathrm{M}+\mathrm{F}$ & 6.3 & Spread & 52 & Serum CE & 40 & NA & 50 & $\begin{array}{l}\text { Bemelmans et } \\
\text { al. (2002)[119] }\end{array}$ \\
\hline$F$ & 10 & Flaxseed oil capsules & 4 & $\begin{array}{l}\text { Total } \\
\text { plasma }\end{array}$ & 129 & 60 & -8 & $\begin{array}{l}\text { Francois et al. } \\
(2003)[125]\end{array}$ \\
\hline$M$ & 4.7 & Flaxseed oil capsules & 12 & Plasma PL & 60 & NA & 3 & $\begin{array}{l}\text { Wallace et al. } \\
(2003)[132]\end{array}$ \\
\hline $\mathrm{M}+\mathrm{F}$ & $\begin{array}{l}4.5 \\
9\end{array}$ & $\begin{array}{l}\text { Spread } \\
\text { Spread }\end{array}$ & $\begin{array}{l}24 \\
24\end{array}$ & $\begin{array}{l}\text { Plasma PL } \\
\text { Plasma PL }\end{array}$ & $\begin{array}{l}90 \\
133\end{array}$ & $\begin{array}{l}5 \\
33\end{array}$ & $\begin{array}{l}-3 \\
6\end{array}$ & $\begin{array}{l}\text { Finnegan et al. } \\
(2003)[124]\end{array}$ \\
\hline$M+F$ & $\begin{array}{l}0.75 \\
1.5\end{array}$ & $\begin{array}{l}\text { ALA ethyl ester in capsules } \\
\text { ALA ethyl ester in capsules }\end{array}$ & 3 & $\begin{array}{l}\text { Plasma PL } \\
\text { Plasma PL }\end{array}$ & $\begin{array}{l}15 \\
23\end{array}$ & $\begin{array}{l}0 \\
5\end{array}$ & $\begin{array}{l}-3 \\
-7\end{array}$ & $\begin{array}{l}\text { James et al. } \\
(2003)[97]\end{array}$ \\
\hline$F$ & 2.8 & Spread & 26 & Plasma PL & -26 & NA & -22 & $\begin{array}{l}\text { De Groot et al. } \\
\text { (2004)[122] }\end{array}$ \\
\hline$M+F$ & $\begin{array}{l}17.5^{*} \\
(6.5 \% \\
\text { energy) }\end{array}$ & $\begin{array}{l}\text { Walnuts, walnut oil and } \\
\text { flaxseed oil }\end{array}$ & 6 & Serum & 160 & 25 & -7 & $\begin{array}{l}\text { Zhao et al. } \\
(2004)[134]\end{array}$ \\
\hline $\mathrm{M}+\mathrm{F}$ & 3 & Flaxseed oil capsules & 26 & $\begin{array}{l}\text { Total } \\
\text { plasma }\end{array}$ & 53 & NA & 4 & $\begin{array}{l}\text { Harper et al. } \\
(2006)[127]\end{array}$ \\
\hline$M+F$ & $\begin{array}{l}1.1 \% \\
\text { energy }\end{array}$ & Spread & 6 & Plasma PL & 10 & NA & 0 & $\begin{array}{l}\text { Goyens et al. } \\
(2006)[32]\end{array}$ \\
\hline $\mathrm{M}+\mathrm{F}$ & 19.1 & $\begin{array}{l}\text { Walnuts, walnut oil and } \\
\text { flaxseed oil }\end{array}$ & 6 & $\begin{array}{l}\text { Total } \\
\text { serum }\end{array}$ & 160 & 33 & -6 & $\begin{array}{l}\text { Zhao et al. } \\
\text { (2007)[133] }\end{array}$ \\
\hline
\end{tabular}




\begin{tabular}{|c|c|c|c|c|c|c|c|c|}
\hline $\mathrm{F}$ & 9 & $\begin{array}{l}\text { Bread and grains } \\
\text { incorporating flaxseeds }\end{array}$ & 48 & $\begin{array}{l}\text { Total } \\
\text { plasma }\end{array}$ & 51 & 39 & 27 & $\begin{array}{l}\text { Dodin et al. } \\
\text { (2008)[139] }\end{array}$ \\
\hline$M+F$ & 4 & $\begin{array}{l}\text { Baked goods } \\
\text { incorporating flaxseeds }\end{array}$ & 10 & $\begin{array}{l}\text { Total } \\
\text { plasma }\end{array}$ & 13 & 11 & -22 & $\begin{array}{l}\text { Bloedon et al. } \\
(2008)[137]\end{array}$ \\
\hline $\mathrm{M}+\mathrm{F}$ & 1 & Flaxseed oil capsules & 12 & $\begin{array}{l}\text { Total } \\
\text { plasma }\end{array}$ & 7.1 & NA & -1.2 & $\begin{array}{l}\text { Kaul et al. } \\
(2008)[143]\end{array}$ \\
\hline$M+F$ & $\begin{array}{l}4.29 \\
6.50 \\
5.74\end{array}$ & $\begin{array}{l}\text { Muffins incorporating } \\
\text { - whole flaxseeds } \\
\text { - ground flaxseeds } \\
\text { - flaxseed oil }\end{array}$ & $\begin{array}{l}36 \\
36 \\
36\end{array}$ & $\begin{array}{l}\text { Total } \\
\text { plasma }\end{array}$ & $\begin{array}{l}-11 \\
14 \\
90\end{array}$ & $\begin{array}{l}\text { NA } \\
\text { NA } \\
\text { NA }\end{array}$ & $\begin{array}{l}36 \\
4 \\
20\end{array}$ & $\begin{array}{l}\text { Austria et al. } \\
(2008)[135]\end{array}$ \\
\hline$M$ & 5.4 & Flaxseed oil & 4 & $\begin{array}{l}\text { Total } \\
\text { plasma }\end{array}$ & 46 & 20 & -6 & $\begin{array}{l}\text { Barden et al. } \\
(2009)[136]\end{array}$ \\
\hline $\begin{array}{l}\text { M+F aged } \\
18-29 y\end{array}$ & 6 & $\begin{array}{l}\text { Muffins incorporating } \\
\text { - ground flaxseeds } \\
\text { - flaxseed oil }\end{array}$ & $\begin{array}{l}4 \\
4\end{array}$ & $\begin{array}{l}\text { Total } \\
\text { plasma } \\
\text { Total } \\
\text { plasma }\end{array}$ & $\begin{array}{l}22 \\
64\end{array}$ & $\begin{array}{l}\text { NA } \\
\text { NA }\end{array}$ & $\begin{array}{l}10 \\
-3\end{array}$ & $\begin{array}{l}\text { Patenaude et } \\
\text { al. (2009)[144] }\end{array}$ \\
\hline $\begin{array}{l}\text { M+F aged } \\
45-69 \text { y }\end{array}$ & 6 & $\begin{array}{l}\text { Muffins incorporating } \\
\text { - ground flaxseeds }\end{array}$ & 4 & $\begin{array}{l}\text { Total } \\
\text { plasma }\end{array}$ & 23 & NA & 101 & $\begin{array}{l}\text { Patenaude et } \\
\text { al. (2009)[144] }\end{array}$ \\
\hline
\end{tabular}




\begin{tabular}{|c|c|c|c|c|c|c|c|c|}
\hline & & - flaxseed oil & 4 & $\begin{array}{l}\text { Total } \\
\text { plasma }\end{array}$ & -2 & NA & 9 & \\
\hline$M+F$ & 4.4 & Spread & 6 & LDL & 24 & NA & -6.8 & $\begin{array}{l}\text { Egert et al. } \\
(2009)[140]\end{array}$ \\
\hline $\mathrm{F}$ & 1.2 & Flaxseed oil & 12 & $\begin{array}{l}\text { Total } \\
\text { plasma }\end{array}$ & 14 & -5 & -9 & $\begin{array}{l}\text { De Spirt et al. } \\
\text { (2009)[269] }\end{array}$ \\
\hline$M+F$ & 15.3 & $\begin{array}{l}\text { Walnuts, walnut oil and } \\
\text { flaxseed oil }\end{array}$ & 6 & $\begin{array}{l}\text { Total } \\
\text { plasma }\end{array}$ & 50 & 17 & 6 & $\begin{array}{l}\text { West et al. } \\
(2010)[149]\end{array}$ \\
\hline$M+F$ & 7.4 & $\begin{array}{l}\text { Baked goods } \\
\text { incorporating } \\
\text { - milled flaxseeds } \\
\text { - flaxseed oil }\end{array}$ & $\begin{array}{l}12 \\
12\end{array}$ & $\begin{array}{l}\text { Total } \\
\text { plasma } \\
\text { Total } \\
\text { plasma }\end{array}$ & $\begin{array}{l}33 \\
44\end{array}$ & $\begin{array}{l}11 \\
20\end{array}$ & $\begin{array}{l}-9 \\
-3\end{array}$ & $\begin{array}{l}\text { Taylor et al. } \\
(2010)[148]\end{array}$ \\
\hline$M+F$ & 4.7 & Walnuts & 4 & Plasma PL & 10 & 6 & 2 & $\begin{array}{l}\text { Chiang et al. } \\
(2012)[138]\end{array}$ \\
\hline$M+F$ & 2 & Spread & 160 & $\begin{array}{l}\text { Total } \\
\text { plasma }\end{array}$ & 17 & NA & 0 & $\begin{array}{l}\text { Geleijnse et al. } \\
\text { (2012)[141] }\end{array}$ \\
\hline$M+F$ & $\begin{array}{l}2.9 \\
5.8\end{array}$ & $\begin{array}{l}\text { Flaxseeds } \\
\text { Flaxseeds }\end{array}$ & $\begin{array}{l}12 \\
12\end{array}$ & $\begin{array}{l}\text { Total } \\
\text { serum } \\
\text { Total } \\
\text { serum }\end{array}$ & $\begin{array}{l}25 \\
20\end{array}$ & $\begin{array}{l}\text { NA } \\
\text { NA }\end{array}$ & $\begin{array}{l}0 \\
-9\end{array}$ & $\begin{array}{l}\text { Hutchins et al. } \\
\text { (2013)[142] }\end{array}$ \\
\hline$M+F$ & 0.5 & Cheese enriched with ALA & 3 & $\begin{array}{l}\text { Total } \\
\text { plasma }\end{array}$ & 36 & NA & 11 & $\begin{array}{l}\text { Pintus et al. } \\
(2013)[145]\end{array}$ \\
\hline$M+F$ & 7 & Baked goods & 24 & Total & 43 & NA & 5 & Rodriguez et \\
\hline
\end{tabular}




\begin{tabular}{|l|l|l|l|l|l|l|l|l|}
\hline & & incorporating flaxseeds & & plasma & & & al. (2013)[147] \\
\hline $\mathrm{M}+\mathrm{F}$ & 7 & Flaxseed oil & 10 & $\begin{array}{l}\text { Total } \\
\text { plasma }\end{array}$ & 31 & 14 & -7.5 & $\begin{array}{l}\text { Dittrich et al. } \\
(2014)[106]\end{array}$ \\
\hline $\mathrm{M}+\mathrm{F}$ & 3 & $\begin{array}{l}\text { Sesame/pumpkin/flaxseed } \\
\text { mix }\end{array}$ & 12 & Serum PL & 22 & 11 & 9 & $\begin{array}{l}\text { Ristic-Medic et } \\
\text { al. (2014)[146] }\end{array}$ \\
\hline
\end{tabular}

DPA, docosapentaenoic acid; M, male; F, female; PC, phosphatidylcholine; NA, data not available; CE cholesteryl ester; PL, phospholipid; PE, phosphatidylethanolamine; LDL, low density lipoprotein. *Approximate intake 
Table 7. Studies investigating effect of increased alpha-linolenic acid consumption on the fatty acid composition of circulating cells in adult human subjects.

\begin{tabular}{|c|c|c|c|c|c|c|c|c|}
\hline \multirow[t]{2}{*}{ Subjects } & \multirow[t]{2}{*}{$\begin{array}{l}\text { ALA intake } \\
\text { (g/d) }\end{array}$} & \multirow[t]{2}{*}{ ALA form } & \multirow[t]{2}{*}{$\begin{array}{l}\text { Duration } \\
\text { (Weeks) }\end{array}$} & \multirow[t]{2}{*}{$\begin{array}{l}\text { Cell lipid } \\
\text { fraction }\end{array}$} & \multicolumn{3}{|c|}{$\begin{array}{c}\text { Change in proportion of total fatty acids } \\
\text { from baseline (\%) }\end{array}$} & \multirow[t]{2}{*}{ Reference } \\
\hline & & & & & EPA & DPA & DHA & \\
\hline $\mathrm{M}+\mathrm{F}$ & 7.8 & $\begin{array}{l}\text { Flaxseed oil } \\
\text { capsules }\end{array}$ & 2 & Platelet PL & 100 & NA & -3 & $\begin{array}{l}\text { Sanders and } \\
\text { Younger } \\
(1981)[131] \\
\text { Sanders and } \\
\text { Roshanai } \\
(1983)[158]\end{array}$ \\
\hline$M$ & 8.5 & $\begin{array}{l}\text { Rapeseed oil } \\
\text { based foods }\end{array}$ & 2.5 & $\begin{array}{l}\text { Platelet PC } \\
\text { Platelet PE }\end{array}$ & $\begin{array}{l}100 \\
133\end{array}$ & $\begin{array}{l}0 \\
51\end{array}$ & $\begin{array}{l}-27 \\
-5\end{array}$ & $\begin{array}{l}\text { Weaver et al. } \\
(1990)[159]\end{array}$ \\
\hline$M$ & $\begin{array}{l}8 \% \text { of fatty } \\
\text { acids }\end{array}$ & $\begin{array}{l}\text { Rapeseed oil } \\
\text { based foods }\end{array}$ & 8 & Platelet PL & 17 & 24 & 20 & $\begin{array}{l}\text { Kwon et al. } \\
(1991)[155]\end{array}$ \\
\hline$M$ & $\begin{array}{l}2.1 \% \text { of } \\
\text { energy }\end{array}$ & $\begin{array}{l}\text { Rapeseed oil } \\
\text { based foods }\end{array}$ & 3 & $\begin{array}{l}\text { Total platelet } \\
\text { lipid }\end{array}$ & -8 & NA & 20 & $\begin{array}{l}\text { Mutanen et al. } \\
(1992)[156]\end{array}$ \\
\hline$M$ & $20^{*}$ & Flaxseed oil & 8 & $\begin{array}{l}\text { Total } \\
\text { mononuclear } \\
\text { cell lipid }\end{array}$ & 0 & 45 & -36 & $\begin{array}{l}\text { Kelley et al. } \\
(1993)[128]\end{array}$ \\
\hline$M$ & 13.7 & $\begin{array}{l}\text { Flaxseed oil + } \\
\text { spread }\end{array}$ & 4 & $\begin{array}{l}\text { Neutrophil } \\
\text { PL }\end{array}$ & 140 & NA & 0 & $\begin{array}{l}\text { Mantzioris et al. } \\
(1994)[130]\end{array}$ \\
\hline$M+F$ & $\begin{array}{l}18(8.5 \% \\
\text { energy) }\end{array}$ & Flaxseed oil & 3 & Platelet PL & 140 & 45 & -11 & $\begin{array}{l}\text { Allman et al. } \\
(1995)[150]\end{array}$ \\
\hline
\end{tabular}




\begin{tabular}{|c|c|c|c|c|c|c|c|c|}
\hline$M$ & 13.7 & $\begin{array}{l}\text { Flaxseed oil + } \\
\text { spread }\end{array}$ & 4 & $\begin{array}{l}\text { Mononuclear } \\
\text { cell PL }\end{array}$ & 133 & NA & -4 & $\begin{array}{l}\text { Caughey et al. } \\
(1996)[152]\end{array}$ \\
\hline$M$ & $\begin{array}{l}3.7 \\
15.4\end{array}$ & $\begin{array}{l}\text { Flaxseed oil + } \\
\text { spread } \\
\text { Flaxseed oil + } \\
\text { spread }\end{array}$ & 4 & $\begin{array}{l}\text { Platelet PL } \\
\text { Platelet PL }\end{array}$ & $\begin{array}{l}50 \\
150\end{array}$ & $\begin{array}{l}21 \\
56\end{array}$ & $\begin{array}{l}0 \\
-10\end{array}$ & $\begin{array}{l}\text { Li et al. } \\
\text { (1999)[129] }\end{array}$ \\
\hline$M$ & 3.5 & $\begin{array}{l}\text { Flaxseed oil + } \\
\text { foods }\end{array}$ & 6 & $\begin{array}{l}\text { Total platelet } \\
\text { lipid }\end{array}$ & 200 & 46 & -50 & $\begin{array}{l}\text { Allman-Farinelli } \\
\text { et al. } \\
\text { (1999)[151] }\end{array}$ \\
\hline$M$ & 4.7 & $\begin{array}{l}\text { Flaxseed oil } \\
\text { capsules }\end{array}$ & 12 & $\begin{array}{l}\text { Neutrophil } \\
\text { PL }\end{array}$ & 30 & NA & 15 & $\begin{array}{l}\text { Healy et al. } \\
(2000)[153]\end{array}$ \\
\hline$M+F$ & $\begin{array}{l}0.75 \\
1.5\end{array}$ & $\begin{array}{l}\text { ALA ethyl } \\
\text { ester in } \\
\text { capsules } \\
\text { ALA ethyl } \\
\text { ester in } \\
\text { capsules }\end{array}$ & 4 & $\begin{array}{l}\text { RBC PL } \\
\text { RBC PL }\end{array}$ & 13 & 0 & -7 & $\begin{array}{l}\text { James et al. } \\
(2003)[97]\end{array}$ \\
\hline$M+F$ & $\begin{array}{l}4.5 \\
9.5\end{array}$ & $\begin{array}{l}\text { Spread } \\
\text { Spread }\end{array}$ & $\begin{array}{l}24 \\
24 \\
\end{array}$ & $\begin{array}{l}\text { Mononuclear } \\
\text { cell PL }\end{array}$ & $\begin{array}{l}0 \\
33\end{array}$ & $\begin{array}{l}6 \\
0\end{array}$ & $\begin{array}{l}-28 \\
-20\end{array}$ & $\begin{array}{l}\text { Kew et al. } \\
(2003)[154]\end{array}$ \\
\hline$M$ & 15 & $\begin{array}{l}\text { Flaxseed oil } \\
\text { and spread }\end{array}$ & 12 & $\begin{array}{l}\text { Total RBC } \\
\text { lipid }\end{array}$ & 153 & 0 & -6 & $\begin{array}{l}\text { Wlkinson et al. } \\
(2005)[160]\end{array}$ \\
\hline$M+F$ & 11.9 & $\begin{array}{l}\text { Flaxseed oil } \\
\text { capsules }\end{array}$ & 8 & RBC PL & 1020 & NA & 41 & $\begin{array}{l}\text { Nelson et al. } \\
(2007)[157]\end{array}$ \\
\hline$M+F$ & 19.1 & $\begin{array}{l}\text { Walnuts, } \\
\text { walnut oil }\end{array}$ & 6 & $\begin{array}{l}\text { Total } \\
\text { mononuclear }\end{array}$ & 300 & 10 & 0 & $\begin{array}{l}\text { Zhao et al. } \\
(2007)[133]\end{array}$ \\
\hline
\end{tabular}




\begin{tabular}{|c|c|c|c|c|c|c|c|c|}
\hline & & $\begin{array}{l}\text { and flaxseed } \\
\text { oil }\end{array}$ & & cell lipid & & & & \\
\hline$M+F$ & 4.7 & Walnuts & 4 & $\begin{array}{l}\text { Total RBC } \\
\text { lipid }\end{array}$ & 14 & NA & -1.3 & $\begin{array}{l}\text { Rajaram et al. } \\
(2009)[164]\end{array}$ \\
\hline$M+F$ & $\begin{array}{l}2.2 \\
6.6\end{array}$ & $\begin{array}{l}\text { Flaxseed oil } \\
\text { Flaxseed oil }\end{array}$ & $\begin{array}{l}8 \\
8\end{array}$ & $\begin{array}{l}\text { Total RBC } \\
\text { lipid }\end{array}$ & $\begin{array}{l}31 \\
65\end{array}$ & $\begin{array}{l}\text { NA } \\
\text { NA }\end{array}$ & $\begin{array}{l}-8 \\
-14\end{array}$ & $\begin{array}{l}\text { Dewell et al. } \\
(2011)[161]\end{array}$ \\
\hline$M+F$ & 4.4 & Spread & 6 & $\begin{array}{l}\text { Total RBC } \\
\text { lipid }\end{array}$ & 13 & NA & -13 & $\begin{array}{l}\text { Egert et al. } \\
(2012)[162]\end{array}$ \\
\hline$M+F$ & 8.7 & $\begin{array}{l}\text { Organic } \\
\text { flaxseed oil }\end{array}$ & 6 & RBC PL & 47 & 17 & 0.6 & $\begin{array}{l}\text { Kontogianni et } \\
\text { al. (2013)[163] }\end{array}$ \\
\hline$M+F$ & 7 & Flaxseed oil & 10 & $\begin{array}{l}\text { Total RBC } \\
\text { lipid }\end{array}$ & 31 & 19 & -2 & $\begin{array}{l}\text { Dittrich et al. } \\
\text { (2014)[106] }\end{array}$ \\
\hline
\end{tabular}

DPA, docosapentaenoic acid; M, male; F, female; PC, phosphatidylcholine; RBC, red blood cell; NA, data not available; PL, phospholipid; PE, phosphatidylethanolamine. *Approximate intake 
Table 8. Studies investigating the effect of increased stearidonic acid consumption on the fatty acid composition of blood lipids and blood cells in adult human subjects.

\begin{tabular}{|c|c|c|c|c|c|c|c|c|}
\hline \multirow[t]{2}{*}{ Subjects } & \multirow[t]{2}{*}{$\begin{array}{l}\text { SDA intake } \\
\qquad(\mathrm{g} / \mathrm{d})\end{array}$} & \multirow[t]{2}{*}{ SDA form } & \multirow[t]{2}{*}{$\begin{array}{l}\text { Duration } \\
\text { (Weeks) }\end{array}$} & \multirow[t]{2}{*}{$\begin{array}{l}\text { Blood } \\
\text { fraction }\end{array}$} & \multicolumn{3}{|c|}{$\begin{array}{l}\text { Change in proportion of total fatty } \\
\text { acids from baseline (\%) }\end{array}$} & \multirow[t]{2}{*}{ Reference } \\
\hline & & & & & EPA & DPA & DHA & \\
\hline$M+F$ & $\begin{array}{l}0.75 \\
1.5 \\
\\
0.75 \\
1.5\end{array}$ & $\begin{array}{l}\text { Ethyl ester in } \\
\text { capsules }\end{array}$ & $\begin{array}{l}3 \\
3 \\
3 \\
3\end{array}$ & $\begin{array}{l}\text { Plasma } \\
\text { phospholipid } \\
\text { Total RBC } \\
\text { lipid }\end{array}$ & $\begin{array}{l}41 \\
87 \\
21 \\
50\end{array}$ & $\begin{array}{l}16 \\
28 \\
3.5 \\
9.5\end{array}$ & $\begin{array}{l}-4 \\
-4 \\
-3.5 \\
-6\end{array}$ & $\begin{array}{l}\text { James et al. } \\
\text { (2003)[97] }\end{array}$ \\
\hline$M$ & 1 & $\begin{array}{l}\text { Echium oil } \\
\text { capsules }\end{array}$ & 12 & $\begin{array}{l}\text { Total } \\
\text { mononuclear } \\
\text { cell lipid }\end{array}$ & 125 & NA & 61 & $\begin{array}{l}\text { Miles et al. } \\
(2004)[99]\end{array}$ \\
\hline$M$ & 1 & $\begin{array}{l}\text { Echium oil } \\
\text { capsules }\end{array}$ & 12 & $\begin{array}{l}\text { Plasma } \\
\text { phospholipid } \\
\text { Plasma } \\
\text { cholesteryl } \\
\text { ester } \\
\text { Plasma } \\
\text { triacylglycerol }\end{array}$ & $\begin{array}{l}33 \\
25 \\
27\end{array}$ & $\begin{array}{l}\text { NA } \\
\text { NA } \\
\text { NA }\end{array}$ & $\begin{array}{l}11.5 \\
47 \\
2\end{array}$ & $\begin{array}{l}\text { Miles et al. } \\
(2004)[167]\end{array}$ \\
\hline $\mathrm{M}+\mathrm{F}$ & 1.9 & $\begin{array}{l}\text { Echium oil } \\
\text { capsules }\end{array}$ & 4 & $\begin{array}{l}\text { Total plasma } \\
\text { Total } \\
\text { neutrophil } \\
\text { lipid }\end{array}$ & $\begin{array}{l}190 \\
400\end{array}$ & $\begin{array}{l}73 \\
100\end{array}$ & $\begin{array}{l}1 \\
29\end{array}$ & $\begin{array}{l}\text { Surette et al. } \\
(2004)[38]\end{array}$ \\
\hline
\end{tabular}




\begin{tabular}{|c|c|c|c|c|c|c|c|c|}
\hline $\mathrm{M}+\mathrm{F}$ & 3.7 & $\begin{array}{l}\text { SDA-enriched } \\
\text { soybean oil }\end{array}$ & 16 & $\begin{array}{l}\text { Total RBC } \\
\text { lipid }\end{array}$ & 188 & NA & 0 & $\begin{array}{l}\text { Harris et al. } \\
(2008)[166]\end{array}$ \\
\hline$M+F$ & 4.2 & $\begin{array}{l}\text { SDA-enriched } \\
\text { soybean oil }\end{array}$ & 12 & $\begin{array}{l}\text { Total RBC } \\
\text { lipid }\end{array}$ & 4 & 3 & 1 & $\begin{array}{l}\text { Lemke et al. } \\
(2010)[98]\end{array}$ \\
\hline$M+F$ & $\begin{array}{l}0.44 \\
1.3 \\
2.6 \\
5.2\end{array}$ & $\begin{array}{l}\text { Ethyl ester in } \\
\text { capsules }\end{array}$ & 12 & $\begin{array}{l}\text { Total RBC } \\
\text { lipid }\end{array}$ & $\begin{array}{l}11 \\
89 \\
118 \\
172\end{array}$ & $\begin{array}{l}8 \\
33 \\
40 \\
47\end{array}$ & $\begin{array}{l}-5 \\
2 \\
0.6 \\
3\end{array}$ & $\begin{array}{l}\text { Krul et al. } \\
(2011)[100]\end{array}$ \\
\hline$M+F$ & $\begin{array}{l}0.25 \\
0.5 \\
0.875 \\
1.75\end{array}$ & $\begin{array}{l}\text { Echium oil and } \\
\text { Borage oil } \\
\text { capsules }\end{array}$ & 3 & Total plasma & $\begin{array}{l}19 \\
56 \\
70 \\
200\end{array}$ & $\begin{array}{l}10 \\
20 \\
22 \\
2\end{array}$ & $\begin{array}{l}3 \\
-5 \\
0 \\
9\end{array}$ & $\begin{array}{l}\text { Arm et } \\
\text { al.(2013)[165] }\end{array}$ \\
\hline$M+F$ & 7 & $\begin{array}{l}\text { SDA-enriched } \\
\text { soybean oil in } \\
\text { foods }\end{array}$ & 12 & $\begin{array}{l}\text { Total RBC } \\
\text { lipid }\end{array}$ & 89 & 30 & -5 & $\begin{array}{l}\text { Lemke et al. } \\
(2013)[104]\end{array}$ \\
\hline $\mathrm{M}+\mathrm{F}$ & 1.2 & $\begin{array}{l}\text { Echium oil } \\
\text { capsules }\end{array}$ & 6 & $\begin{array}{l}\text { Total RBC } \\
\text { lipid }\end{array}$ & 20 & 10 & -3 & $\begin{array}{l}\text { Pieters et al. } \\
(2014)[105]\end{array}$ \\
\hline$M+F$ & 2 & $\begin{array}{l}\text { Echium oil } \\
\text { capsules }\end{array}$ & 10 & $\begin{array}{l}\text { Total plasma } \\
\text { Total RBC } \\
\text { lipid }\end{array}$ & $\begin{array}{l}115 \\
63\end{array}$ & $\begin{array}{l}66 \\
35\end{array}$ & $\begin{array}{l}-2 \\
-11\end{array}$ & $\begin{array}{l}\text { Dittrich et al. } \\
\text { (2014)[106] }\end{array}$ \\
\hline $\begin{array}{l}M+F \\
20-35 \text { y } \\
49-69 y \\
\text { MetS }\end{array}$ & 2 & $\begin{array}{l}\text { Echium oil } \\
\text { capsules }\end{array}$ & 8 & Total plasma & $\begin{array}{l}183 \\
165 \\
123\end{array}$ & $\begin{array}{l}74 \\
64 \\
53\end{array}$ & $\begin{array}{l}0 \\
-4 \\
-10\end{array}$ & $\begin{array}{l}\text { Kuhnt et al. } \\
(2014)[107]\end{array}$ \\
\hline
\end{tabular}




\begin{tabular}{|l|l|l|l|l|l|l|l|}
\hline $\begin{array}{l}20-35 \text { y } \\
\text { 49-69 y }\end{array}$ & & & Total & 74 & 40 & -23 & \\
MetS & & mononuclear & 98 & 41 & -21 \\
\\
\hline
\end{tabular}

DPA, docosapentaenoic acid; M, male; F, female; y, years; RBC, red blood cell; MetS, metabolic syndrome ; NA, data not available 
Table 9. Controlled intervention studies investigating effect of increased ALA consumption on blood lipid concentrations in adult human subjects.

\begin{tabular}{|c|c|c|c|c|c|c|}
\hline Subjects & $\begin{array}{l}\text { ALA intake } \\
\text { (g/d) }\end{array}$ & ALA form & $\begin{array}{l}\text { Duration } \\
\text { (Weeks) }\end{array}$ & Outcomes investigated & $\begin{array}{c}\text { Effect of ALA } \\
\text { (\% change where } \\
\text { significant) }\end{array}$ & Reference \\
\hline$M+F$ & 9.4 & Flaxseed oil capsules & 2 & $\begin{array}{l}\text { Total cholesterol } \\
\text { HDL-cholesterol } \\
\text { Triacylglycerol }\end{array}$ & $\begin{array}{l}\text { None } \\
\text { None } \\
\text { None }\end{array}$ & $\begin{array}{l}\text { Sanders and } \\
\text { Roshani } \\
(1983)[158]\end{array}$ \\
\hline$M+F$ & 38 & Flaxseed oil & 2 & $\begin{array}{l}\text { Total cholesterol } \\
\text { LDL-cholesterol } \\
\text { HDL-cholesterol } \\
\text { Triacylglycerol }\end{array}$ & $\begin{array}{l}\text { None } \\
\text { None } \\
\text { None } \\
-25\end{array}$ & $\begin{array}{l}\text { Singer et al. } \\
(1986)[233]\end{array}$ \\
\hline$M$ & 9.2 & $\begin{array}{l}\text { Milkshake including } \\
\text { flaxseed oil }\end{array}$ & 9 & $\begin{array}{l}\text { Total cholesterol } \\
\text { LDL-cholesterol } \\
\text { HDL-cholesterol } \\
\text { VLDL-cholesterol } \\
\text { Triacylglycerol }\end{array}$ & $\begin{array}{l}\text { None } \\
\text { None } \\
\text { None } \\
\text { None } \\
\text { None }\end{array}$ & $\begin{array}{l}\text { Kestin et al. } \\
(1990)[229]\end{array}$ \\
\hline M & $\sim 20$ & Flaxseed oil & 8 & $\begin{array}{l}\text { Total cholesterol } \\
\text { LDL-cholesterol } \\
\text { HDL-cholesterol } \\
\text { Triacylglycerol }\end{array}$ & $\begin{array}{l}\text { None } \\
\text { None } \\
\text { None } \\
\text { None }\end{array}$ & $\begin{array}{l}\text { Kelley et al. } \\
(1993)[128]\end{array}$ \\
\hline
\end{tabular}




\begin{tabular}{|c|c|c|c|c|c|c|}
\hline & & & & $\begin{array}{l}\text { Apo B } \\
\text { Apo A1 }\end{array}$ & $\begin{array}{l}\text { None } \\
\text { None }\end{array}$ & \\
\hline$M$ & 13.7 & Flaxseed oil + spread & 4 & $\begin{array}{l}\text { Total cholesterol } \\
\text { LDL-cholesterol } \\
\text { HDL-cholesterol } \\
\text { Triacylglycerol }\end{array}$ & $\begin{array}{l}\text { None } \\
\text { None } \\
+20 \\
\text { None }\end{array}$ & $\begin{array}{l}\text { Mantazoris et al. } \\
(1994)[130]\end{array}$ \\
\hline $\mathrm{M}+\mathrm{F}$ & 9 & $\begin{array}{l}\text { Muffins incorporating } \\
\text { flaxseeds }\end{array}$ & 4 & $\begin{array}{l}\text { Total cholesterol } \\
\text { LDL-cholesterol } \\
\text { HDL-cholesterol } \\
\text { Triacylglycerol }\end{array}$ & $\begin{array}{l}-6 \\
-9 \\
\text { None } \\
\text { None }\end{array}$ & $\begin{array}{l}\text { Cunnane et al. } \\
(1995)[121]\end{array}$ \\
\hline $\mathrm{M}+\mathrm{F}$ & 2.5 & Flaxseed oil capsules & 12 & $\begin{array}{l}\text { Total cholesterol } \\
\text { LDL-cholesterol } \\
\text { HDL-cholesterol } \\
\text { Triacylglycerol }\end{array}$ & $\begin{array}{l}\text { None } \\
\text { None } \\
\text { None } \\
\text { None }\end{array}$ & $\begin{array}{l}\text { Layne et al. } \\
(1996)[230]\end{array}$ \\
\hline $\mathrm{M}+\mathrm{F}$ & $20 *$ & $\begin{array}{l}\text { Spread + food made with } \\
\text { flaxseed oil }\end{array}$ & 4 & $\begin{array}{l}\text { Total cholesterol } \\
\text { LDL-cholesterol } \\
\text { HDL-cholesterol } \\
\text { Triacylglycerol }\end{array}$ & $\begin{array}{l}\text { None } \\
\text { None } \\
-8 \\
\text { None }\end{array}$ & $\begin{array}{l}\text { Nestel et al. } \\
(1997)[231]\end{array}$ \\
\hline$M$ & 10.1 & ALA rich foods & 3 and 6 & $\begin{array}{l}\text { Total cholesterol } \\
\text { LDL-cholesterol } \\
\text { HDL-cholesterol } \\
\text { Triacylglycerol }\end{array}$ & $\begin{array}{l}\text { None } \\
\text { None } \\
\text { None } \\
\text { None }\end{array}$ & $\begin{array}{l}\text { Pang et al. } \\
(1998)[232]\end{array}$ \\
\hline $\mathrm{F}$ & 8.5 & Muffins and bread & 6 & Total cholesterol & -7 & Arjmandi et al. \\
\hline
\end{tabular}




\begin{tabular}{|c|c|c|c|c|c|c|}
\hline & & $\begin{array}{l}\text { incorporating flaxseeds } \\
\text { and flaxseed oil }\end{array}$ & & $\begin{array}{l}\text { LDL-cholesterol } \\
\text { HDL-cholesterol } \\
\text { Triacylglycerol } \\
\text { Lipoprotein (a) }\end{array}$ & $\begin{array}{l}-16 \\
\text { None } \\
\text { None } \\
-6\end{array}$ & $(1998)[227]$ \\
\hline M & $\begin{array}{l}3.7 \\
15.4\end{array}$ & $\begin{array}{l}\text { Flaxseed oil + spread } \\
\text { Flaxseed oil + spread }\end{array}$ & 4 & $\begin{array}{l}\text { Total cholesterol } \\
\text { LDL-cholesterol } \\
\text { HDL-cholesterol } \\
\text { Triacylglycerol } \\
\text { Total cholesterol } \\
\text { LDL-cholesterol } \\
\text { HDL-cholesterol } \\
\text { Triacylglycerol }\end{array}$ & $\begin{array}{l}\text { None } \\
\text { None } \\
\text { None } \\
\text { None } \\
\text { None } \\
\text { None } \\
\text { None } \\
\text { None }\end{array}$ & $\begin{array}{l}\text { Li et } \\
\text { al.(1999)[129] }\end{array}$ \\
\hline$M$ & 4.2 & Perilla oil & 40 & $\begin{array}{l}\text { Total cholesterol } \\
\text { LDL-cholesterol } \\
\text { HDL-cholesterol } \\
\text { VLDL-cholesterol } \\
\text { Triacylglycerol } \\
\text { VLDL- Triacylglycerol }\end{array}$ & $\begin{array}{l}\text { None } \\
\text { None } \\
\text { None } \\
\text { None } \\
\text { None } \\
\text { None }\end{array}$ & $\begin{array}{l}\text { Ezaki et } \\
\text { al.(1999)[123] }\end{array}$ \\
\hline$M+F$ & 10 & $\begin{array}{l}\text { Spread and foods made } \\
\text { with rapeseed oil }\end{array}$ & 4 & $\begin{array}{l}\text { Total cholesterol } \\
\text { LDL-cholesterol } \\
\text { HDL-cholesterol } \\
\text { Triacylglycerol }\end{array}$ & $\begin{array}{l}-15 \\
-18 \\
-12 \\
\text { None }\end{array}$ & $\begin{array}{l}\text { Junker et al. } \\
(2001)[235]\end{array}$ \\
\hline$M+F$ & 9.2 & $\begin{array}{l}\text { Spread, rapeseed oil and } \\
\text { foods made with rapeseed } \\
\text { oil }\end{array}$ & 4 & $\begin{array}{l}\text { Total cholesterol } \\
\text { LDL-cholesterol } \\
\text { HDL-cholesterol } \\
\text { VLDL-cholesterol }\end{array}$ & $\begin{array}{l}-11 \\
-11 \\
-9 \\
\text { None }\end{array}$ & $\begin{array}{l}\text { Sodergren et al. } \\
(2001)[237]\end{array}$ \\
\hline
\end{tabular}




\begin{tabular}{|c|c|c|c|c|c|c|}
\hline & & & & $\begin{array}{l}\text { Triacylglycerol } \\
\text { Apo A1 } \\
\text { Apo B } \\
\text { Lipoprotein }\end{array}$ & $\begin{array}{l}\text { None } \\
\text { None } \\
\text { None } \\
\text { None }\end{array}$ & \\
\hline$M+F$ & 3 & Rapeseed oil & 6 & $\begin{array}{l}\text { Total cholesterol } \\
\text { LDL-cholesterol } \\
\text { HDL-cholesterol } \\
\text { Triacylglycerol }\end{array}$ & $\begin{array}{l}-6 \\
-12 \\
\text { None } \\
\text { None }\end{array}$ & $\begin{array}{l}\text { Karvonen et al. } \\
(2002)[236]\end{array}$ \\
\hline$M+F$ & 6.3 & Spread & 104 & $\begin{array}{l}\text { Total cholesterol } \\
\text { LDL-cholesterol } \\
\text { HDL-cholesterol } \\
\text { Triacylglycerol }\end{array}$ & $\begin{array}{l}-12 \\
+7 \\
+11 \\
\text { None }\end{array}$ & $\begin{array}{l}\text { Bemelmans et al. } \\
(2002)[119]\end{array}$ \\
\hline
\end{tabular}




\begin{tabular}{|c|c|c|c|c|c|c|}
\hline$M$ & 8 & Flaxseed oil & 12 & $\begin{array}{l}\text { Total cholesterol } \\
\text { LDL-cholesterol } \\
\text { HDL-cholesterol } \\
\text { Triacylglycerol }\end{array}$ & $\begin{array}{l}\text { None } \\
\text { None } \\
-4 \\
\text { None }\end{array}$ & $\begin{array}{l}\text { Rallidis et al. } \\
(2003)[240]\end{array}$ \\
\hline$M+F$ & $\begin{array}{l}17.5^{*}(6.5 \% \\
\text { energy) }\end{array}$ & $\begin{array}{l}\text { Walnuts, walnut oil and } \\
\text { flaxseed oil }\end{array}$ & 6 & $\begin{array}{l}\text { Total cholesterol } \\
\text { LDL-cholesterol } \\
\text { HDL-cholesterol } \\
\text { Triacylglycerol } \\
\text { Apo A } \\
\text { Apo B }\end{array}$ & $\begin{array}{l}-11 \\
-11 \\
-6 \\
-18 \\
-5 \\
-10\end{array}$ & $\begin{array}{l}\text { Zhao et } \\
\text { al.(2004)[134] }\end{array}$ \\
\hline M & 15 & Flaxseed oil and spread & 12 & $\begin{array}{l}\text { Total cholesterol } \\
\text { LDL-cholesterol } \\
\text { HDL-cholesterol } \\
\text { Triacylglycerol }\end{array}$ & $\begin{array}{l}-21 \\
\text { None } \\
-8 \\
-10\end{array}$ & $\begin{array}{l}\text { Wilkinson et al. } \\
(2005)[160]\end{array}$ \\
\hline$M+F$ & 5 & Flaxseed flour & 2 & $\begin{array}{l}\text { Total cholesterol } \\
\text { LDL-cholesterol } \\
\text { VLDL-cholesterol } \\
\text { HDL-cholesterol } \\
\text { Triacylglycerol }\end{array}$ & $\begin{array}{l}\text { None } \\
\text { None } \\
\text { None } \\
\text { None } \\
\text { None }\end{array}$ & $\begin{array}{l}\text { Faintuch et al. } \\
\text { (2007)[238] }\end{array}$ \\
\hline$M+F$ & 8 & Flaxseed oil & 12 & Total cholesterol & None & Paschos et al. \\
\hline
\end{tabular}




\begin{tabular}{|c|c|c|c|c|c|c|}
\hline & & & & $\begin{array}{l}\text { LDL-cholesterol } \\
\text { HDL-cholesterol } \\
\text { Triacylglycerol }\end{array}$ & $\begin{array}{l}\text { None } \\
-5 \\
\text { None }\end{array}$ & $(2007)[239]$ \\
\hline$M+F$ & 4 & $\begin{array}{l}\text { Baked goods } \\
\text { incorporating flaxseeds }\end{array}$ & 10 & $\begin{array}{l}\text { Total cholesterol } \\
\text { LDL-cholesterol } \\
\text { VLDL-cholesterol } \\
\text { HDL-cholesterol Male } \\
\text { HDL-cholesterol Female } \\
\text { Triacylglycerol } \\
\text { Apo A } \\
\text { Apo B } \\
\text { Lipoprotein (a) }\end{array}$ & $\begin{array}{l}\text { None } \\
\text { None } \\
\text { None } \\
-9 \\
\text { None } \\
\text { None } \\
\text { None } \\
\text { None } \\
-12\end{array}$ & $\begin{array}{l}\text { Bloedon et al. } \\
(2008)[137]\end{array}$ \\
\hline $\mathrm{F}$ & 9 & $\begin{array}{l}\text { Bread and grains } \\
\text { incorporating flaxseeds }\end{array}$ & 48 & $\begin{array}{l}\text { Apo A } \\
\text { Apo B } \\
\text { Lipoprotein }\end{array}$ & $\begin{array}{l}\text { None } \\
\text { None } \\
\text { None }\end{array}$ & $\begin{array}{l}\text { Dodin et al. } \\
(2008)[139]\end{array}$ \\
\hline$M$ & 5.4 & Flaxseed oil & 4 & $\begin{array}{l}\text { Total cholesterol } \\
\text { HDL-cholesterol }\end{array}$ & $\begin{array}{l}\text { None } \\
\text { None }\end{array}$ & $\begin{array}{l}\text { Barden et al. } \\
\text { (2009)[136] }\end{array}$ \\
\hline$M+F$ & 4.4 & Spread & 6 & $\begin{array}{l}\text { Total cholesterol } \\
\text { LDL-cholesterol } \\
\text { VLDL-cholesterol } \\
\text { HDL-cholesterol } \\
\text { Triacylglycerol }\end{array}$ & $\begin{array}{l}\text { None } \\
\text { None } \\
\text { None } \\
\text { None } \\
-17\end{array}$ & $\begin{array}{l}\text { Egert et al. } \\
(2009)[140]\end{array}$ \\
\hline
\end{tabular}




\begin{tabular}{|c|c|c|c|c|c|c|}
\hline $\begin{array}{l}M+F \text { aged } 18-29 y \\
M+F \text { aged } 45-69 y\end{array}$ & 6 & $\begin{array}{l}\text { Muffins incorporating } \\
\text { - ground flaxseed } \\
\text { - flaxseed oil } \\
\text { - ground flaxseeds } \\
\text { - flaxseed oil }\end{array}$ & 4 & $\begin{array}{l}\text { Total cholesterol } \\
\text { LDL-cholesterol } \\
\text { HDL-cholesterol } \\
\text { Triacylglycerol } \\
\text { Total cholesterol } \\
\text { LDL-cholesterol } \\
\text { HDL-cholesterol } \\
\text { Triacylglycerol } \\
\text { Total cholesterol } \\
\text { LDL-cholesterol } \\
\text { HDL-cholesterol } \\
\text { Triacylglycerol } \\
\text { Total cholesterol } \\
\text { LDL-cholesterol } \\
\text { HDL-cholesterol } \\
\text { Triacylglycerol }\end{array}$ & $\begin{array}{l}\text { None } \\
\text { None } \\
\text { None } \\
\text { None } \\
\text { None } \\
\text { None } \\
\text { None } \\
\text {-20 } \\
\text { None } \\
\text { None } \\
\text { None } \\
\text { None } \\
\text { None } \\
\text { None } \\
\text { None } \\
\text { None }\end{array}$ & $\begin{array}{l}\text { Patenaude et al. } \\
\text { (2009)[144] }\end{array}$ \\
\hline$M+F$ & 4.7 & Walnuts & 4 & $\begin{array}{l}\text { Total cholesterol } \\
\text { LDL-cholesterol } \\
\text { HDL-cholesterol } \\
\text { Triacylglycerol } \\
\text { Apo A } \\
\text { Apo B }\end{array}$ & $\begin{array}{l}-5 \\
-9 \\
\text { None } \\
\text { None } \\
\text { None } \\
-9\end{array}$ & $\begin{array}{l}\text { Rajaram et al. } \\
(2009)[164]\end{array}$ \\
\hline$M$ & 2.1 & Walnuts & 4 & $\begin{array}{l}\text { Total cholesterol } \\
\text { LDL-cholesterol } \\
\text { HDL-cholesterol }\end{array}$ & $\begin{array}{l}\text { None } \\
\text { None } \\
\text { None }\end{array}$ & $\begin{array}{l}\text { Din et al. } \\
(2011)[241]\end{array}$ \\
\hline
\end{tabular}




\begin{tabular}{|c|c|c|c|c|c|c|}
\hline & & & & Triacylglycerol & None & \\
\hline$M$ & 3.6 & Rapeseed oil and spread & 3 & $\begin{array}{l}\text { Total cholesterol } \\
\text { LDL-cholesterol } \\
\text { HDL-cholesterol } \\
\text { Triacylglycerol } \\
\text { Apo A } \\
\text { Apo B }\end{array}$ & $\begin{array}{l}\text { None } \\
\text { None } \\
\text { None } \\
\text { None } \\
+3 \\
\text { None }\end{array}$ & $\begin{array}{l}\text { Gladine et al. } \\
(2011)[242]\end{array}$ \\
\hline$M+F$ & $9.7^{*}$ & $\begin{array}{l}\text { Milled flaxseed added to } \\
\text { foods }\end{array}$ & 8 & $\begin{array}{l}\text { Total cholesterol } \\
\text { LDL-cholesterol } \\
\text { HDL-cholesterol } \\
\text { Triacylglycerol }\end{array}$ & $\begin{array}{l}-15 \\
-17 \\
+16 \\
-31\end{array}$ & $\begin{array}{l}\text { Khalatbari Soltani } \\
\text { et al. (2012)[244] }\end{array}$ \\
\hline$M+F$ & 8.7 & Organic Flaxseed oil & 6 & $\begin{array}{l}\text { Total cholesterol } \\
\text { LDL-cholesterol } \\
\text { HDL-cholesterol } \\
\text { Triacylglycerol }\end{array}$ & $\begin{array}{l}-5 \\
-7 \\
\text { None } \\
\text { None }\end{array}$ & $\begin{array}{l}\text { Kontogianni et al. } \\
\text { (2013)[163] }\end{array}$ \\
\hline$M+F$ & 0.5 & Cheese enriched with ALA & 3 & $\begin{array}{l}\text { Total cholesterol } \\
\text { LDL-cholesterol } \\
\text { HDL-cholesterol } \\
\text { Triacylglycerol }\end{array}$ & $\begin{array}{l}-5 \\
-7 \\
\text { None } \\
\text { None }\end{array}$ & $\begin{array}{l}\text { Pintus et al. } \\
(2013)[145]\end{array}$ \\
\hline$M+F$ & 7 & Flaxseed oil & 10 & Total cholesterol & -13 & Dittrich et al. \\
\hline
\end{tabular}




\begin{tabular}{|c|c|c|c|c|c|c|}
\hline & & & & $\begin{array}{l}\text { LDL-cholesterol } \\
\text { HDL-cholesterol } \\
\text { Triacylglycerol } \\
\text { Lipoprotein }\end{array}$ & $\begin{array}{l}-14 \\
\text { None } \\
\text { None } \\
\text { None }\end{array}$ & $(2014)[106]$ \\
\hline $\begin{array}{l}\text { M+F 20-35 y } \\
\text { M+F 49-69 y } \\
\text { M+F MetS }\end{array}$ & 5 & Echium oil & 8 & $\begin{array}{l}\text { Total cholesterol } \\
\text { LDL-cholesterol } \\
\text { HDL-cholesterol } \\
\text { Triacylglycerol } \\
\text { Total cholesterol } \\
\text { LDL-cholesterol } \\
\text { HDL-cholesterol } \\
\text { Triacylglycerol } \\
\text { Total cholesterol } \\
\text { LDL-cholesterol } \\
\text { HDL-cholesterol } \\
\text { Triacylglycerol }\end{array}$ & $\begin{array}{l}-6.2 \\
-9.6 \\
-8.7 \\
-12 \\
\text { None } \\
-4.8 \\
\text { None } \\
\text { None } \\
-8.2 \\
-11 \\
-6.8 \\
-11\end{array}$ & $\begin{array}{l}\text { Kuhnt et al. } \\
(2014)[107]\end{array}$ \\
\hline
\end{tabular}

M, male; F, female; Y, years; MetS, metabolic syndrome. *Approximate intake

Table 10. Studies investigating the effect of increased alpha-linolenic acid consumption on haemostatic factors in adult human subjects

\begin{tabular}{|l|c|c|c|c|l|l|}
\hline Subjects & $\begin{array}{c}\text { ALA } \\
\text { intake }\end{array}$ & ALA form & $\begin{array}{c}\text { Duration } \\
\text { (Weeks) }\end{array}$ & Outcomes investigated & Effect of ALA & Reference \\
\hline
\end{tabular}




\begin{tabular}{|c|c|c|c|c|c|c|}
\hline & $(g / d)$ & & & & & \\
\hline M & $20 *$ & Flaxseed oil & 8 & $\begin{array}{l}\text { Prothrombin time } \\
\text { Partial prothrombin time }\end{array}$ & $\begin{array}{l}\text { None } \\
\text { None }\end{array}$ & Kelley et al. (1993)[128] \\
\hline$M+F$ & 5.9 & Flaxseed oil & 4 & $\begin{array}{l}\text { Factor VII activity } \\
\text { PAI-I activity } \\
\text { Fibrinogen concentration } \\
\text { Anti-thrombin III activity }\end{array}$ & $\begin{array}{l}\text { None } \\
\text { None } \\
\text { None } \\
\text { None }\end{array}$ & Freese \& Mutanen (1997)[228] \\
\hline M & $3.7,15.4$ & $\begin{array}{l}\text { Flaxseed oil + } \\
\text { spread }\end{array}$ & 4 & $\begin{array}{l}\text { Factor VII concentration } \\
\text { Fibrinogen concentration } \\
\text { Prothrombin time } \\
\text { Anti-thrombin III activity } \\
\text { Plasminogen } \\
\text { concentration }\end{array}$ & $\begin{array}{l}\text { None } \\
\text { None } \\
\text { None } \\
\text { None } \\
\text { None }\end{array}$ & Li et al. (1999)[129] \\
\hline M & 3.5 & $\begin{array}{l}\text { Flaxseed oil + } \\
\text { flaxseed oil in } \\
\text { foods }\end{array}$ & 6 & $\begin{array}{l}\text { Factor VII concentration } \\
\text { Factor VII activity } \\
\text { Fibrinogen concentration } \\
\text { t-PA concentration } \\
\text { t-PA activity } \\
\text { PAl-1 concentration } \\
\text { PAl-1 activity }\end{array}$ & $\begin{array}{l}\text { None } \\
\text { None } \\
\text { None } \\
\text { None } \\
\text { None } \\
\text { None } \\
\text { None }\end{array}$ & $\begin{array}{l}\text { Allman-Farinelli et al. } \\
\text { (1999)[151] }\end{array}$ \\
\hline M & 4.2 & Perilla oil & 40 & $\begin{array}{l}\text { Fibrinogen concentration } \\
\text { PAl-1 concentration } \\
\text { Prothrombin time }\end{array}$ & $\begin{array}{l}\text { None } \\
\text { None } \\
\text { None }\end{array}$ & Ezaki et al (1999)[123] \\
\hline$M+F$ & 10 & $\begin{array}{l}\text { Spread }+ \text { foods } \\
\text { made with } \\
\text { rapeseed oil }\end{array}$ & 10 & $\begin{array}{l}\text { Factor II concentration } \\
\text { Factor VII concentration } \\
\text { Factor VII activity }\end{array}$ & $\begin{array}{l}\text { None } \\
\text { None } \\
\text { None }\end{array}$ & Junker et al. (2001)[235] \\
\hline
\end{tabular}




\begin{tabular}{|c|c|c|c|c|c|c|}
\hline & & & & $\begin{array}{l}\text { Factor } X \text { concentration } \\
\text { Factor XI concentration } \\
\text { Factor XII concentration } \\
\text { Factor XII activity } \\
\text { t-PA activity } \\
\text { PAI-1 activity } \\
\text { D-dimer concentration } \\
\text { Fibrinogen concentration }\end{array}$ & $\begin{array}{l}\text { None } \\
\text { None } \\
\text { None } \\
\text { None } \\
\text { None } \\
\text { None } \\
\text { None } \\
\text { None }\end{array}$ & \\
\hline$M+F$ & 6.3 & Spread & 10 & Fibrinogen concentration & $\begin{array}{l}\text { Decrease by } 0.18 \mathrm{~g} / \mathrm{l} \\
\text { compared with control } \\
\text { group }\end{array}$ & Bemelmans et al. (2002)[119] \\
\hline$M+F$ & 4.5 & $\begin{array}{l}\text { Spread } \\
\text { Spread }\end{array}$ & 24 & $\begin{array}{l}\text { Factor VII concentration } \\
\text { Factor XII concentration } \\
\text { Fibrinogen concentration } \\
\text { t-PA concentration } \\
\text { t-PA activity } \\
\text { PAI-1 concentration } \\
\text { PAI-1 activity } \\
\text { Factor VII concentration } \\
\text { Factor XII concentration } \\
\text { Fibrinogen concentration } \\
\text { t-PA concentration } \\
\text { t-PA activity } \\
\text { PAI-1 concentration } \\
\text { PAI-1 activity }\end{array}$ & $\begin{array}{l}\text { None } \\
\text { None } \\
\text { None } \\
\text { None } \\
\text { None } \\
\text { None } \\
\text { None } \\
\text { None } \\
\text { None } \\
\text { None } \\
\text { None } \\
\text { None } \\
\text { None } \\
\text { None }\end{array}$ & Finnegan et al. (2003)[234] \\
\hline $\mathrm{F}$ & 9 & Bread and & 48 & Fibrinogen concentration & None & Dodin et al. (2008)[139] \\
\hline
\end{tabular}




\begin{tabular}{|l|l|l|l|l|l|l|}
\hline & & $\begin{array}{l}\text { grains } \\
\text { incorporating } \\
\text { flaxseeds }\end{array}$ & & & \\
\hline $\mathrm{M}+\mathrm{F}$ & 3.4 & $\begin{array}{l}\text { Rapeseed oil }+ \\
\text { spread made } \\
\text { with rapeseed } \\
\text { oil }\end{array}$ & 24 & Fibrinogen concentration & None & Egert et al. (2014)[257] \\
\hline
\end{tabular}

M, male; F, female; PAI, plasminogen activator inhibitor; t-PA, tissue plasminogen activator. *Approximate intake 
Table 11. Studies investigating the effect of increased alpha-linolenic acid consumption on inflammatory markers in adult human subjects

\begin{tabular}{|c|c|c|c|c|c|c|}
\hline Subjects & $\begin{array}{c}\text { ALA } \\
\text { intake } \\
(\mathrm{g} / \mathrm{d})\end{array}$ & ALA form & $\begin{array}{l}\text { Duration } \\
\text { (Weeks) }\end{array}$ & Outcomes investigated & $\begin{array}{l}\text { Effect of ALA } \\
\text { (\% change } \\
\text { where } \\
\text { significant) }\end{array}$ & Reference \\
\hline$M$ & 13.7 & Flaxseed oil + spread & 4 & $\begin{array}{l}\text { Production of prostaglandin } \mathrm{E}_{2} \text { by } \\
\text { PBMC } \\
\text { Production of TNF- } \alpha \text { by PBMC } \\
\text { Production of IL- } 1 \beta \text { by PBMC }\end{array}$ & $\begin{array}{l}-33 \% \\
-27 \% \\
-30 \%\end{array}$ & $\begin{array}{l}\text { Caughey et al. } \\
\text { (1996)[152] }\end{array}$ \\
\hline $\mathrm{M}+\mathrm{F}$ & 10 & $\begin{array}{l}\text { Spread + foods made with } \\
\text { rapeseed oil }\end{array}$ & 4 & $\begin{array}{l}\text { Serum concentration of CRP } \\
\text { Serum concentration of sL-selectin }\end{array}$ & $\begin{array}{l}\text { None } \\
\text { None }\end{array}$ & $\begin{array}{l}\text { Junker et al. } \\
\text { (2001)[235] }\end{array}$ \\
\hline $\mathrm{M}+\mathrm{F}$ & 2 & Flaxseed oil capsules & 12 & $\begin{array}{l}\text { Neutrophil respiratory burst } \\
\text { Monocyte respiratory burst } \\
\text { Production of TNF- } \alpha \text { by PBMC } \\
\text { Production of IL-1 } \beta \text { by PBMC } \\
\text { Production of IL- } 6 \text { by PBMC } \\
\text { Plasma concentrations of sVCAM-1, } \\
\text { sICAM-1, and sE-selectin }\end{array}$ & $\begin{array}{l}\text { None } \\
\text { None } \\
\text { None } \\
\text { None } \\
\text { None } \\
\text { None }\end{array}$ & $\begin{array}{l}\text { Thies et al. } \\
(2001)[262]\end{array}$ \\
\hline $\mathrm{M}+\mathrm{F}$ & 4.5 & $\begin{array}{l}\text { Spread } \\
\text { Spread }\end{array}$ & $x^{2}$ & $\begin{array}{l}\text { Neutrophil respiratory burst } \\
\text { Monocyte respiratory burst } \\
\text { Production of TNF- } \alpha \text { by PBMC } \\
\text { Production of IL- } 1 \beta \text { by PBMC } \\
\text { Production of IL- } 6 \text { by PBMC } \\
\text { Neutrophil respiratory burst }\end{array}$ & $\begin{array}{l}\text { None } \\
\text { None } \\
\text { None } \\
\text { None } \\
\text { None } \\
\text { None }\end{array}$ & $\begin{array}{l}\text { Kew et al. } \\
(2003)[154]\end{array}$ \\
\hline
\end{tabular}




\begin{tabular}{|c|c|c|c|c|c|c|}
\hline & & & & $\begin{array}{l}\text { Monocyte respiratory burst } \\
\text { Production of TNF- } \alpha \text { by PBMC } \\
\text { Production of IL-1 } 1 \beta \text { by PBMC } \\
\text { Production of IL- } 6 \text { by PBMC }\end{array}$ & $\begin{array}{l}\text { None } \\
\text { None } \\
\text { None } \\
\text { None }\end{array}$ & \\
\hline M & 4.7 & Flaxseed oil capsules & 12 & $\begin{array}{l}\text { Production of TNF- } \alpha \text { by PBMC } \\
\text { Production of IL- } 1 \beta \text { by PBMC } \\
\text { Production of IL- } 6 \text { by PBMC }\end{array}$ & $\begin{array}{l}\text { None } \\
\text { None } \\
\text { None }\end{array}$ & $\begin{array}{l}\text { Wallace et al. } \\
(2003)[132]\end{array}$ \\
\hline M & 8 & Flaxseed oil & 12 & $\begin{array}{l}\text { Serum concentrations of CRP, SAA } \\
\text { and IL- } 6 \\
\text { Serum concentration of sVCAM-1 } \\
\text { Serum concentrations of SICAM-1 } \\
\text { and sE-selectin }\end{array}$ & $\begin{array}{l}\text { All }-25 \% \\
-15 \% \\
\text { None }\end{array}$ & $\begin{array}{l}\text { Rallidis et al. } \\
(2003,2004)[240, \\
263]\end{array}$ \\
\hline$M+F$ & 6.3 & Spread & 52 and 104 & $\begin{array}{l}\text { Serum concentration of CRP } \\
\text { Serum concentrations of sICAM-1, IL- } \\
6 \text { and IL-10 }\end{array}$ & $\begin{array}{l}-12.5 \% \\
\text { None }\end{array}$ & $\begin{array}{l}\text { Bemelmans et } \\
\text { al. (2004)[261] }\end{array}$ \\
\hline $\mathrm{F}$ & 9 & $\begin{array}{l}\text { Bread and grains } \\
\text { incorporating flaxseeds }\end{array}$ & 48 & Plasma concentration of CRP & None & $\begin{array}{l}\text { Dodin et al. } \\
(2008)[139]\end{array}$ \\
\hline
\end{tabular}




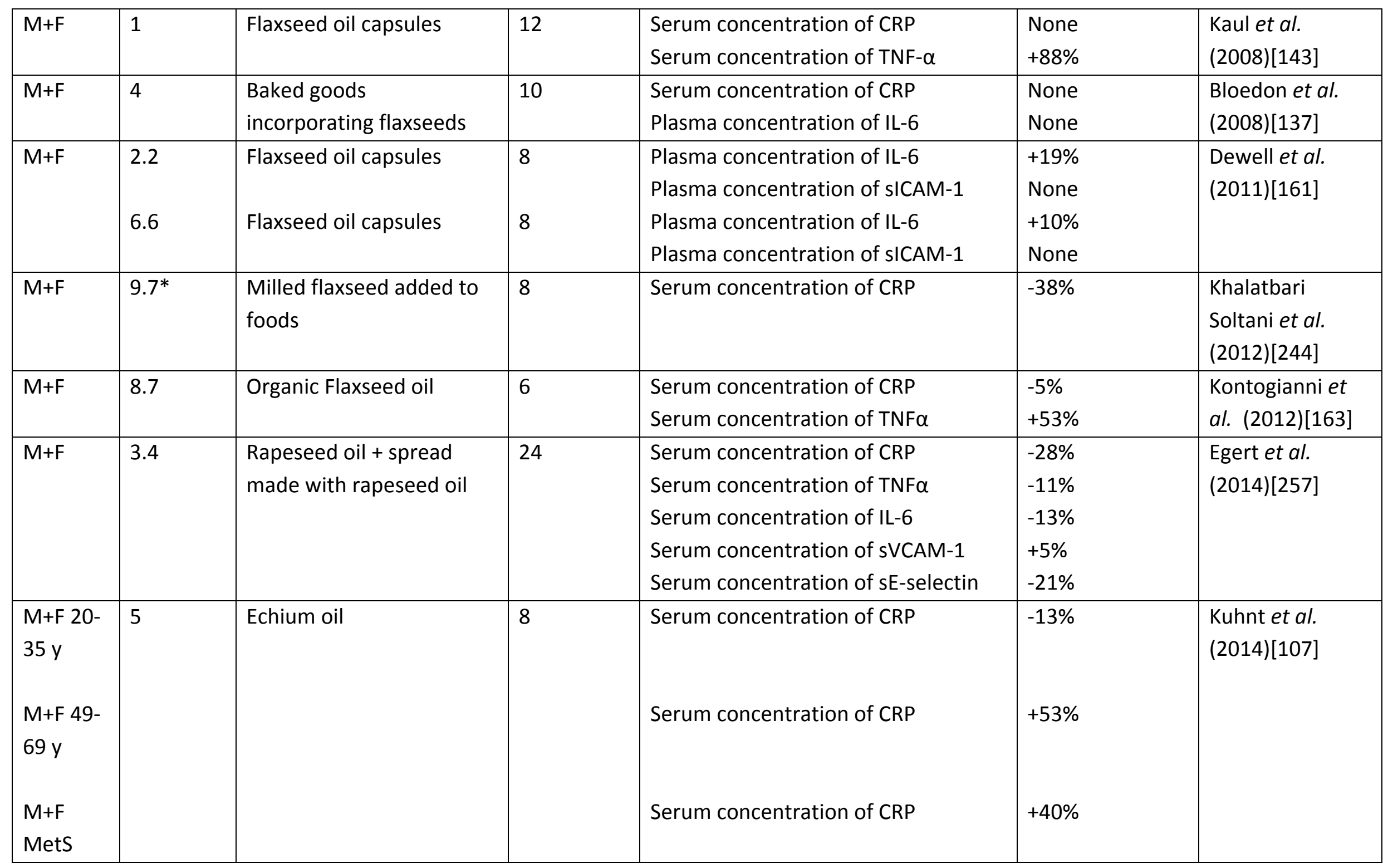




\begin{tabular}{|l|l|l|l|l|l|l|}
\hline & & & & \\
\hline $\mathrm{M}+\mathrm{F}$ & 3 & $\begin{array}{l}\text { Sesame/pumpkin/flaxseed } \\
\text { mix }\end{array}$ & 12 & $\begin{array}{l}\text { Serum concentration of CRP } \\
\text { Serum concentration of TNF } \alpha \\
\text { Serum concentration of IL-6 }\end{array}$ & $\begin{array}{l}-61 \% \\
-79 \%\end{array}$ & -51\% \\
\hline
\end{tabular}

M, male; F, female; PBMC, peripheral blood mononuclear cells; CRP, C-reactive protein; sVCAM, soluble vascular cell adhesion molecule; sICAM, soluble intercellular adhesion molecule, sE-selectin, soluble E-selectin; SAA, serum amyloid A *Approximate intake 
Table 12. Controlled intervention studies in human subjects investigating the effect of increased alpha-linolenic acid consumption on immune function, other than inflammation, in adult human subjects.

\begin{tabular}{|c|c|c|c|c|c|c|}
\hline Subjects & $\begin{array}{c}\text { ALA intake } \\
(\mathrm{g} / \mathrm{d})\end{array}$ & ALA form & $\begin{array}{l}\text { Duration } \\
\text { (Weeks) }\end{array}$ & Outcomes investigated & Effects of ALA & Reference \\
\hline M & 20 & Flaxseed oil & 8 & $\begin{array}{l}\text { Serum concentrations of IgG, } \\
\text { IgA and complement C } 3 \text { and } \\
\text { C4 } \\
\text { Saliva concentration of SIgA } \\
\text { B cell proliferation } \\
\text { T cell proliferation } \\
\text { Production of IL-2 and SIL-2 } \\
\text { receptor by PBMC } \\
\text { DTH response }\end{array}$ & $\begin{array}{l}\text { None } \\
\text { None } \\
\text { None } \\
\text { Decrease with some } \\
\text { mitogens } \\
\text { Decrease by } 23 \% \\
\text { None }\end{array}$ & $\begin{array}{l}\text { Kelley et al. } \\
\text { (1991)[265] }\end{array}$ \\
\hline$M+F$ & 2 & $\begin{array}{l}\text { Flaxseed oil } \\
\text { capsules }\end{array}$ & 12 & $\begin{array}{l}\text { Neutrophil phagocytosis } \\
\text { Monocyte phagocytosis } \\
\text { T cell proliferation } \\
\text { Production of IL-2, IFN- } \gamma \text { and } \\
\text { IL-4 by PBMC } \\
\text { NK cell activity }\end{array}$ & $\begin{array}{l}\text { None } \\
\text { None } \\
\text { None } \\
\text { None } \\
\text { None }\end{array}$ & $\begin{array}{l}\text { Thies et al. } \\
(2001)[262, \\
266,267]\end{array}$ \\
\hline$M+F$ & 4.5 & $\begin{array}{l}\text { Spread } \\
\text { Spread }\end{array}$ & $\begin{array}{l}24 \\
24 \\
\end{array}$ & $\begin{array}{l}\text { Neutrophil phagocytosis } \\
\text { Monocyte phagocytosis } \\
\text { T cell proliferation } \\
\text { Production of IL-2, IFN- } \gamma \text { and } \\
\text { IL-4 by PBMC } \\
\text { DTH response } \\
\text { Neutrophil phagocytosis }\end{array}$ & $\begin{array}{l}\text { None } \\
\text { None } \\
\text { None } \\
\text { None } \\
\text { None } \\
\text { None }\end{array}$ & $\begin{array}{l}\text { Kew et al. } \\
\text { (2003)[154] }\end{array}$ \\
\hline
\end{tabular}




\begin{tabular}{|l|l|l|l|l|l|l|}
\hline & & & & $\begin{array}{l}\text { Monocyte phagocytosis } \\
\text { T cell proliferation } \\
\text { Production of IL-2, IFN- } \gamma \text { and } \\
\text { IL-4 by PBMC } \\
\text { DTH response }\end{array}$ & $\begin{array}{l}\text { None } \\
\text { None } \\
\text { None }\end{array}$ \\
\hline $\mathrm{M}$ & 4.7 & $\begin{array}{l}\text { Flaxseed oil } \\
\text { capsules }\end{array}$ & 12 & $\begin{array}{l}\text { T cell proliferation } \\
\text { Production of IL-2, IFN- } \gamma, \text { IL-4 } \\
\text { and IL-10 by PBMC }\end{array}$ & $\begin{array}{l}\text { None } \\
\text { None }\end{array}$ & $\begin{array}{l}\text { Wallace } \text { et al. } \\
(2003)[132]\end{array}$ \\
\hline
\end{tabular}

M, male; F, female; PBMC, peripheral blood mononuclear cells; SIgA, secretory IgA; DTH, delayed type hypersensitivity; IFN, interferon; NK, natural killer *Approximate intake 